\title{
Determining Discharge-Coefficient Ratings for Coastal Structures in Dade County, Florida
}

By ERIC D. SWAIN, AMIT KAPADIA, SIAKA KONÉ, EMILE DAMISSE, DAVIES MTUNDU, and GINA M. TILLIS

\section{U.S. GEOLOGICAL SURVEY}

Water-Resources Investigations Report 97-4079

Prepared in cooperation with the

South Florida Water Management District

as part of the U.S. Geological Survey South Florida

Ecosystem Program

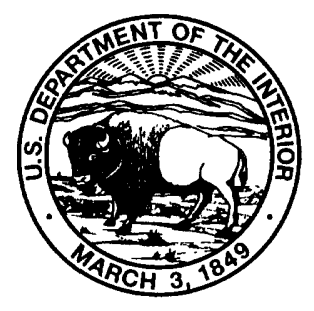




\title{
U.S. DEPARTMENT OF THE INTERIOR BRUCE BABBITT, Secretary
}

\author{
U.S. GEOLOGICAL SURVEY \\ Gordon P. Eaton, Director
}

The use of firm, trade, and brand names in this report is for identification purposes only and does not constitute endorsement by the U.S. Geological Survey.

For additional information write to:

District Chief

U.S. Geological Survey

Suite 3015

227 North Bronough St.

Tallahassee, FL 32301
Copies of this report can be purchased from:

U.S. Geological Survey

Branch of Information Services

Box 25286

Denver, CO 80225 


\section{CONTENTS}

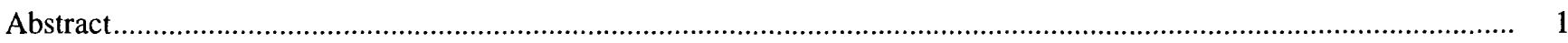

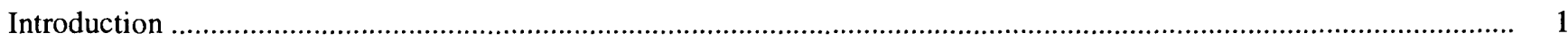

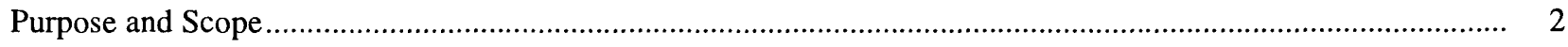

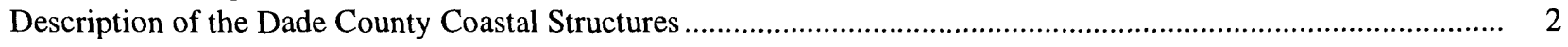

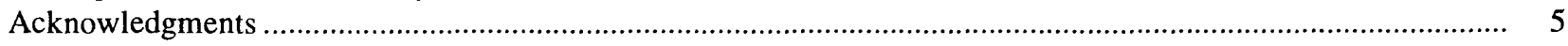

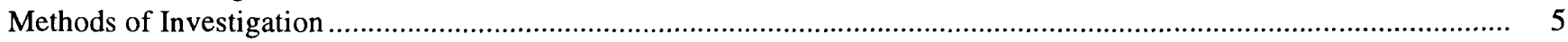

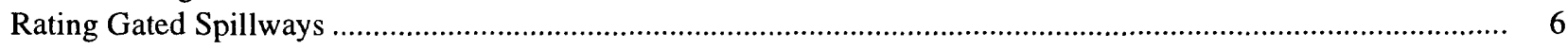

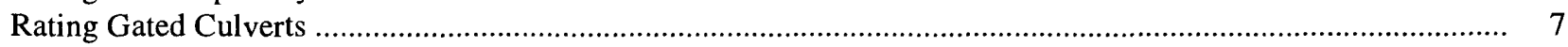

Acoustic Doppler Techniques...................................................................................................................... 8

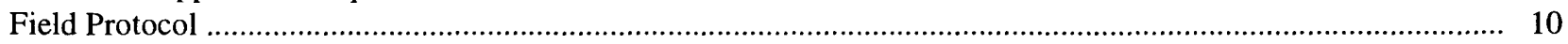

Discharge-Coefficient Ratings for the Dade County Coastal Structures ........................................................................ 11

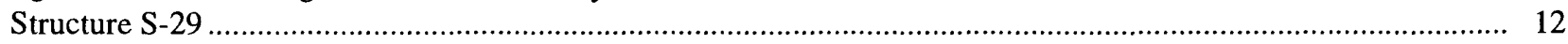

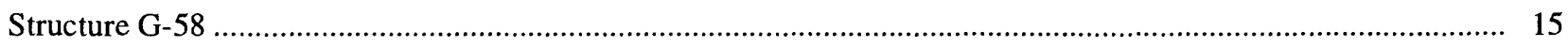

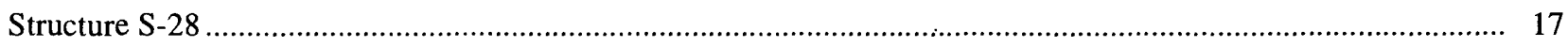

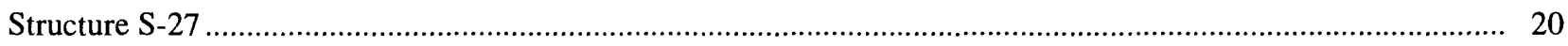

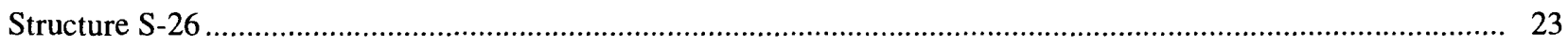

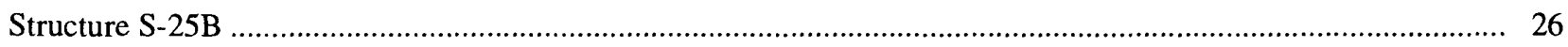

Structure S-25

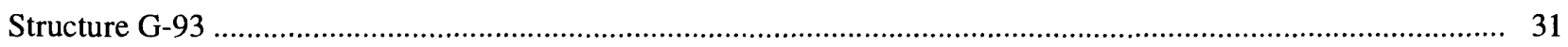

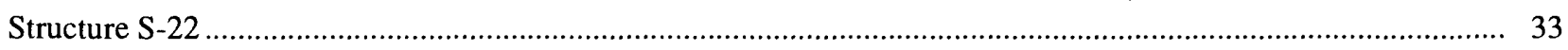

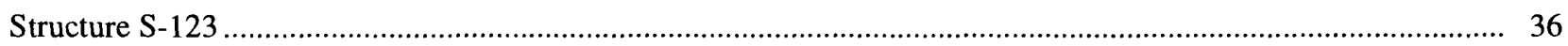

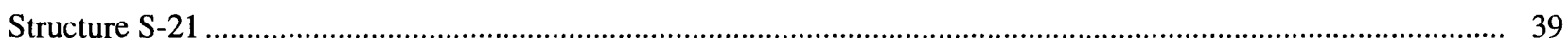

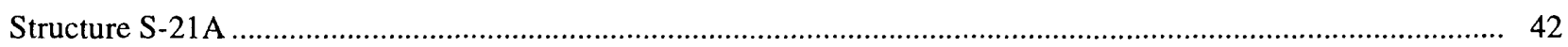

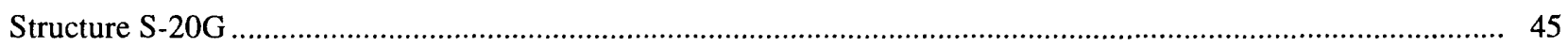

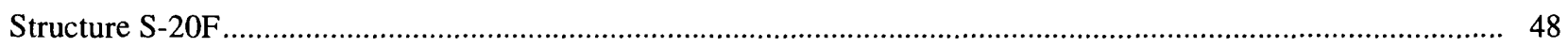

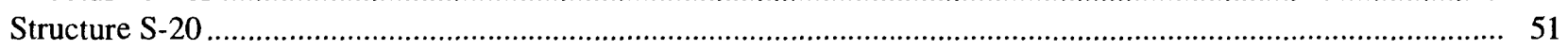

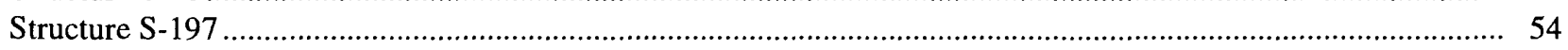

Summary and Evaluation of Discharge-Coefficient Ratings..................................................................................... 55

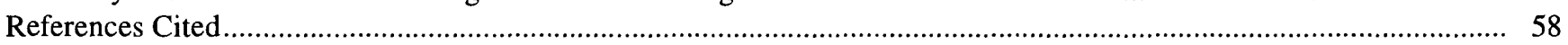

Appendix I. Flood Discharge Characteristics for the Dade County Coastal Structures ....................................................... 59

Appendix II. Structural Dimensions (Data) for the Dade County Coastal Structures..................................................... 60

Appendix III. Glossary of Mathematical Symbols Used in Report......................................................................... 61

\section{FIGURES}

1. Map showing coastal control structures in eastern Dade County ……………………………………………..... 3

2. Schematic showing flow regimes for a gated spillway ................................................................................. 6

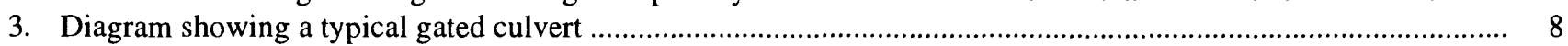

4. Schematic showing signal path of an Acoustic Doppler Current Profiler ................................................................. $\quad 9$

5. Aerial photograph showing typical field setup for an Acoustic Doppler Current Profiler measurement of streamflow.

6. Aerial photograph showing structure S-29

7. Graphs showing logarithmic plot of the S-29 discharge coefficient for submerged orifice flow and linear scale plots of a comparison of the S-29 discharge coefficient for submerged orifice flow and submerged weir flow ........ 13

8. Graph showing theoretical and computed flows for structure S-29 in 1994 ......................................................... 14

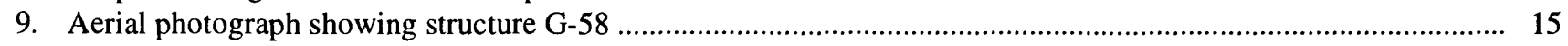

10. Graph showing linear scale plot of the discharge coefficient for the G-58 gated culvert........................................ 16

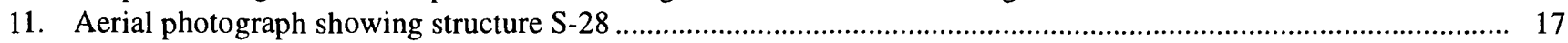


12. Graphs showing logarithmic plot of the S-28 discharge coefficient for submerged orifice flow and linear scale plots of a comparison of the S-28 discharge coefficient for submerged orifice flow and submerged weir flow.......

13. Graph showing theoretical and computed flows for structure S-28 in 1994.

14. Aerial photograph showing structure $S-27$

15. Graphs showing logarithmic plot of the S-27 discharge coefficient for submerged orifice flow and linear scale plots of a comparison of the S-27 discharge coefficient for submerged orifice flow and submerged weir flow...

16. Graph showing theoretical and computed flows for structure S-27 in 1994.

17. Aerial photograph showing structure S-26.

18. Graphs showing logarithmic plot of the S-26 discharge coefficient for submerged orifice flow and linear scale plots of a comparison of the S-26 discharge coefficient for submerged orifice flow and submerged weir flow.........

19. Graph showing theoretical and computed flows for structure S-26 in 1994.

20. Aerial photograph showing structure S-25B

21. Graphs showing logarithmic plot of the S-25B discharge coefficient for submerged orifice flow and linear scale plots of a comparison of the S-25B discharge coefficient for submerged orifice flow and submerged weir flow.

22. Graph showing theoretical and computed flows for structure S-25B in 1994

23. Aerial photograph showing structure $\mathrm{S}-25$.

24. Graphs showing linear scale plot of the discharge coefficient for the S-25 gated culvert ...

25. Aerial photograph showing structure G-93...

26. Graphs showing logarithmic plot of the G-93 discharge coefficient for submerged orifice flow and linear scale plots of a comparison of the G-93 discharge coefficient for submerged orifice flow and submerged weir flow .......

27. Aerial photograph showing structure S-22.

28. Graphs showing logarithmic plot of the S-22 discharge coefficient for submerged orifice flow and linear scale plots of a comparison of the S-22 discharge coefficient for submerged orifice flow and submerged weir flow........

29. Graph showing theoretical and computed flows for structure S-22 in 1994

30. Aerial photograph showing structure S-123.

31. Graphs showing logarithmic plot of the S-123 discharge coefficient for submerged orifice flow and linear scale plots of a comparison of the S-123 discharge coefficient for submerged orifice flow and submerged weir flow.

32. Graph showing theoretical and computed flows for structure S-123 in 1994 .

33. Aerial photograph showing structure $\mathrm{S}-21$.

34. Graphs showing logarithmic plot of the S-21 discharge coefficient for submerged orifice flow and linear scale plots of a comparison of the S-21 discharge coefficient for submerged orifice flow and submerged weir flow...

35. Graph showing theoretical and computed flows for structure S-21 in 1994.

36. Aerial photograph showing structure S-21A

37. Graphs showing logarithmic plot of the S-21A discharge coefficient for submerged orifice flow and linear scale plots of a comparison of the S-21A discharge coefficient for submerged orifice flow and submerged weir flow

38. Graph showing theoretical and computed flows for structure S-21A in 1994

39. Aerial photograph showing structure S-20G

40. Graphs showing logarithmic plot of the S-20G discharge coefficient for submerged orifice flow and linear scale plots of a comparison of the S-20G discharge coefficient for submerged orifice flow and submerged weir flow

41. Graph showing theoretical and computed flows for structure S-20G in 1994

42. Aerial photograph showing structure S-20F

43. Graphs showing logarithmic plot of the S-20F discharge coefficient for submerged orifice flow and linear scale plots of a comparison of the S-20F discharge coefficient for submerged orifice flow and submerged weir flow.

44. Graph showing theoretical and computed flows for structure S-20F in 1994.

45. Aerial photograph showing structure $S-20 \ldots$

46. Graphs showing logarithmic plot of the S-20 discharge coefficient for submerged orifice flow and linear scale plots of a comparison of the S-20 discharge coefficient for submerged orifice flow and submerged weir flow........

47. Graph showing theoretical and computed flows for structure S-20 in $1994 \ldots$

48. Aerial photograph showing structure S-197

49. Graph showing linear scale plot of the discharge coefficient for the S-197 gated culvert.....

50. Pie charts showing cumulative theoretical and computed flows for 1994 ..... 


\section{TABLES}

1. Types and rating status of coastal structures in Dade County prior to study

2. Dates of measurement

3. Summary of discharge-coefficient ratings... 


\title{
Determining Discharge-Coefficient Ratings for Coastal Structures in Dade County, Florida
}

\author{
By Eric D. Swain, Amit Kapadia, Siaka Koné, Emile Damisse, Davies Mtundu, and Gina M. Tillis
}

\section{ABSTRACT}

The flows through the 16 coastal structures in Dade County, Fla., are presently computed by theoretical discharge-coefficient ratings developed from scale modeling and theoretical flow coefficients, whose accuracies for specific sites are unknown. To create more accurate discharge-coefficient ratings for the coastal structures, field measurements were taken with an Acoustic Doppler Current Profiler at each coastal structure under a variety of structure operations. The Acoustic Doppler Current Profiler is capable of measuring low and rapidly varying flows that occur at the coastal structures. The field measurements were used to develop computed discharge-coefficient ratings for the coastal structures under different flow regimes: submerged weir flow, submerged orifice flow, free weir flow, and free orifice flow. Additionally, flow hydrographs, using both the theoretical- and computed-coefficient ratings, were plotted for most of the coastal structures.

The difference between the theoretical- and computed-coefficient ratings varied from structure to structure. The theoretical- and computed-coefficient ratings for submerged orifice flow were within 10 percent at structures S-22, S-25B, S-26, S-27, S-28, and S-123; however, marked differences ( 25 percent or greater) were seen at structures S-20F and S-21. The theoretical- and computed-coefficient ratings for submerged weir flow were within 10 percent at structures G-93, S-20F, S-27, S-29, and S-123; however, marked differences ( 25 percent or greater) were seen at structures S-20, S-20G, S-21, S-21A, S-25B, and
S-28. The closest match to the theoretical-coefficient rating was at structure S-123, and the worst match to the theoretical-coefficient rating was at structure S-21. The significant differences between the theoretical-and computed-coefficient ratings could be a result of basing the ratings on 30 or fewer data points.

\section{INTRODUCTION}

The hydrologic system of southern Florida has been subjected to extensive alteration by man. A system of canals and levees has been constructed over the last century for the purpose of draining the wetlands and for flood control. Strategically placed control structures allow water-management operators to drain water during high rainfall periods and to retain water during the dry periods. Starting in the 1920's, water issues other than flood control in southern Florida became prominent. These issues included the effects of lowered water levels caused by overdrainage (such as lowered surface- and ground-water levels), droughts, frequency of dry-season fires in the wetlands, and saltwater intrusion in coastal areas. To address these concerns, hydraulic (control) structures were added to the system, regulating flows through the system and to the east coast. By the late 1960's, most of the complex system of canals, levees, pumping stations, and salinitycontrol structures was completed. Although the system has made southern Florida more suitable for urbanization and agriculture, problems of periodic droughts and saltwater intrusion persist.

One of the predominant factors driving the development of southern Florida water controls is the rapid population growth along the lower east coast. Ground-water withdrawals from the Biscayne aquifer 
for public supply are threatened by saltwater intrusion induced by the lowering of ground-water levels inland. The use of surface water to replace the aquifer losses means that less water is available for the wetlands in the Everglades and other areas. The salinity-control structures along the coast in eastern Dade County (fig. 1), referred to herein as coastal structures, are used to maintain higher water levels upstream to prevent saltwater intrusion. The higher surface-water levels induce higher ground-water levels, which prevent saltwater movement through the aquifer inland. Excess stormwater is also drained through these coastal structures. These freshwater discharges not only affect the amount of water available to the wetland areas and for water supply in the lower east coast, but also adversely affect the biota in Biscayne Bay (Browder and others, 1989).

Quantifying these freshwater discharges to the east coast is an important component in computing accurate water budgets for the inland and wetland areas, calibration and use of regional water- management models, and computation of nutrient loadings to Biscayne Bay. In eastern Dade County, 14 of the 16 coastal structures have never been measured for flow; instead, discharges have been computed from manual readings of gate openings and stages and application of theoretical flow coefficients by the South Florida Water Management District (SFWMD) and the U.S. Army Corps of Engineers (COE). In order to ensure that data for the flows through these coastal structures are accurate, flow measurements must be used to calibrate the coastal structures. This requires accurate measurements of discharges through the coastal structure, data on structure operations, and headwater and tailwater elevations. These measurements must be taken under a variety of conditions to encompass all the flow regimes occurring at each coastal structure.

The U.S. Geological Survey (USGS) began a study in 1994 to develop a technique of measuring freshwater flows through coastal structures and to develop discharge-coefficient ratings for these coastal structures, as part of its South Florida Ecosystem Program in cooperation with the SFWMD. The South Florida Ecosystem Program is a collaborative effort by the USGS working with other Federal, State, and local agencies and Indian Tribes to provide earth science information needed to resolve land-use demands and water issues in southern Florida. This report presents the results of the Dade County study for determining discharge-coefficient ratings. A similar study was conducted in Broward and Palm Beach Counties (G.M.
Tillis and E.D. Swain, U.S. Geological Survey, written commun., 1997).

\section{Purpose and Scope}

This report presents a technique for determining discharge-coefficient ratings for coastal structures in Dade County, Fla. These coefficient ratings test the accuracy of discharge determined by theoretical methods and allow more accurate determination of the total amount of water being discharged. The techniques developed can be applied to other locations.

Sixteen coastal structure ouflows in eastern Dade County were measured, and discharge-coefficient ratings were developed from these data. Discharge measurements were taken under a variety of conditions to develop the computed-coefficient ratings, and comparisons were made to the theoretical-coefficient ratings. All concurrent water-level, gate opening, and discharge data were collated and analyzed using a spreadsheet program. Flow regimes were identified, and a least squares fit was used to determine the best estimate of the appropriate coefficients. Uncertainty in the coefficient values was determined from the error in fit of the field data. Results of these analyses are presented herein.

\section{Description of the Dade County Coastal Structures}

This section describes the 16 coastal structures located in eastern Dade County (fig. 1). Of the 16 coastal structures, 13 structures are gated spillways and 3 structures are gated culverts. The rating status for each coastal structure is presented in table 1 .

The northernmost and easternmost coastal structure is gated spillway S-29 (fig. 1) located on the C-9 canal, which drains an area of about $98 \mathrm{mi}^{2}$ (square miles). This area was subject to flooding prior to canal construction, and overdrainage resulted after the construction of the canal. Structure S-29 was constructed to replace salinity-control dams, which had been placed as a temporary measure to prevent saltwater intrusion (Kohout and Leach, 1964). A similar hydrologic situation existed in the C-8 canal to the south of the C-9 canal. A sheet-pile weir, placed in the C-8 canal to maintain a higher upstream water level, was replaced by structure $S-28$ (fig. 1). This coastal structure, $2 \mathrm{mi}$ (miles) downstream of the weir, allowed more control 


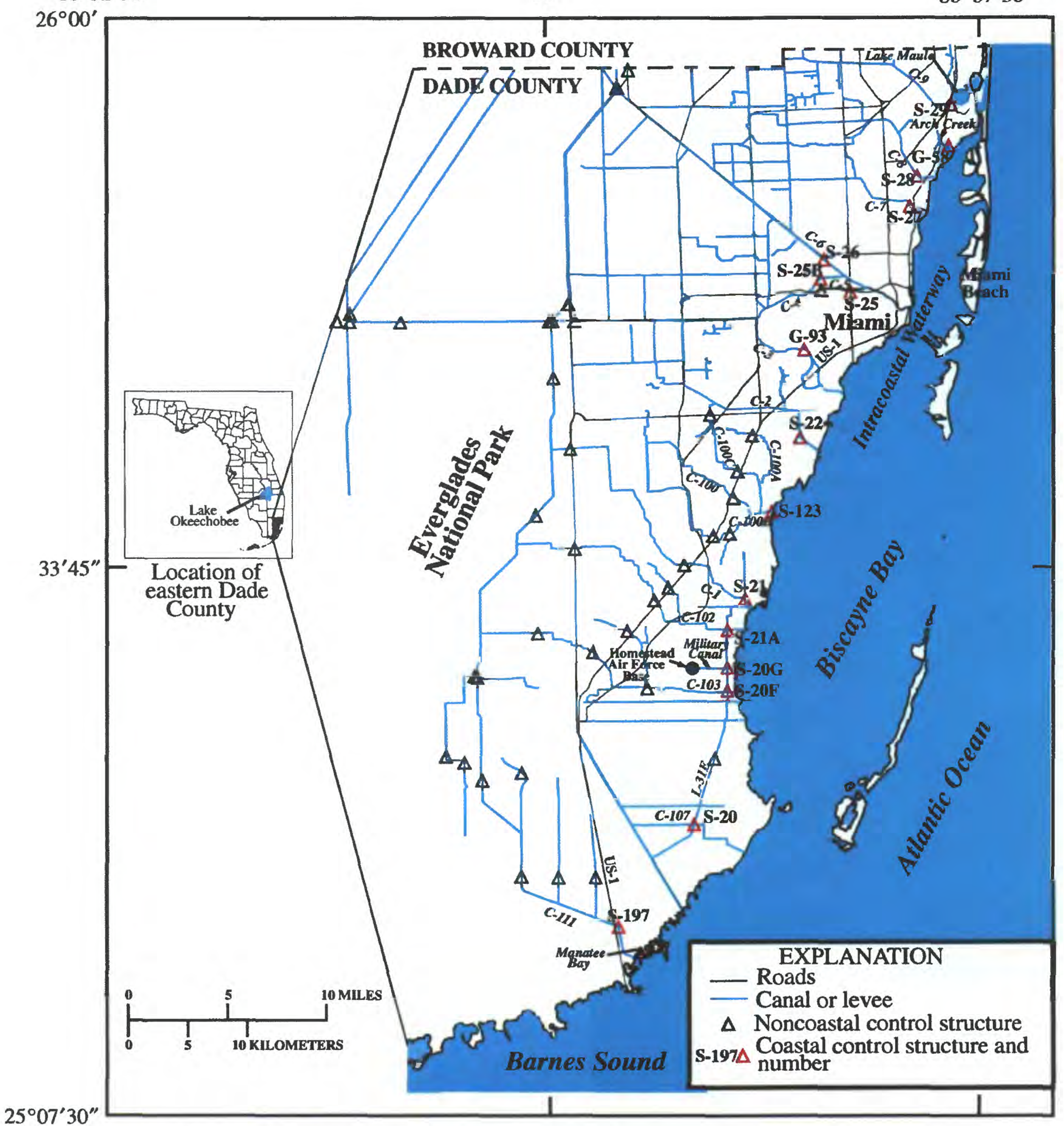

Figure 1. Coastal control structures in eastern Dade County. 
Table 1. Types and rating status of coastal structures in Dade County prior to study

[Locations of structures are shown in figure 1; Structure type: GC, gated culvert; GS, gated spillway;

USGS, U.S. Geological Survey]

\begin{tabular}{|c|c|c|c|}
\hline $\begin{array}{l}\text { Structure } \\
\text { number }\end{array}$ & Location & $\begin{array}{l}\text { Structure } \\
\text { type }\end{array}$ & Rating status prior to study \\
\hline G-58 & $\begin{array}{l}\text { Miami; on Arch Creek immediately down- } \\
\text { stream from the Florida East Coast Railroad } \\
\text { Bridge in the bridge abutment of N.E. 135th } \\
\text { Street }\end{array}$ & GC & Theoretical \\
\hline G-93 & Miami; on the C- 3 canal at Red Road & GS & Theoretical \\
\hline S-20 & $\begin{array}{l}\text { Miami; on the C-107 canal; about } 3 \text { miles } \\
\text { from Biscayne Bay }\end{array}$ & GS & Theoretical \\
\hline S-20F & $\begin{array}{l}\text { Miami; near the mouth of the C- } 103 \text { canal at } \\
\text { its junction with the L-31E canal; about } \\
2,000 \text { feet from Biscayne Bay }\end{array}$ & GS & Previous USGS rating not verified \\
\hline S-20G & $\begin{array}{l}\text { Miami; near the mouth of the Military Canal } \\
\text { at its junction with the L-31E canal }\end{array}$ & GS & Theoretical \\
\hline S-21 & $\begin{array}{l}\text { Miami; near the mouth of the C-1 canal at } \\
\text { its junction with the L- } 31 \mathrm{E} \text { canal; about } \\
3,500 \text { feet from Biscayne Bay }\end{array}$ & GS & $\begin{array}{l}\text { Discharge measurements made for } \\
\text { calibration }\end{array}$ \\
\hline S-21A & $\begin{array}{l}\text { Miami; near the mouth of the C-102 canal at } \\
\text { its junction with the L-31E canal; about } 1 \\
\text { mile from Biscayne Bay }\end{array}$ & GS & Theoretical \\
\hline S-22 & $\begin{array}{l}\text { Miami; near the mouth of the } \mathrm{C}-2 \text { canal; } \\
\text { about } 1.3 \text { miles from Biscayne Bay }\end{array}$ & GS & Theoretical \\
\hline S-25 & $\begin{array}{l}\text { Miami; at the N.W. 27th Avenue crossing of } \\
\text { the C-5 canal }\end{array}$ & GC & Theoretical \\
\hline $\mathrm{S}-25 \mathrm{~B}$ & $\begin{array}{l}\text { Miami; immediately downstream of the Le } \\
\text { Jeune Road crossing of the C- } 4 \text { canal }\end{array}$ & GS & Theoretical \\
\hline S-26 & $\begin{array}{l}\text { Miami; at the N.W. 36th Street crossing of } \\
\text { the C- } 6 \text { canal }\end{array}$ & GS & $\begin{array}{l}\text { Discharge measurements made for } \\
\text { calibration }\end{array}$ \\
\hline S-27 & $\begin{array}{l}\text { Miami; near the mouth of the } \mathrm{C}-7 \text { canal; } \\
\text { about } 1.3 \text { miles from Biscayne Bay }\end{array}$ & GS & Theoretical \\
\hline S-28 & $\begin{array}{l}\text { Miami; near the mouth of the C- } 8 \text { canal; } \\
\text { about } 1 \text { mile from Biscayne Bay }\end{array}$ & GS & Theoretical \\
\hline S-29 & $\begin{array}{l}\text { North Miami Beach; near the mouth of the } \\
\text { C- } 9 \text { canal; about } 500 \text { feet from Lake Maule }\end{array}$ & GS & Theoretical \\
\hline S-123 & $\begin{array}{l}\text { Miami; near the mouth of the C-100 canal } \\
\text { below the junction of the C-100, C-100A, } \\
\text { and C-100B canals; about } 600 \text { feet from } \\
\text { Biscayne Bay }\end{array}$ & GS & Theoretical \\
\hline S-197 & $\begin{array}{l}\text { Miami; near the mouth of the C-111 canal; } \\
\text { about } 3 \text { miles from Manatee Bay and } 750 \\
\text { feet east of U.S. Highway } 1\end{array}$ & GC & Theoretical \\
\hline
\end{tabular}


of flow to the ocean. Structure S-28 is the only coastal structure that regulates flow from this $31.5 \mathrm{mi}^{2}$ drainage area (Cooper and Lane, 1987).

Structure G-58 (fig. 1) is a set of gated culverts, located south of structure S-29 and north of structure S-28, which controls flow from Arch Creek to the Atlantic Ocean. Arch Creek does not connect to any upstream canals and drains a $4-\mathrm{mi}^{2}$ area. This coastal structure was constructed to control flooding in a nearby park and urban area (U.S. Army Corps of Engineers, 1995).

An original sheet-pile weir in the C-7 canal was replaced by structure $S-27$ (fig. 1) located $1 \mathrm{mi}$ farther downstream. The function of structure S-27 was to raise water levels upstream, but drainage problems resulted in surrounding residential areas. A pump station was used to alleviate this problem. Since the construction of structure S-27, residential development has made flood protection even more crucial in this $35-\mathrm{mi}^{2}$ area.

Structures S-26, S-25B, and S-25 (fig. 1) control salinity intrusion by maintaining higher upstream water levels relative to downstream water levels. Additionally, structure S-26 controls water levels in the large C-6 canal and regulates discharge to tidewater. The C- 6 canal was originally constructed as a drainage outlet from Lake Okeechobee. Structure S-25B on the C-4 canal regulates discharge into the C-6 canal (from C-4) downstream of structure S-26. Structure S-25, a gated culvert on the small C-5 canal, also controls discharge to the C-6 canal (from C-5).

An original sheet-pile weir in the C-3 canal was replaced in 1988 by structure G-93 (fig. 1) located farther inland than many of the other coastal structures in eastern Dade County. This manually operated coastal structure maintains upstream water levels to prevent saltwater intrusion.

Structure S-22 (fig. 1) was constructed in 1946 to control flows from the $\mathrm{C}-2$ canal, which drains an area of about $53 \mathrm{mi}^{2}$. However, the flood-control capabilities of structure S-22 may not be presently adequate because of substantial urban development since the design and construction of S-22 and the enlargement of the C-2 canal.

Structure S-123 (fig. 1) was constructed to regulate discharges from the C-100, C-100A, C-100B, and $\mathrm{C}-100 \mathrm{C}$ canals. The $40.6-\mathrm{mi}^{2}$ drainage area controlled by these canals was drained after 1967 and is generally not prone to flooding. Saltwater intrusion protection by structure S-123 is important.
Structure S-21 (fig. 1) controls flows to tidewater from the C-1 canal. This canal was constructed in 1961 to prevent flooding, which previously occurred in its 56.9- $\mathrm{mi}^{2}$ drainage basin (Merritt, 1995).

Structures S-21A, S-20G, S-20F, and S-20 (fig. 1) serve as barriers to saltwater intrusion. The $C-102$ and C-103 canals are east-west outlets channels once used to drain the low-lying coastal glades. Structure S-21 A regulates the flow to tidewater from the C-102 canal, and structure S-20F regulates the flow from the C-103 canal. The headwater of both coastal structures is connected through the north-south L-31E canal. Structure S-20G, located south of structure S-21A and north of structure $S-20 F$, regulates the flow to tidewater from Military Canal, which was constructed in 1945 to drain areas surrounding the Homestead Army Air Field, now called Homestead Air Force Base (fig. 1). Farther south, the L-31E canal discharge is released to tidewater through structure S-20 on the C-107 canal.

Structure S-197 (fig. 1) is located at the southern end of the C-111 canal, which drains an area of about $100 \mathrm{mi}^{2}$. This coastal structure originally consisted of earthen plugs that were removed in times of flood, and presently S-197 has 13 gated culverts that are opened intermittently for drainage of excess water to Barnes Sound.

\section{Acknowledgments}

The authors would like to thank the stream gaging teams from the USGS and SFWMD for their assistance in the flow measurements. We would also like to thank Drue Pautz, an SFWMD intern, who assisted in the data analysis and hydrograph plotting; Victor Powell, Deputy Director of the SFWMD Operations Management Division and the Miami and Homestead field stations, for authorization and operation of the coastal structures; and Matthew Swain of Analytical Technologies Inc., for the aerial flyovers used for the photography.

\section{METHODS OF INVESTIGATION}

The subsequent sections of this report describe the methods and procedures that were used in the development of discharge-coefficient ratings for the 16 coastal structures in Dade County. The first two sections describe the techniques that were applied in rating gated spillways and gated culverts, the third section 
discusses the procedure in measuring discharge with acoustic Doppler methods, and the final section describes the field protocol used in the study.

\section{Rating Gated Spillways}

During 1960-61, the COE performed a study on a 1:16 scale physical model of a typical SFWMD (known then as the Central and Southern Florida Flood Control District) gated coastal structure (U.S. Army Corps of Engineers, 1963). The test results indicated that four possible flow regimes exist: submerged orifice flow, submerged weir flow, free orifice flow, and free weir flow (fig. 2). The COE developed theoretical flow equations for the stage-discharge relations for the gated spillway coastal structures under these regimes. In their laboratory analyses, the $\mathrm{COE}$ also determined experimental values for the discharge coefficients under these flow regimes, relating the coefficients and pertinent variables in plots (U.S. Army Corps of Engineers, 1963). Since then, the SFWMD has applied the COE equations and calibrated them for each individual coastal structure (Otero, 1994).
Orifice-flow equations are used where flows are controlled by gates, and weir-flow equations are used where flows are not controlled by gates. Whether the flow is free or submerged depends on the downstream stage. Free flow occurs when the downstream stage is low enough relative to the sill that it does not affect flows. Flows are computed using only upstream watersurface elevations and physical characteristics of the orifice or weir. Submerged orifice and submerged weir flows are common in the coastal structures. Free flow is rare because the sill elevations are low with respect to sea level at these coastal structures. An exact gate opening is difficult to define where the gate no longer affects flow. Collins (1977) considered submerged weir flow to exist if the gate opening were greater than twothirds the height of the upstream water level over the gate sill. Otero (1994) considered a transition zone from gate openings three-fifths the upstream water level over the gate sill to a point where the gates were out of the water. This transition zone, which is neither orifice nor weir flow, was assumed to occur when the flow coefficient no longer changed with the gate opening. Weir flow is considered to be in the flow regime where the flow is unaffected by the gate. Submerged

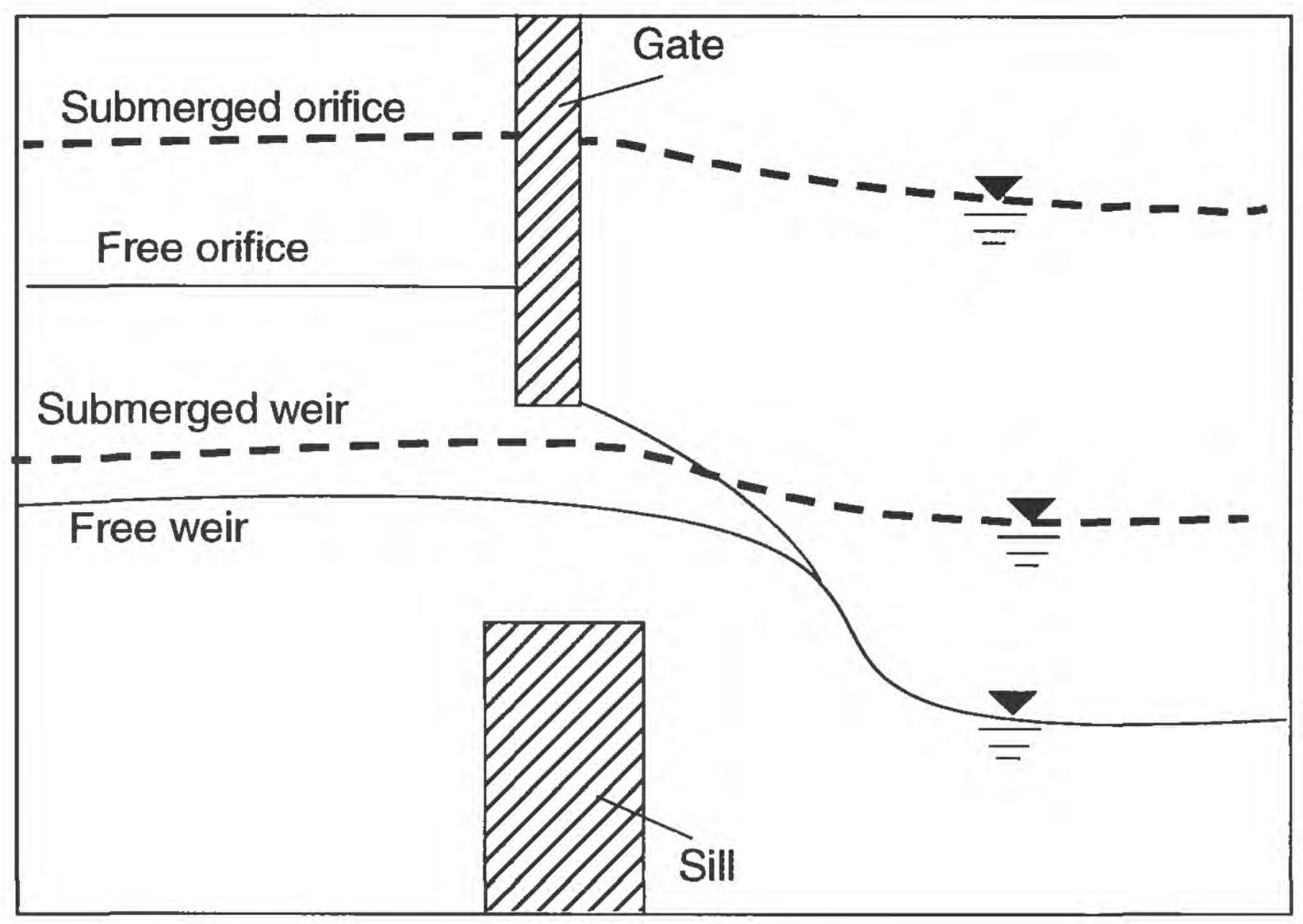

Figure 2. Flow regimes for a gated spillway. 
orifice flow is expressed by the equation (U.S. Army Corps of Engineers, 1963; Collins, 1977):

$$
Q=C_{g s} L h \sqrt{2 g(H-h)},
$$

where $Q$ is discharge in cubic feet per second, $C_{g S}$ is the discharge coefficient relative to the function of a gate opening and submergence, $L$ is length of gate sill, $g$ is gravitational acceleration, $H$ is headwater height above sill, and $h$ is tailwater height above sill. $C_{g s}$ can be derived from field measurements by rearranging equation 1 as:

$$
C_{g s}=\frac{Q}{L h \sqrt{2 g(H-h)}} .
$$

Because $C_{g s}$ is considered to be both the function of a gate opening and submergence, values of $C_{g s}$ computed from field measurements are plotted against the dimensionless parameter $h / G$ in a log-log plot, where $G$ is the gate opening. As the downstream becomes less submerged, flows increase, downstream stage $h$ is less, and the value of $h / G$ decreases. As the gate is opened more, flows increase, $G$ is greater, and the value of $h / G$ decreases. Thus, $h / G$ should be strongly related to $Q$. A least squares best fit to available data points yields the rating curve, which is a "sample" estimate of the true relation. The sensitivity of the fit is inversely proportional to data points available.

Submerged weir flow can be expressed by (U.S. Army Corps of Engineers, 1963):

$$
Q=C_{w s} \sqrt{2 g} L h \sqrt{H-h},
$$

where $C_{w s}$ is a constant discharge coefficient for weir flow. $C_{g s}$ should approach $C_{w s}$ as the gate opening approaches weir flow.

The standard USGS method for describing submerged weir flow is described in Collins (1977):

$$
Q=C_{s} C_{w} L H^{1.5}
$$

where $C_{s}$ is a submergence coefficient relative to the function of $h / H$, and $C_{w}$ is the discharge coefficient for free weir flow. Equations 3 and 4 were applied to the field data that were collected. Although equations 3 and 4 adequately fit the range of field data, an attempt to extrapolate equation 4 to lower $h / H$ values yielded unacceptable results. Thus, it was decided that equation 3 would be used to express submerged weir flow.

\section{Rating Gated Culverts}

Structures G-58, S-25, and S-197 consist of a single gated culvert or multiple gated culverts. Ratings for gated culverts include multiple flow conditions depending on submergence of the upstream and downstream ends. These three coastal structures were submerged throughout for the conditions measured in this study. The standard rating equation for a submerged culvert used in southern Florida originates from the orifice-flow equation:

$$
H-h=K \frac{v^{2}}{2 g},
$$

where $K$ is a flow coefficient which accounts for the entrance, friction, and exit losses; $v=Q / A$, the mean flow velocity; and $A$ is the open area of the gate. With some manipulation, equation 5 becomes:

$$
Q=A C_{c} \sqrt{2 g(H-h)},
$$

where $C_{c}$ is a submerged culvert coefficient. For a circular culvert, this area $A$ is determined by:

$$
\begin{gathered}
A=\frac{D}{4}\left(D \operatorname{acos}\left(\frac{D-2 G}{D}\right)\right. \\
\left.-(D-2 G) \sin \left[\operatorname{acos}\left(\frac{D-2 G}{D}\right)\right]\right)
\end{gathered}
$$

where $D$ is the diameter of the culvert.

In the case of the gated spillways, the field determined $C_{g s}$ values are plotted against $h / G$ due to their dependence on submergence and the gate opening. Flow through a submerged culvert also depends on submergence and the gate opening; however, the flow area is not a linear function of the gate opening for a circular culvert as is the case with a rectangular spillway. Instead of using gate opening $G$, the hydraulic radius of the gate opening $R=A / P$ (to plot against $C_{c}$ ) is used, where $P$ is the wetted perimeter of the gate opening (fig. 3). Thus, $P$ is calculated by: 


$$
P=D\left(\operatorname{acos}\left(\frac{D-2 G}{D}\right)+\sin \left[\operatorname{acos}\left(\frac{D-2 G}{D}\right)\right]\right) .
$$

Values of $C_{C}$ determined from field measurements are plotted against $(H-h) / R$ on a linear scale plot. These calculated data are used for the least squares best fit.

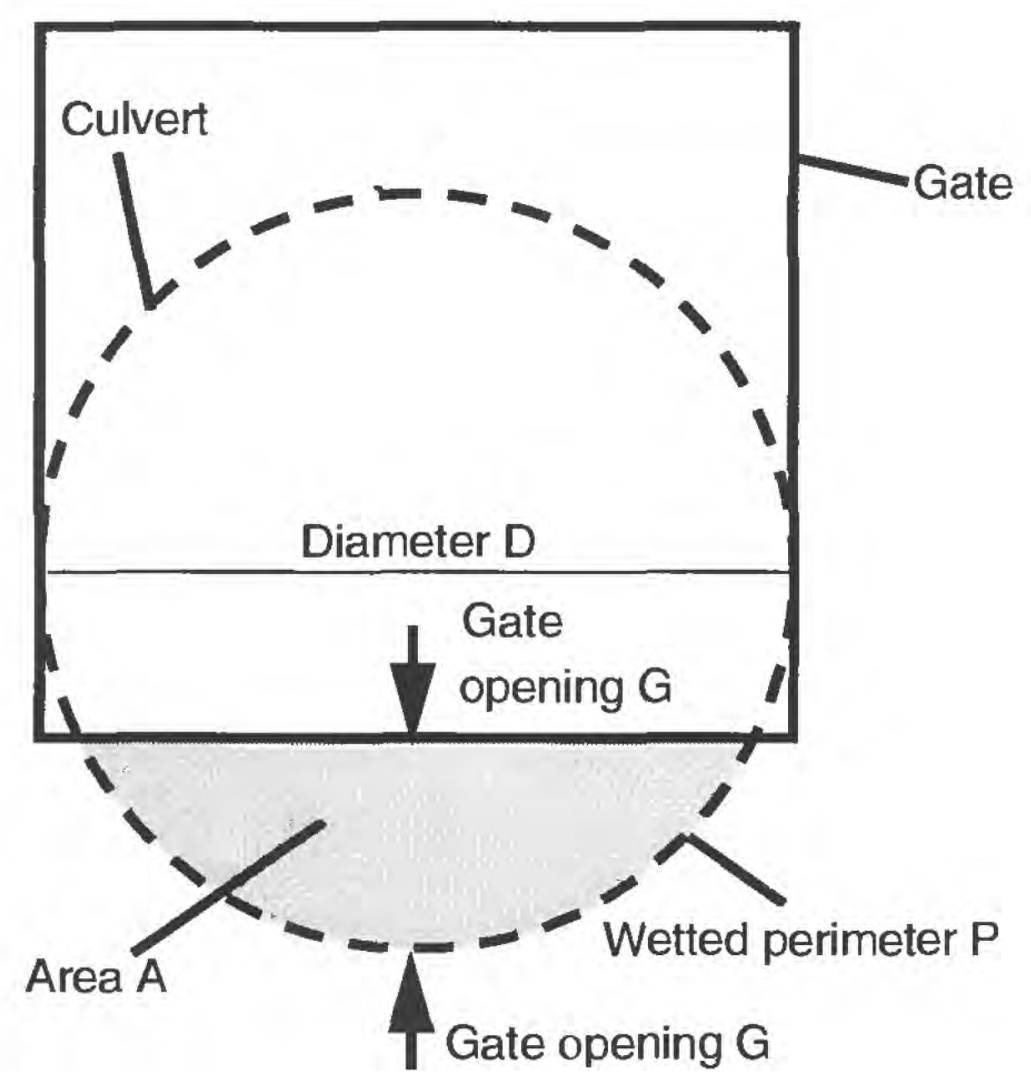

Figure 3. A typical gated culvert.

Actual field measurements used to determine values for the discharge coefficients, as opposed to existing theoretical flow coefficient values, should produce more accurate ratings. Theoretical-coefficient ratings do not take into account variations and peculiarities in the system and loss of energy due to turbulence and contractions in the flow regime of the field structure, such as debris, algae growth, and hydrilla.

\section{Acoustic Doppler Techniques}

Existing theoretical-coefficient ratings are based on flows through idealized structures (the 1:16 scale physical COE model) of the same proportions as the field structures. These do not take into account variations and peculiarities in the flow regime of the field structures. To properly estimate $C_{g s}$ and $C_{w s}$ in equations 2 and 3 , respectively, field measurements of flows must be taken at the same time as that water elevations and structure operations are recorded. The use of an
Acoustic Doppler Current Profiler (ADCP) is ideal for taking these measurements.

Several factors make measuring discharge near coastal structures difficult. Very low velocities, less than $0.2 \mathrm{ft} / \mathrm{s}$ (foot per second), can occur especially when the canal is significantly wider than the flow-way of the coastal structure. Additionally, the spatial distribution of velocities can be quite varied near a coastal structure because the flow through the structure disrupts the normal flow pattern in the canal. The ADCP is capable of taking measurements under these conditions.

The ADCP uses the Doppler shift in reflected acoustic signals to determine the velocity of moving water (RD Instruments, 1989). A schematic of the acoustic transducers and the transmitted and reflected signals is shown in figure 4. The ADCP can locate the vertical position where the measured velocities occurred by the traveltimes of the transmitted and received signals (Simpson and Oltmann, 1991) and integrate them to find an average velocity. Additionally, the Doppler shift in the signal reflected from the canal bottom determines the water velocity. The measurement can be taken from a moving boat with the ADCP automatically subtracting the boat velocity from the measured velocity. Total discharge and direction of flow are computed by the ADCP software. A discharge measurement can be taken rapidly at low, irregular flow conditions. For these reasons, the ADCP was used for measuring flow at the coastal structures in Dade County.

An ADCP measurement can be taken in minutes, which represent a considerable reduction in the time required using the Price current meter (a mechanical point velocity meter). This allowed for the more accurate collection of data in the dynamic conditions that were encountered in this study (for example, a discharge measurement could be taken before water levels changed substantially). Another advantage of the ADCP over the Price current meter is that data are collected on a continuum in the water column and cross section rather than at discrete points (Lipscomb, 1995).

A disadvantage of the older ADCP system is that it required a minimum profiling depth of about $11.5 \mathrm{ft}$ (feet). The newer ADCP system can measure flow at a minimum depth of $3.4 \mathrm{ft}$ (Simpson and Oltmann, 1991). However, velocity-profile data cannot be collected very close to the banks of a channel. The ADCP software uses an algorithm for estimating discharges in the shallow regions that cannot be measured (Simpson 


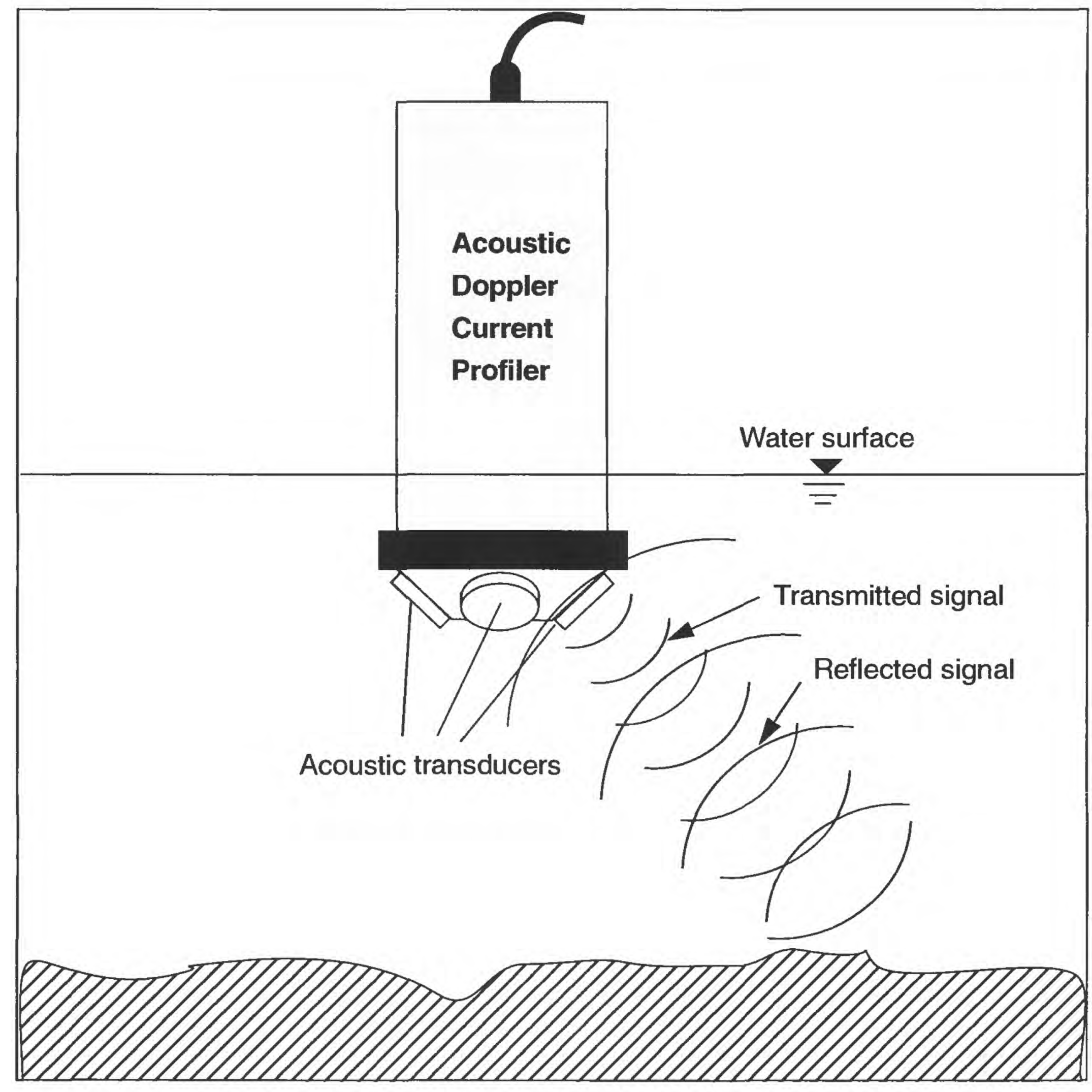

Figure 4. Schematic of signal path of an Acoustic Doppler Current Profiler. 
and Oltmann, 1991). Velocity errors with the new ADCP system have been reduced to $0.075 \mathrm{ft} / \mathrm{s}$.

\section{Field Protocol}

ADCP measurements by the USGS were taken simultaneously with those taken using ADCP equipment (from the SFWMD) at the coastal structure sites. Access to all sites was made upstream, using a small jon-boat in almost every case. A typical monitoring setup is shown at structure S-20 on the C-107 canal in figure 5. Two boats with ADCP's are being used at this site; one is directly upstream of the coastal structure and the other is around the bend to the left (fig. 5). Both boats have ADCP's mounted on their bows and are pointed into the flow. Taglines are stretched across the canals for each boat, and the boats are pulled by hand slowly across for the measurement. The blockhouse to the coastal structure contains the upstream and downstream stage recorders. Stages and gate openings were noted at the beginning and end of every measurement. The gate is controlled from the blockhouse. Although most structures are controlled by telemetry, manual control can be made from the blockhouse.

The difference in headwater and tailwater was determined by standard metal-float stage recorders installed upstream and downstream at each coastal

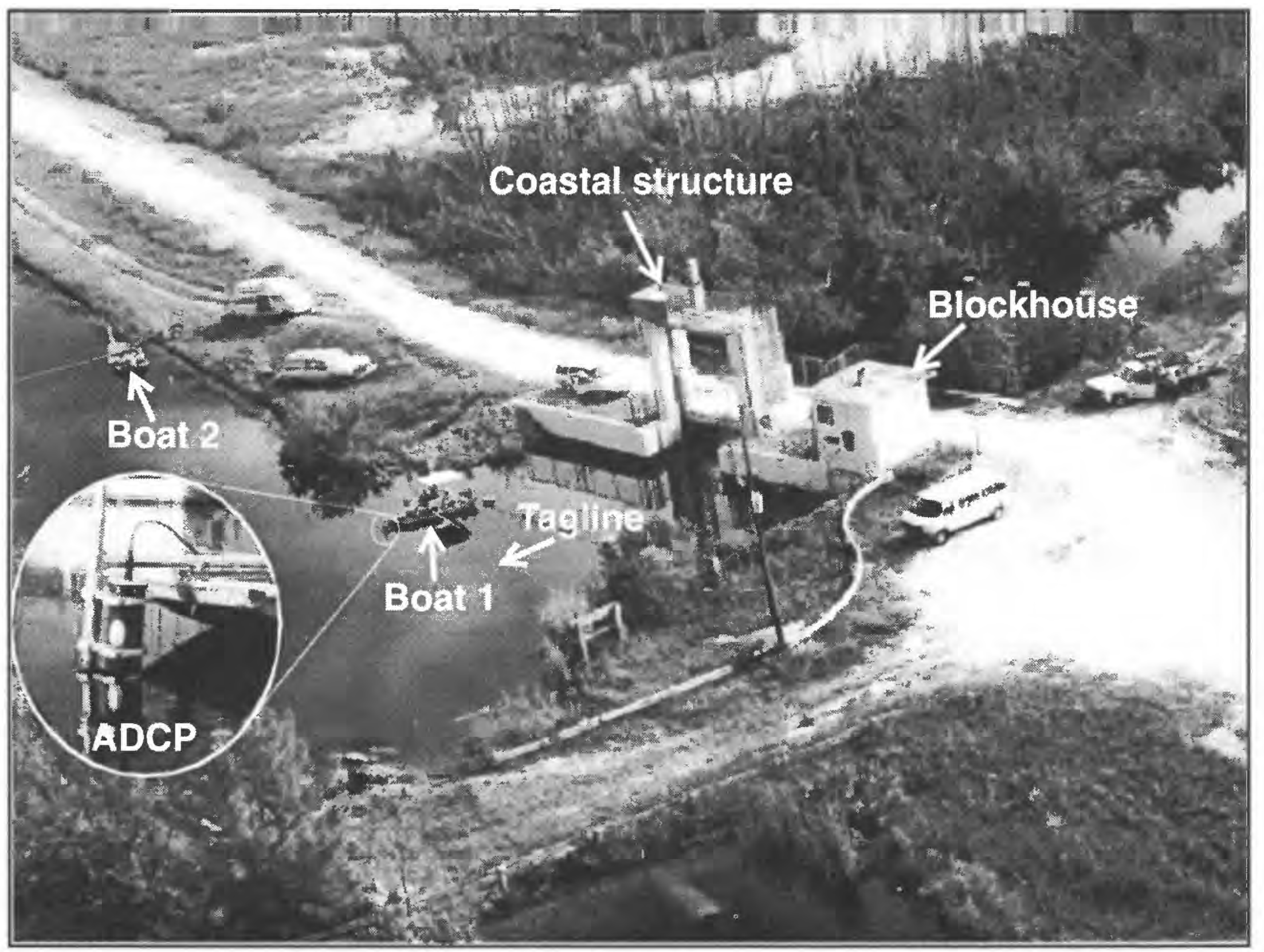

Figure 5. Typical field setup for an Acoustic Doppler Current Profiler (ADCP) measurement of streamflow. 
structure site over stilling wells. These recorders were leveled to sea level, but the most accurate leveling must be between the two recorders. Manometric methods were used to confirm this leveling of the recorders and measure small head differences.

Measurements were taken under a variety of flow conditions at each coastal structure. In coordination with the SFWMD, measurements were scheduled (table 2) depending on system conditions, which determined allowable gate operations. When sufficient water was available for release, the SFWMD implemented various gate openings over a relatively short period to provide a variety of flow conditions for the measurements.

Flow at structure $\mathrm{S}-25$, a gated culvert, was measured by a point-velocity measurement device, called a Smart Acoustic Current Meter (SACM), instead of the
ADCP. The SACM uses an acoustic traveltime over a path of several inches to make a point determination of water velocity. The SACM was found to be more successful for measuring flow at structure S-25 than the ADCP, which could not measure in the dense vegetation.

\section{DISCHARGE-COEFFICIENT RATINGS FOR THE DADE COUNTY COASTAL STRUCTURES}

All of the 16 coastal structures in eastern Dade County presented in this report regulate the total surfacewater flows to Biscayne Bay and associated water bodies (fig. 1). The next sections of this report describe the techniques that were used to determine discharge-coefficient

Table 2. Dates of measurement

[ADCP, Acoustic Doppler Current Profiler]

\begin{tabular}{|c|c|c|c|c|c|}
\hline Structure & $\begin{array}{c}\text { Dates of } \\
\text { measurement }\end{array}$ & $\begin{array}{c}\text { No. of } \\
\text { ADCP's } \\
\text { employed }\end{array}$ & Structure & $\begin{array}{c}\text { Dates of } \\
\text { measurement }\end{array}$ & $\begin{array}{l}\text { No. of } \\
\text { ADCP's } \\
\text { empoyed }\end{array}$ \\
\hline G-58 & $06-20-95$ & 2 & $\mathrm{~S}-25^{1}$ & $\begin{array}{l}03-28-95 \\
09-21-95\end{array}$ & $\begin{array}{l}2 \\
1\end{array}$ \\
\hline G-93 & $\begin{array}{l}03-24-95 \\
03-27-95 \\
06-22-95\end{array}$ & $\begin{array}{l}1 \\
1 \\
1\end{array}$ & $\mathrm{~S}-25 \mathrm{~B}$ & $\begin{array}{l}11-20-95 \\
12-11-94 \\
03-29-95\end{array}$ & $\begin{array}{l}1 \\
1 \\
1\end{array}$ \\
\hline S-20 & $\begin{array}{l}03-20-95 \\
06-21-95 \\
09-19-95\end{array}$ & $\begin{array}{l}1 \\
2 \\
2 \\
\end{array}$ & S-26 & $03-28-95$ & 1 \\
\hline $\mathrm{S}-20 \mathrm{~F}$ & $06-19-95$ & 2 & S-27 & $\begin{array}{l}11-19-94 \\
03-29-95 \\
06-22-95\end{array}$ & $\begin{array}{l}1 \\
1 \\
1\end{array}$ \\
\hline S-20G & $\begin{array}{l}03-21-95 \\
03-22-95 \\
09-18-95\end{array}$ & $\begin{array}{l}1 \\
1 \\
2\end{array}$ & S-28 & $\begin{array}{l}11-19-94 \\
03-31-95\end{array}$ & $\begin{array}{l}1 \\
1\end{array}$ \\
\hline S-21 & See footnote 2 & 0 & S-29 & $\begin{array}{l}11-19-94 \\
03-31-95 \\
09-21-95\end{array}$ & $\begin{array}{l}1 \\
1 \\
1 \\
\end{array}$ \\
\hline S-21A & $03-23-95$ & 1 & S-123 & $\begin{array}{l}03-21-95 \\
09-20-95\end{array}$ & $\begin{array}{l}1 \\
1\end{array}$ \\
\hline S-22 & $03-30-95$ & 1 & S-197 & $\begin{array}{l}11-18-94 \\
06-23-95 \\
10-19-95 \\
10-24-95\end{array}$ & $\begin{array}{l}1 \\
1 \\
1 \\
1\end{array}$ \\
\hline
\end{tabular}

\footnotetext{
'One of the meters used at structure S-25 on 03-28-95 was a Smart Acoustic Current Meter.

${ }^{2}$ No measurements were taken at structure S-21 because a substantial historical set of measurements exists for this coastal structure.
} 
ratings for the Dade County coastal structures. Flood discharge characteristics for each coastal structure are presented in appendix I, and structural data for each coastal structure are presented in appendix II. Also discussed in appendix I (and on the accompanying pages) is the design flood percentage. This is a specific percentage that reflects a degree of protection varying from structure to structure of the Standard Project Flood (SPF) runoff. The SPF runoff is a structure specific value describing the amount of rainfall runoff associated with the 100-year storm (U.S. Army Corps of Engineers, 1995). A glossary of the mathematical symbols used in the logarithmic and linear scale plots (presented in the next sections) is given in appendix III.

\section{Structure S-29}

Structure S-29 (fig. 6) is a reinforced-concrete gated spillway with discharge controlled by four cable-operated, vertical lift gates. This coastal structure is located in North Miami Beach near the mouth of the C-9 canal (Snake Creek Canal) and is about $500 \mathrm{ft}$ from Lake Maule (fig. 1). Structure S-29 maintains optimum water-control stages upstream in the C-9 canal and prevents saltwater intrusion during periods of high tide. Additionally, structure S-29 passes the design flood (100 percent of the SPF) without exceeding upstream flood design stage criteria set by water managers and restricting downstream flood stages and discharge velocities to nondamaging levels. Appendix I presents flood discharge characteristics for structure S-29, and appendix II presents structural data for $\mathrm{S}-29$.

ADCP measurements were taken at structure S-29 on November 19, 1994, March 31, 1995, and September 21, 1995 (table 2). Initial measurements (November 1994) were taken at the measurement section shown in figure 6 , with all four gates open at $10 \mathrm{ft}$. The initial measurements were not comparable to later ones taken at another measurement section (not shown) closer to the coastal structure. For the March 1995 measurements, not as much water was available (as was available for the initial measurements), and gate openings from 1 to $6 \mathrm{ft}$ were obtained at only one gate. The March 1995 measurements yielded a good set of data for submerged orifice flow, but not for submerged weir flow. The September 1995 measurements were taken at the measurement section (fig. 6) with one gate open at $11.5 \mathrm{ft}$. Although the gate was not high enough to be out of the water (the gate was as high as possible), it was submerged weir flow. Logarithmic and linear scale plots of the discharge-coefficient ratings for the submerged orifice- and submerged weir-flow regimes are shown in figure 7.

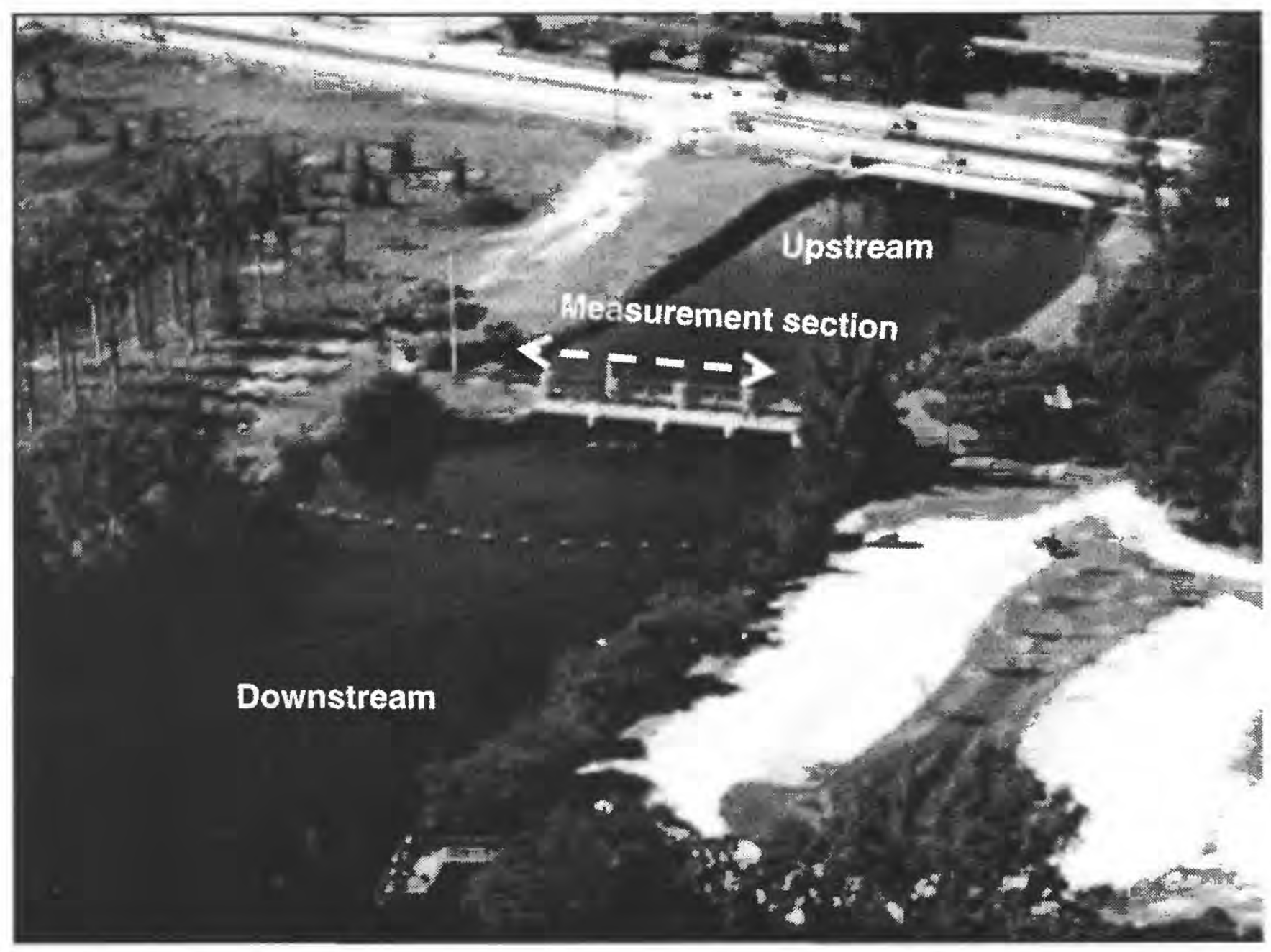

Figure 6. Structure S-29. 

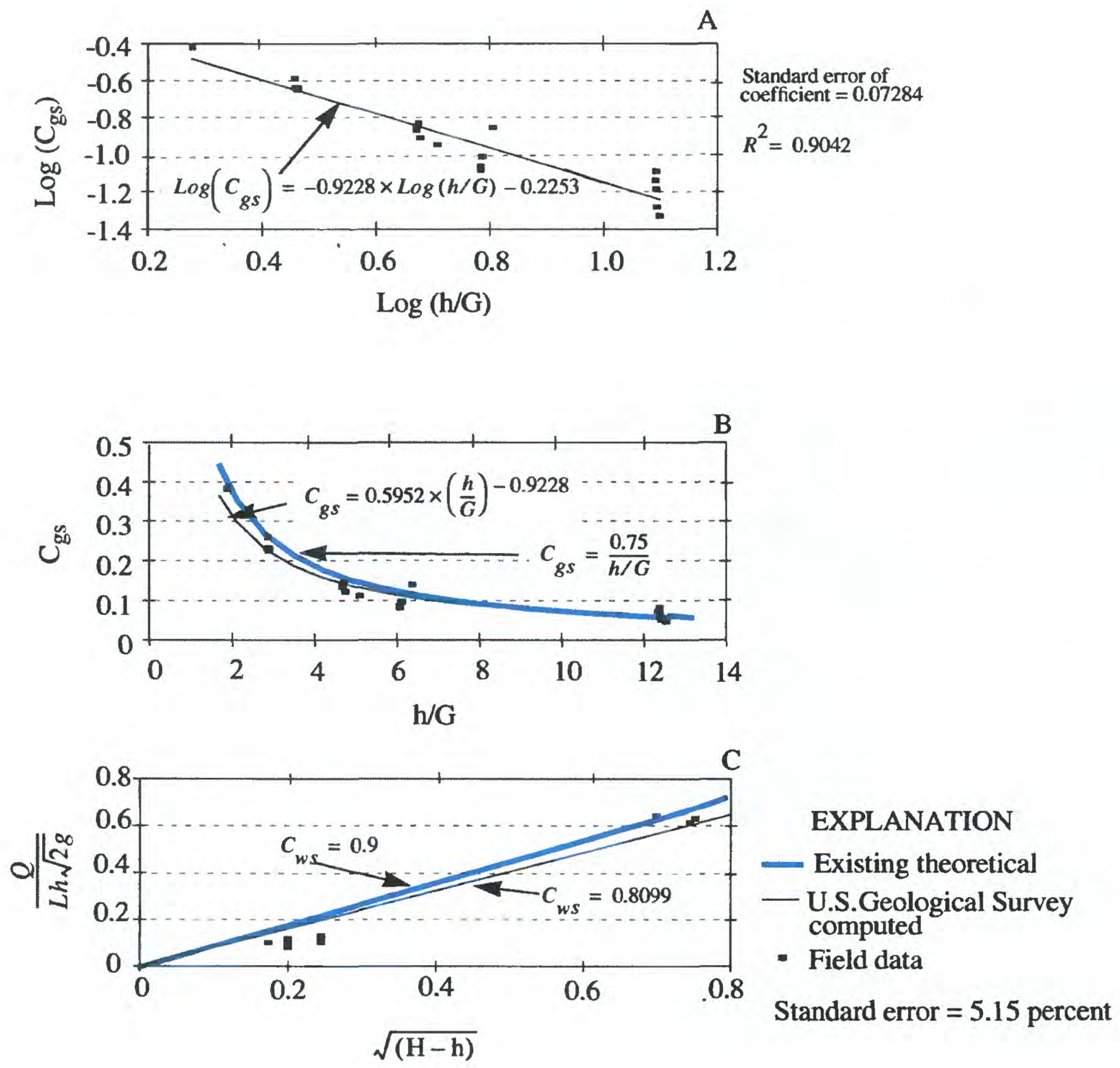

Figure 7. Logarithmic plot of the S-29 discharge coefficient for submerged orifice flow (graph A) and linear scale plots of a comparison of the S-29 discharge coefficient for submerged orifice flow (graph B) and submerged weir flow (graph C). An explanation of the mathematical symbols is given in appendix III. 
The flow through structure S-29 was computed for 1994 using both the theoretical- and computedcoefficient ratings as shown in figure 8 . The ratings are very similar with some significant deviations at the highest flows. The total flow for 1994 using the theoretical-coefficient rating is 262,843 acre-ft (acrefeet), and the total flow using the computed-coefficient rating is 237,892 acre-ft. The volumes differ by about 10.5 percent. Some negative flows were allowed at structure S-29.

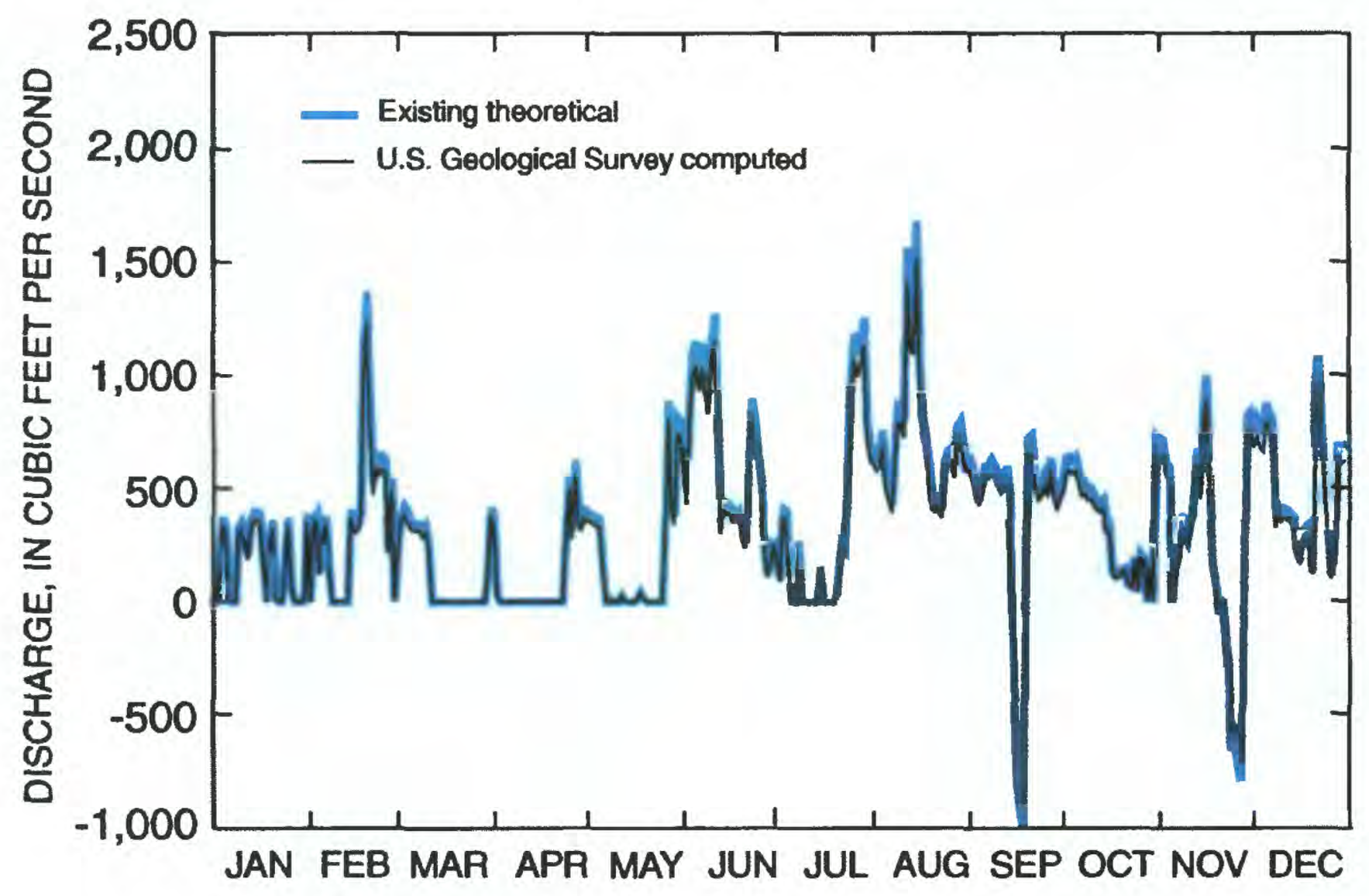

Figure 8. Theoretical and computed flows for structure S-29 in 1994. 


\section{Structure G-58}

Structure G-58 (fig. 9) is a four-barrel, corrugated-metal-pipe culvert located on Arch Creek (fig. 1), immediately downstream from the Florida East Coast Railroad bridge in the bridge abutment of N.E. 135th Street in Miami. This nontelemetric coastal structure maintains optimum water-control stages upstream in Arch Creek and prevents saltwater intrusion during periods of high tide. Additionally, structure G-58 passes the design flood (60 percent of the SPF) without exceeding upstream flood design stage criteria set by water managers and restricting downstream flood stages and discharge velocities to nondamaging levels. Appendix I presents flood discharge characteristics for structure G-58, and appendix II presents structural data for G-58.

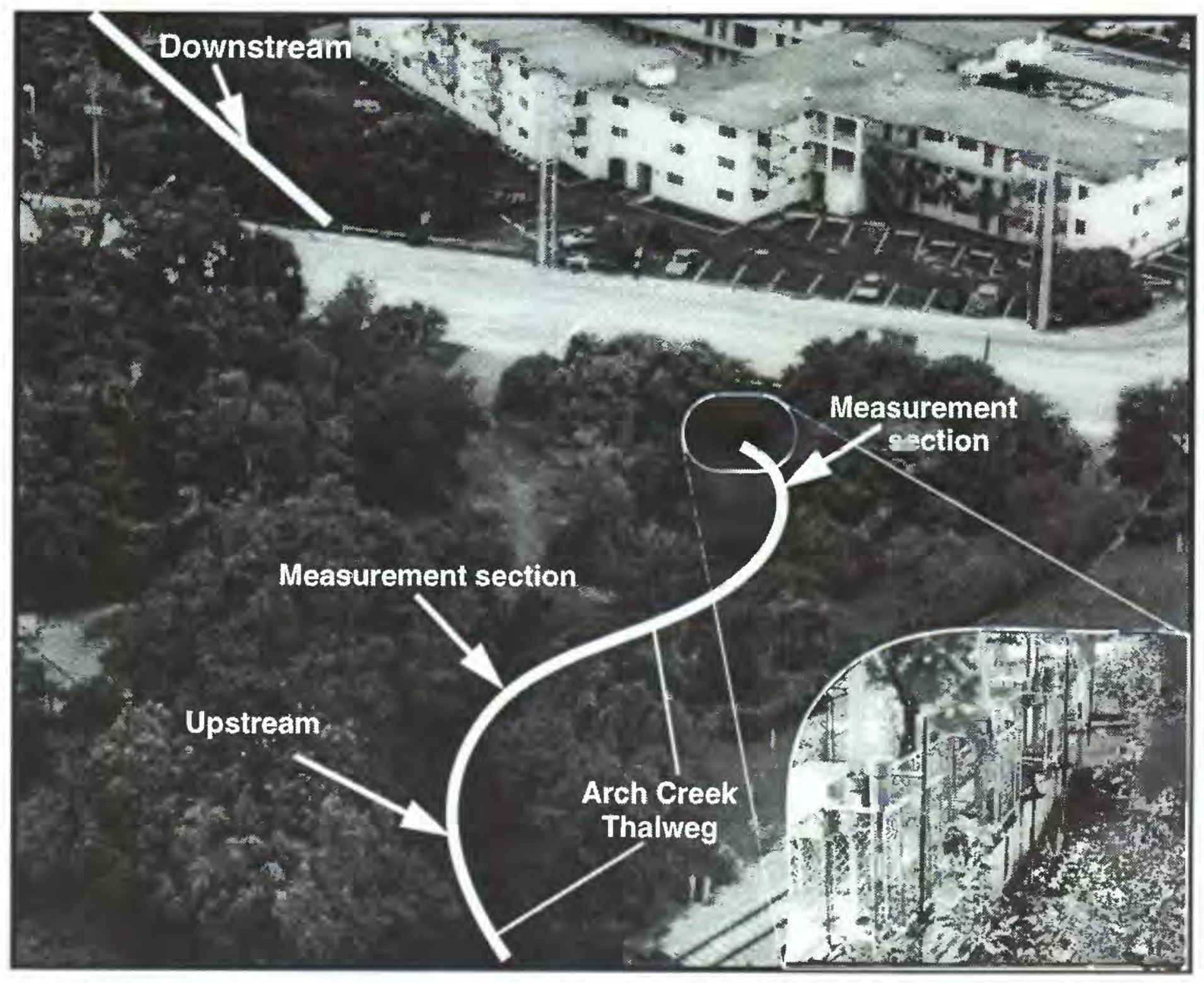

Figure 9. Structure G-58. 
Two ADCP's were used to take measurements at structure G-58 on June 20, 1995 (table 2). One measurement section was immediately upstream of the coastal structure and the other was farther upstream as shown in figure 9. Measurements at the section farthest upstream could not be used because of problems with the data files. However, sufficient data were collected at the section immediately upstream to develop a discharge-coefficient rating for submerged orifice flow shown as a linear scale plot in figure 10 . The following gate openings were used to obtain a discharge rating: One 72-in. (inch) diameter culvert open at 1 and $2 \mathrm{ft}$, one 60-in. diameter culvert open at $1 \mathrm{ft}$, and two 72-in. diameter culverts simultaneously open at $1 \mathrm{ft}$.

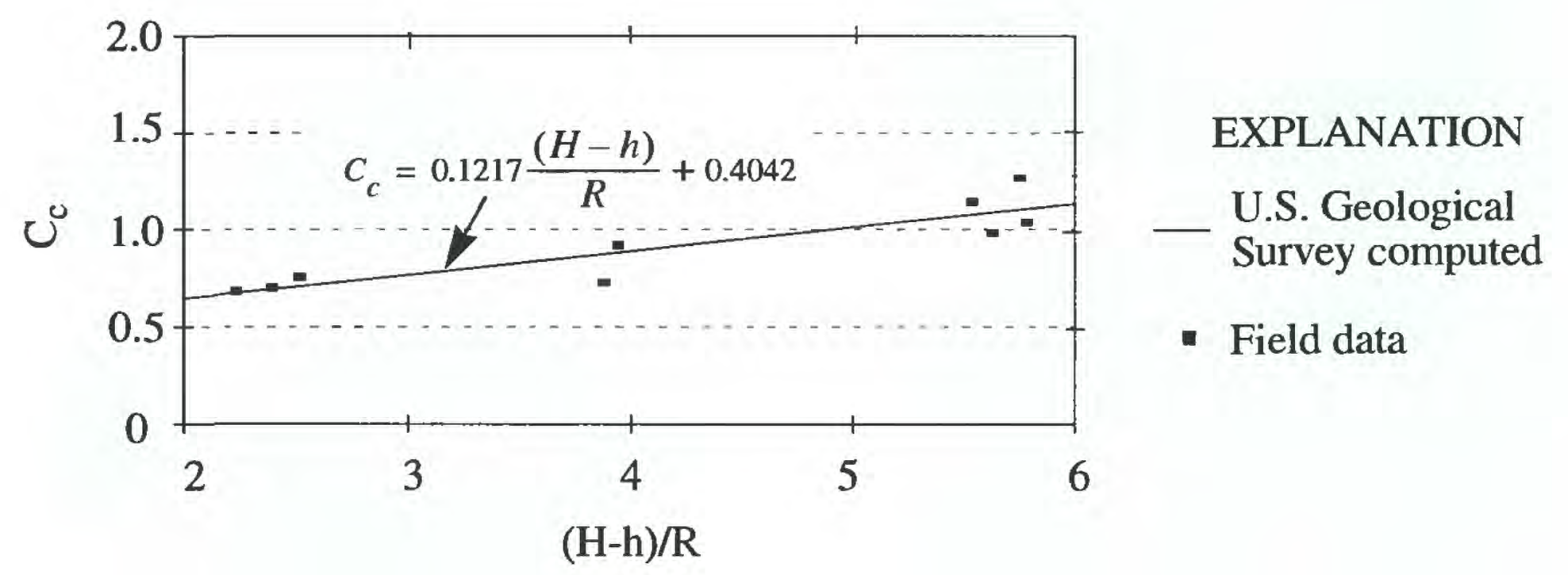

Figure 10. Linear scale plot of the discharge coefficient for the G-58 gated culvert. An explanation of the mathematical symbols is given in appendix III. 


\section{Structure S-28}

Structure S-28 (fig. 11) is a reinforced-concrete gated spillway with discharge controlled by two cableoperated, vertical lift gates. This coastal structure is located in Miami near the mouth of the C- 8 canal (Biscayne Canal) and is about $1 \mathrm{mi}$ from Biscayne Bay (fig. 1). Structure S-28 maintains optimum water-control stages upstream in the $\mathrm{C}-8$ canal and prevents saltwater intrusion during periods of high tide. Additionally, structure S-28 passes the design flood (100 percent of the SPF) without exceeding upstream flood design stage criteria set by water managers and restricting downstream flood stages and discharge velocities to nondamaging levels. The automatic controls on this coastal structure have an overriding mechanism that closes the gates, regardless of the upstream water level in the event of high tide, when the differential between the falling headwater and rising tailwater pool elevations reaches $0.3 \mathrm{ft}$. During the simultaneous occurrence of high tide and heavy rainfall in the low-lying urban areas draining into the $\mathrm{C}-8 \mathrm{canal}$, the structure control is placed on manual control and the gates open when the headwater exceeds that of the tailwater. A timing device that prevents sudden gate closing has been installed to protect manatees during automatic gate operation. Appendix I presents flood discharge characteristics for structure S-28, and appendix II presents structural data for S-28.

ADCP measurements were taken at structure S-28 on November 19, 1994, and March 31, 1995 (table 2). Submerged weir flow existed during the November 1994 measurements, and submerged orifice flow existed during the March 1995 measurements. Initial measurements (November 1994) were taken at the measurement section farthest from the coastal structure (fig. 11) with two gates open at $10 \mathrm{ft}$. The latter measurements (March 1995) were taken at the measurement section closest to the coastal structure with one gate open at $3,4,5,6$, and $8 \mathrm{ft}$ and two gates simultaneously open at 3 and $4 \mathrm{ft}$ for each. Logarithmic and linear scale plots of the discharge-coefficient ratings for the submerged orifice- and submerged weir-flow regimes are shown in figure 12 .

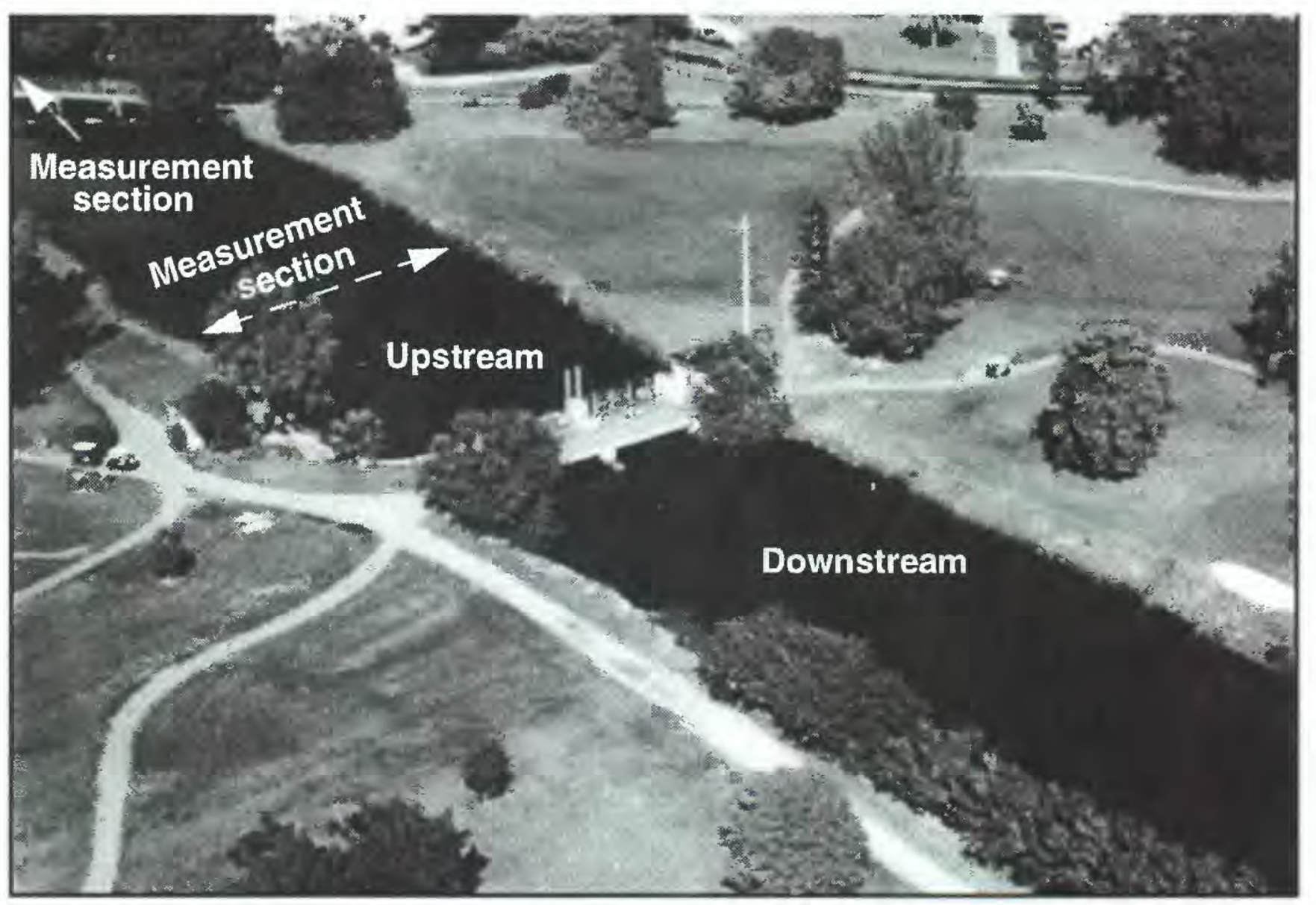

Figure 11. Structure S-28. 

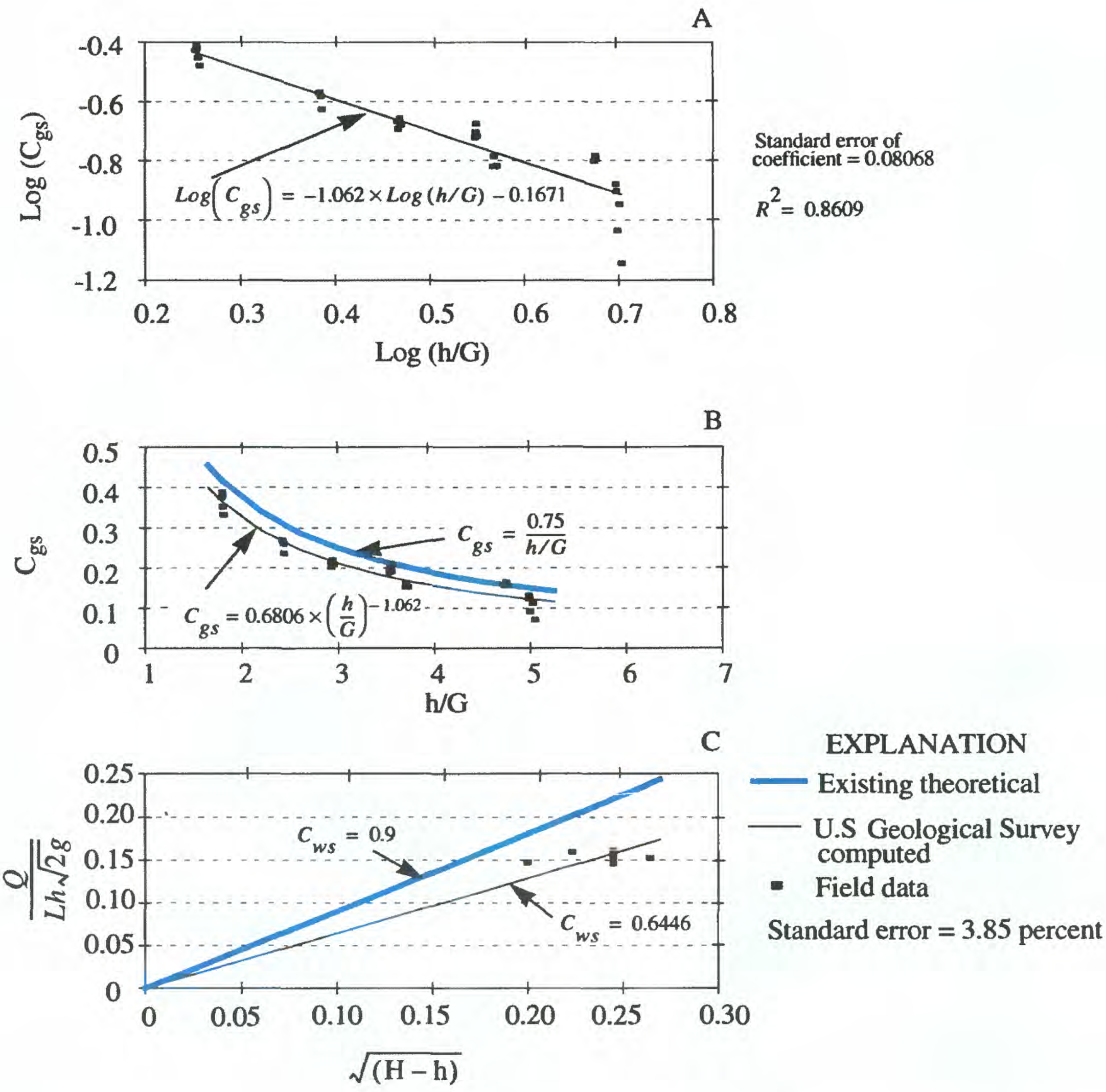

Figure 12. Logarithmic plot of the S-28 discharge coefficierit for submerged orifice flow (graph A) and liriear scale plots of a comparison of the S-28 discharge coefficient for submerged orifice flow (graph B) and submerged weir flow (graph C). An explanation of the mathematical symbols is given in appendix III. 
The flow through structure S-28 was computed for 1994 using both the theoretical- and computedcoefficient ratings as shown in figure 13 . The ratings are very similar, indicating that the existing theoretical-coefficient rating was determining values quite well for this coastal structure. If there were significant weir flow, the hydrograph comparison would not have been so close. The total flow for 1994 using the theoretical-coefficient rating is 115,883 acre- $\mathrm{ft}$, and the total flow using the computed-coefficient rating is 108,013 acre-ft. The volumes differ by about 7.3 percent.

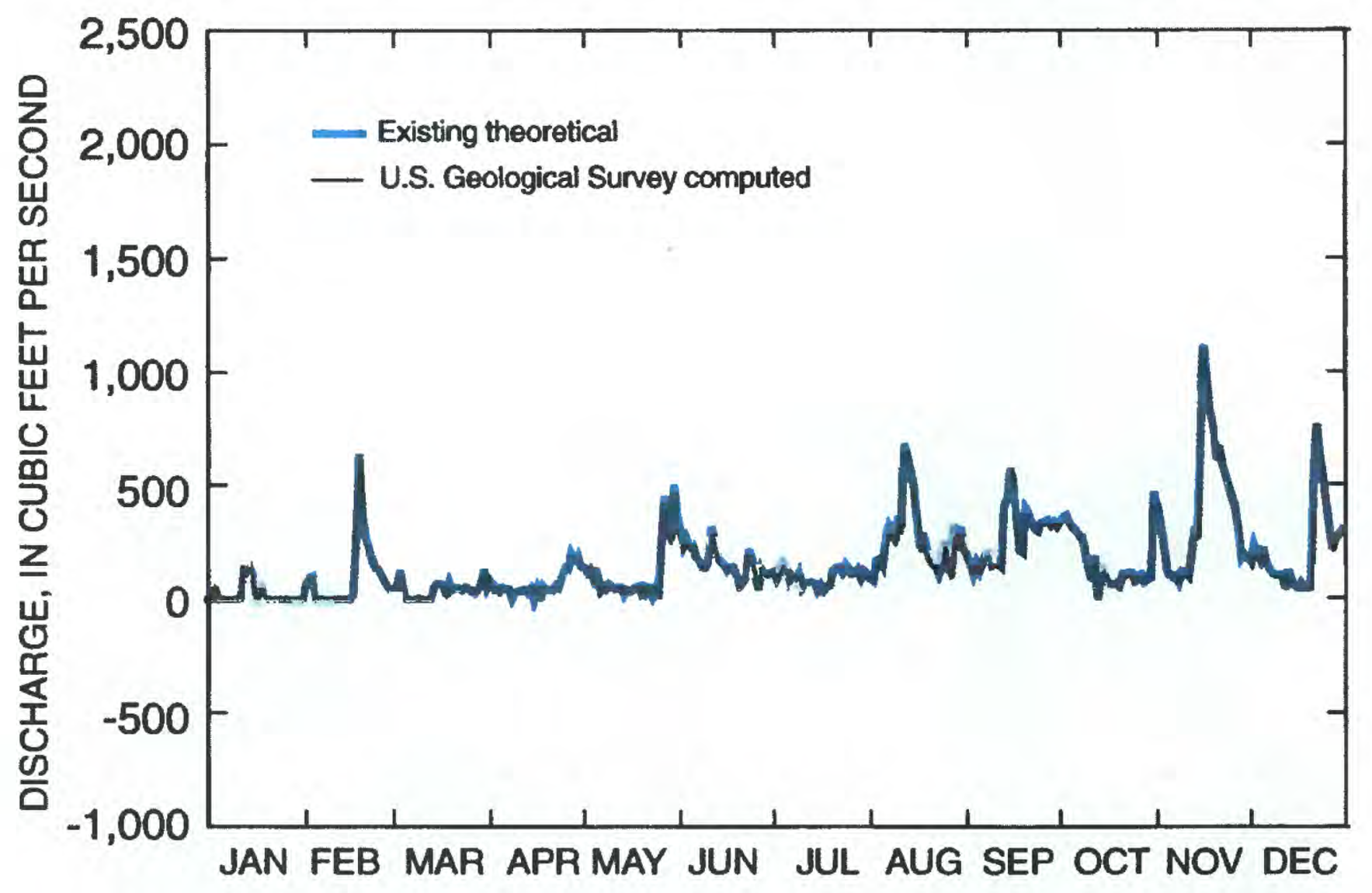

Figure 13. Theoretical and computed flows for structure S-28 in 1994. 


\section{Structure S-27}

Structure S-27 (fig. 14) is a reinforced-conçrete gated spillway with discharge controlled by two cableoperated, vertical lift gates. This coastal structure is located in Miami near the mouth of the C-7 canal (Little River Canal) and is about $1.3 \mathrm{mi}$ from Biscayne Bay (fig. 1). Structure S-27 maintains optimum watercontrol stages upstream in the C-7 canal and prevents saltwater intrusion during periods of high tide. Additionally, structure S-27 passes the design flood (75 percent of the SPF) without exceeding upstream flood design stage criteria set by water managers and restricting downstream flood stages and discharge velocities to nondamaging levels. The automatic controls on this coastal structure have an overriding mechanism that closes the gates, regardless of the upstream water level in the event of high tide, when the differential between the falling headwater and rising tailwater pool elevations reaches $0.2 \mathrm{ft}$. During the simultaneous occurrence of high tide and heavy rainfall in the low-lying urban areas draining into the $\mathrm{C}-7$ canal, the structure control is placed on manual control and the gates open when the headwater exceeds that of the tailwater. A timing device that prevents sudden gate closing has been installed to protect manatees during automatic gate operation. Appendix I presents flood discharge characteristics for structure S-27, and appendix II presents structural data for S-27.

ADCP measurements were taken at structure S-27 on November 19, 1994, March 29, 1995, and June 22,1995 (table 2). All of the measurements were taken at the measurement section shown in figure 14. Data for submerged weir flow were collected on all three dates. Both gates were lifted on November 19, 1994, and June 22, 1995, but on March 29, 1995, only one gate was lifted. Additionally, on March 29, 1995, data were collected for submerged orifice flow by opening the gate at 3, 4,6, and $8 \mathrm{ft}$. Logarithmic and linear scale plots of the discharge-coefficient ratings for the submerged orifice- and submerged weir-flow regimes are shown in figure 15.

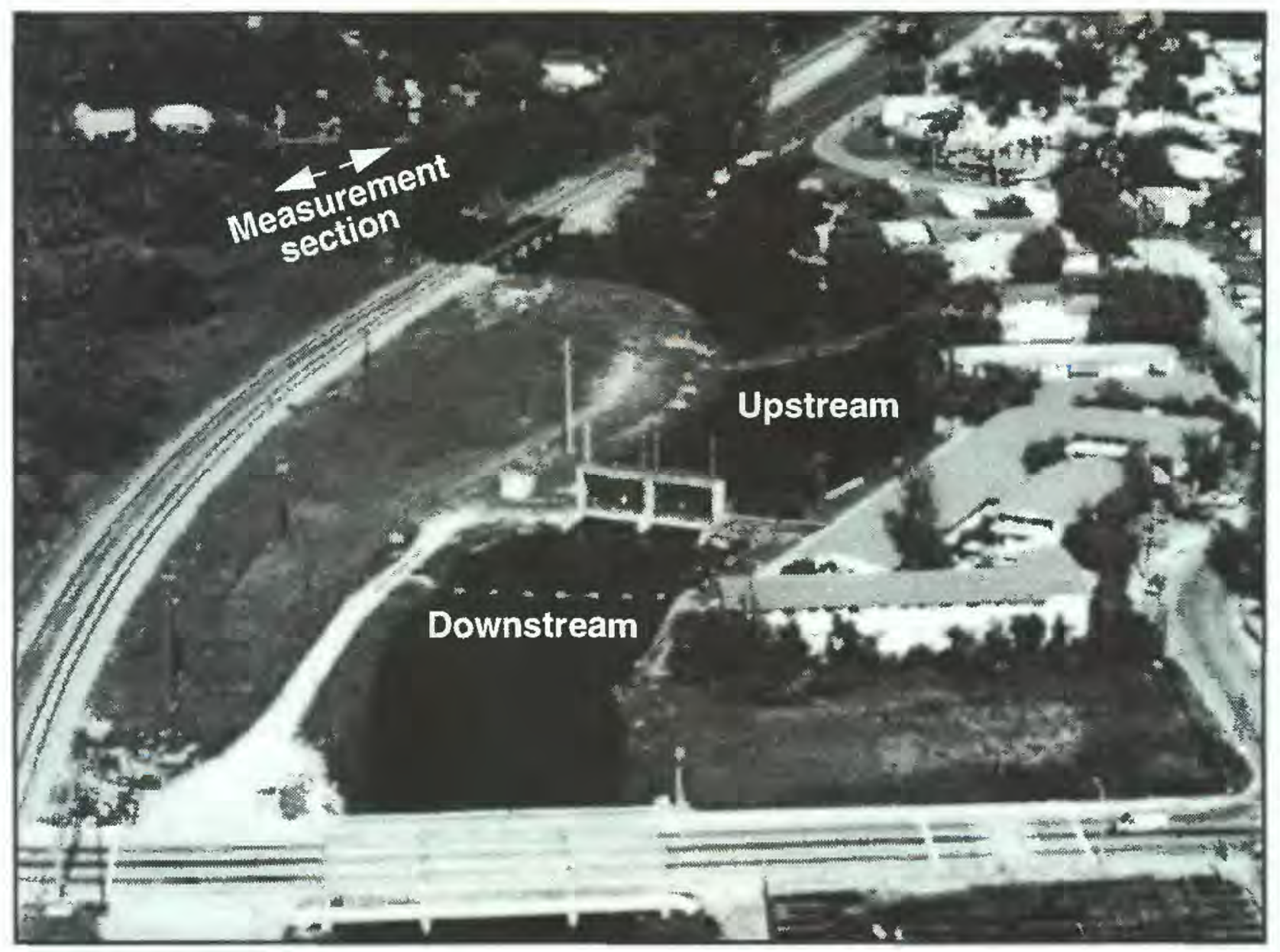

Figure 14. Structure S-27. 

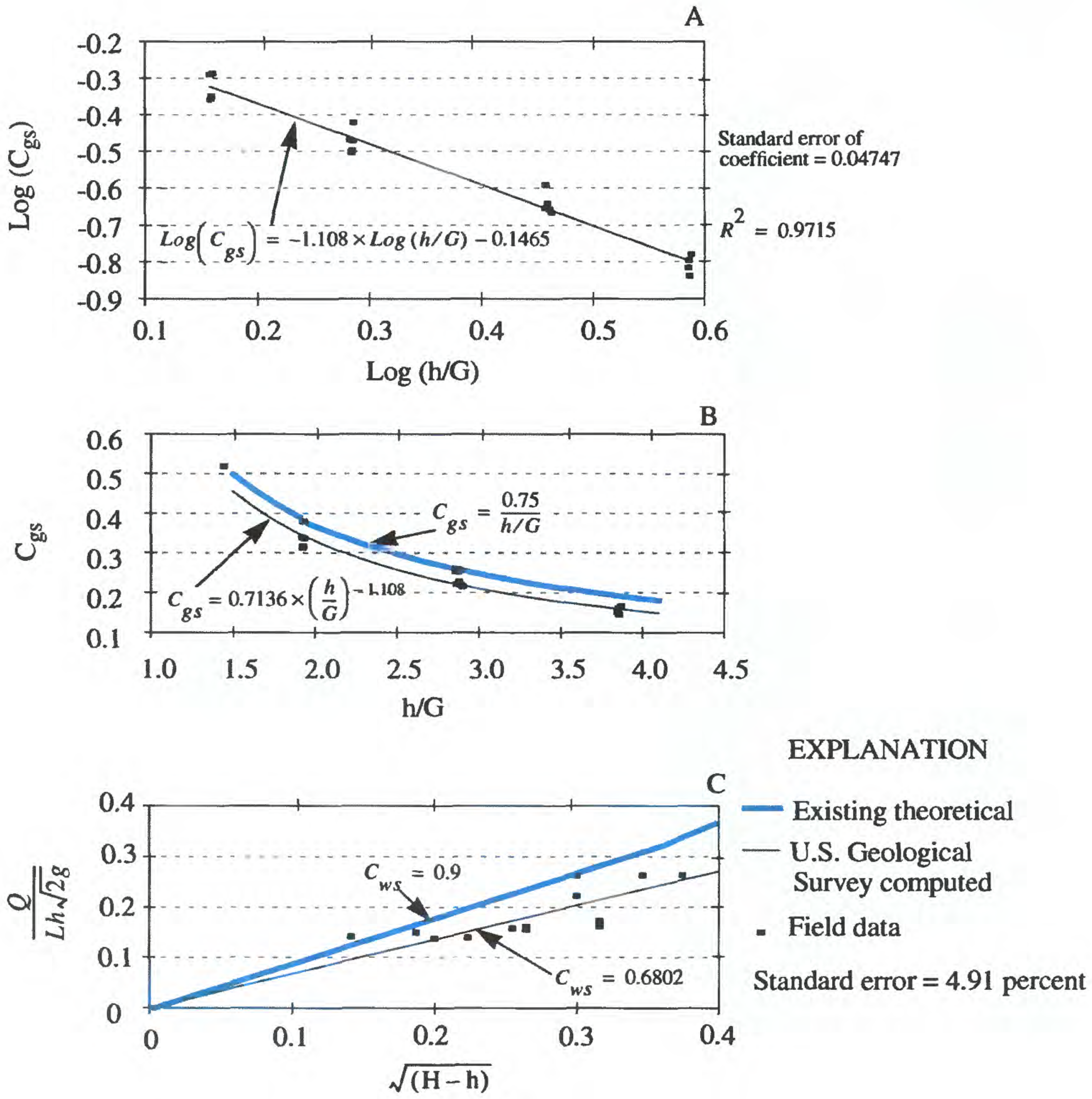

Figure 15. Logarithmic plot of the S-27 discharge coefficierit for submerged orifice flow (graph A) and linear scale plots of a comparisorı of the S-27 discharge coefficierit for submerged orifice flow (graph B) and submerged weir flow (graph C). Arı explariation of the mathematical symbols is giverı irl appendix III. 
The flow through structure S-27 was computed for 1994 using both the theoretical- and computedcoefficient ratings as shown in figure 16 . The ratings are very similar; however, flows were low and there was no significant weir flow. The total flow for 1994 using the theoretical-coefficient rating is 103,528 acre$\mathrm{ft}$, and the total flow using the computed-coefficient rating is 93,277 acre- $\mathrm{ft}$. The volumes differ by about 11.0 percent. Some negative flows were allowed at structure S-27.

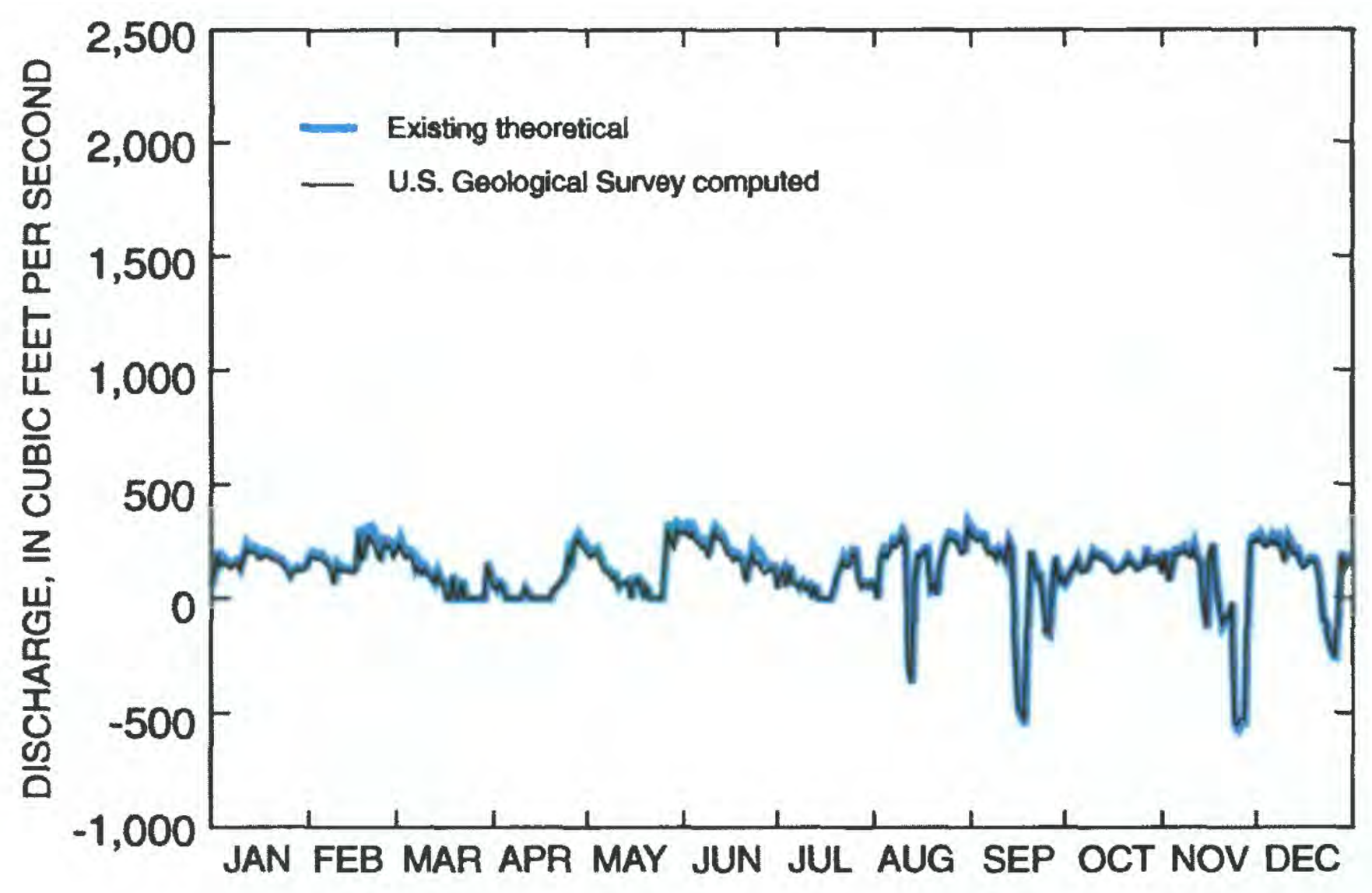

Figure 16. Theoretical and computed flows for structure S-27 in 1994. 


\section{Structure S-26}

Structure S-26 (fig. 17) is a reinforced-concrete gated spillway with discharge controlled by two cableoperated, vertical lift gates. This coastal structure is located at the N.W. 36th Street crossing of the C-6 canal (Miami Canal) in Miami (fig. 1). Structure S-26 maintains optimum water-control stages upstream in the C- 6 canal and prevents saltwater intrusion during periods of high tide. Additionally, structure S-26 passes the design flood (100 percent of the SPF) without exceeding upstream flood design stage criteria set by water managers and restricting downstream flood stages and discharge velocities to nondamaging levels. The automatic controls on this coastal structure have an overriding mechanism that closes the gates, regardless of the upstream water level in the event of high tide, when the differential between the falling headwater and rising tailwater pool elevations reaches $0.3 \mathrm{ft}$. A timing device that prevents sudden gate closing has been installed to protect manatees during automatic gate operation. Appendix I presents flood discharge characteristics for structure S-26, and appendix II presents structural data for S-26.

ADCP measurements were taken at structure S-26 on March 28, 1995 (table 2), at the measurement section located about $300 \mathrm{ft}$ upstream of the coastal structure (fig. 17). One of two gates was opened at 1,2 and $3 \mathrm{ft}$ to obtain data for submerged orifice flow, and the same gate was lifted to obtain data for submerged weir flow. The other gate was closed for all measurements. Logarithmic and linear scale phots of the discharge-coefficient ratings for the submerged orificeand submerged weir-flow regimes are shown in figure 18.

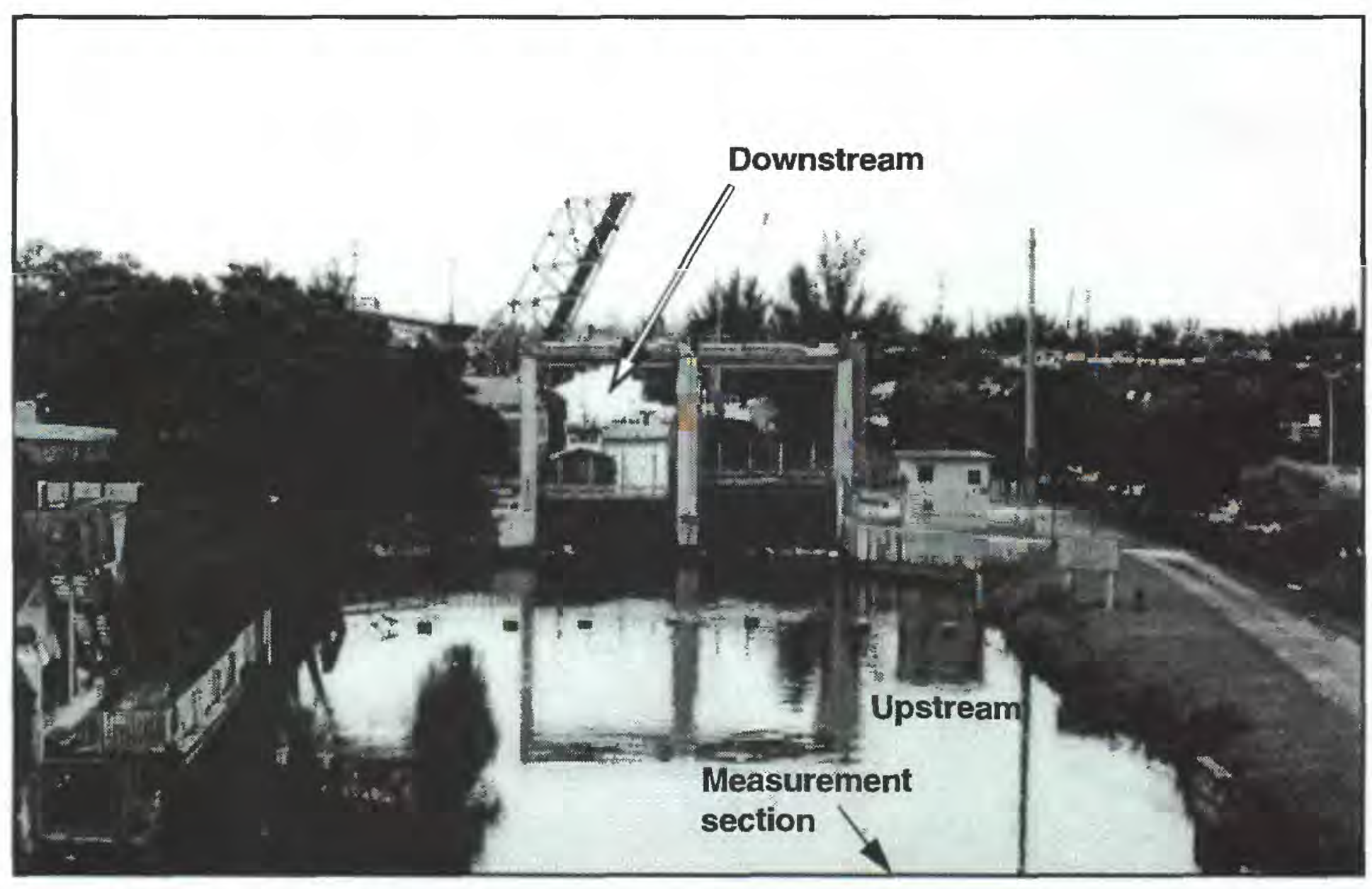

Figure 17. Structure S-26. 


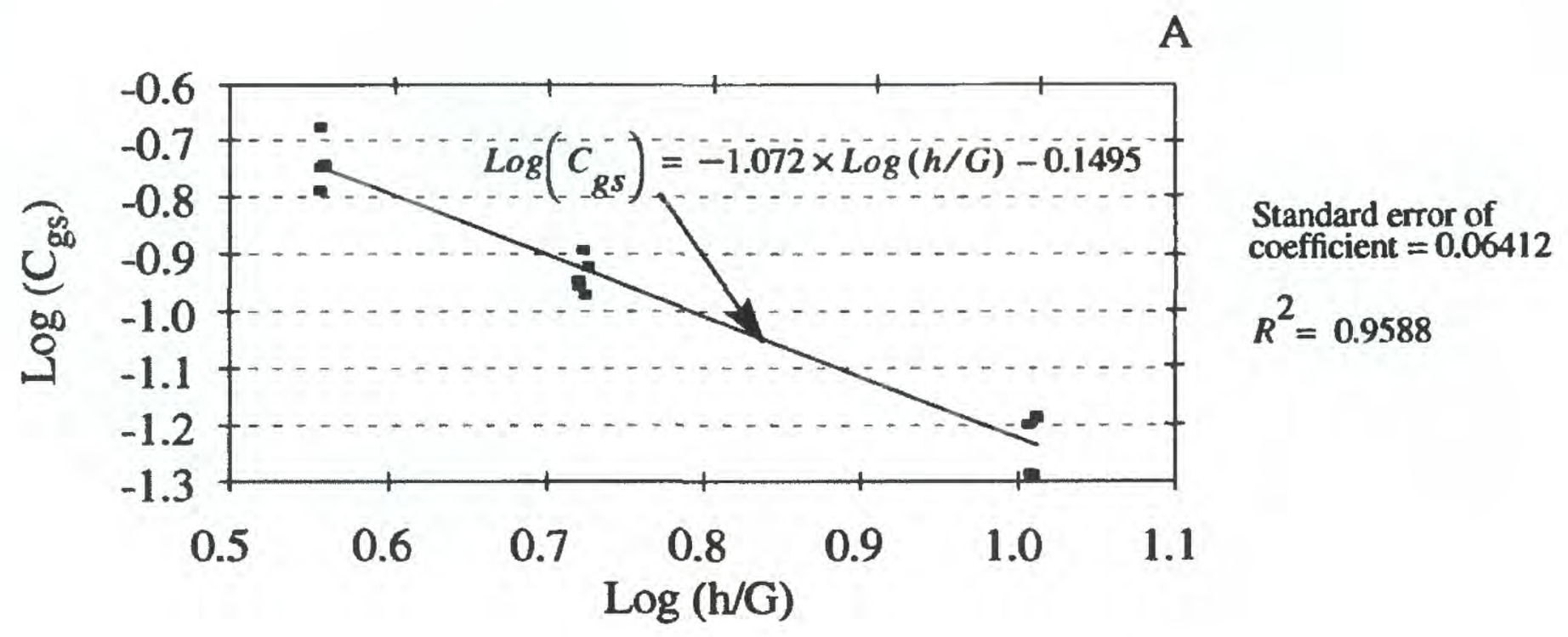

B

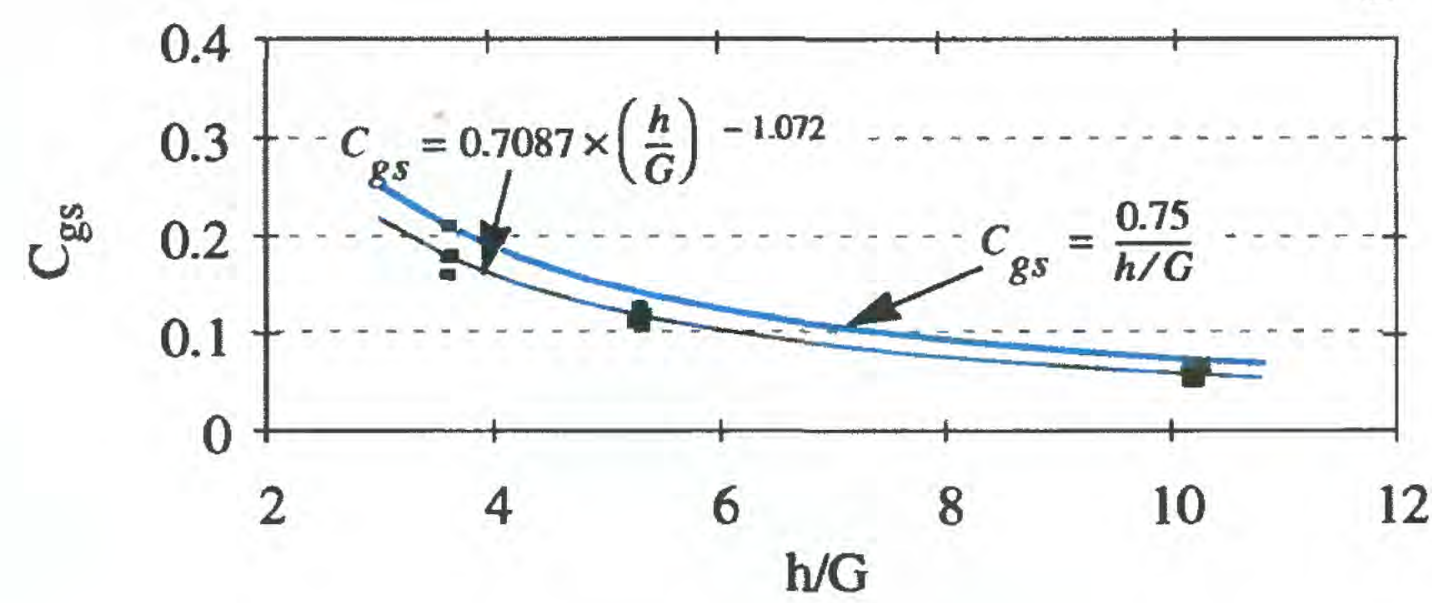

C EXPLANATION

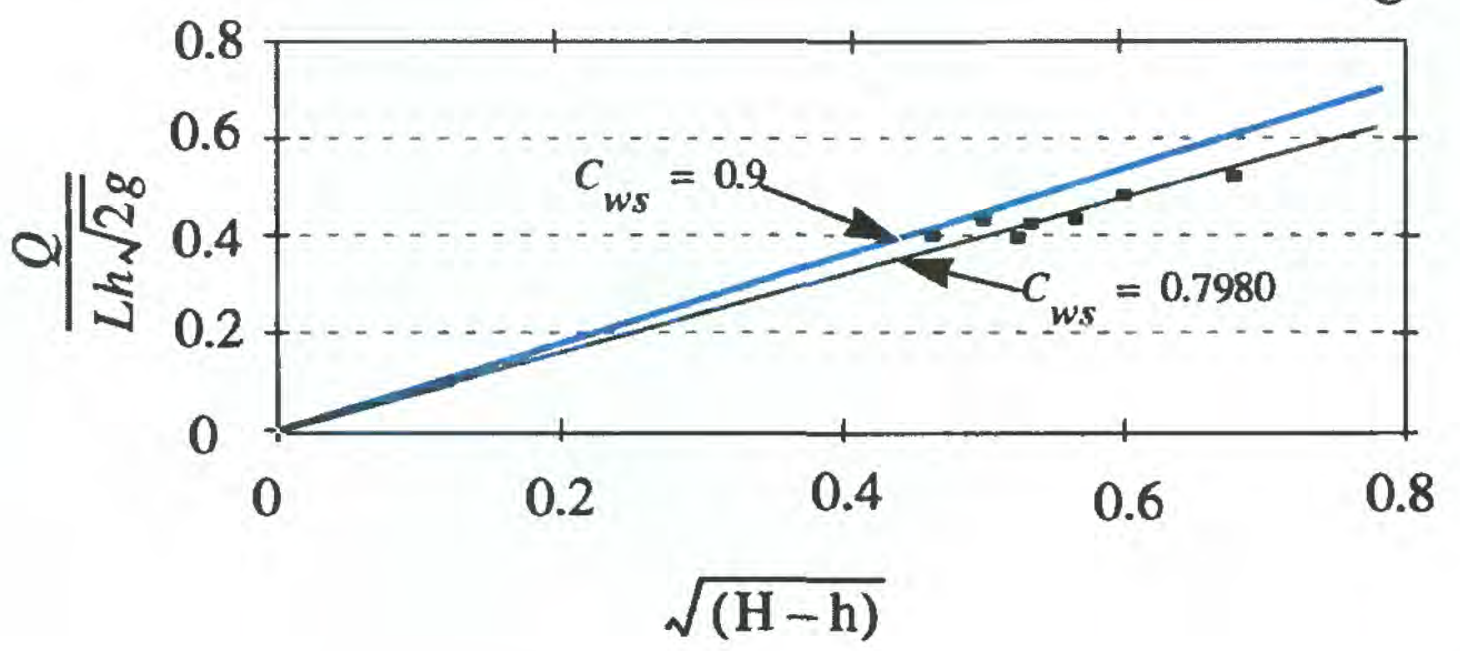

— Existing theoretical

- U.S. Geological survey computed

- Field data

Standard error $=1.98$ percent

Figure 18. Logarithmic plot of the S-26 discharge coefficient for submerged orifice flow (graph A) and linear scale plots of a comparison of the S-26 discharge coefficient for submerged orifice flow (graph B) and submerged weir flow (graph C). An explanation of the mathematical symbols is given in appendix III. 
The flow through structure S-26 was computed for 1994 using both the theoretical- and computedcoefficient ratings as shown in figure 19. Significant differences are apparent at higher flow rates with the computed-coefficient rating showing less flow. The total flow for 1994 using the theoretical-coefficient rating is 143,142 acre- $\mathrm{ft}$, and the total flow using the computed-coefficient rating is 124,702 acre-ft. The volumes differ by about 14.8 percent. Some negative flows were allowed at structure S-26.

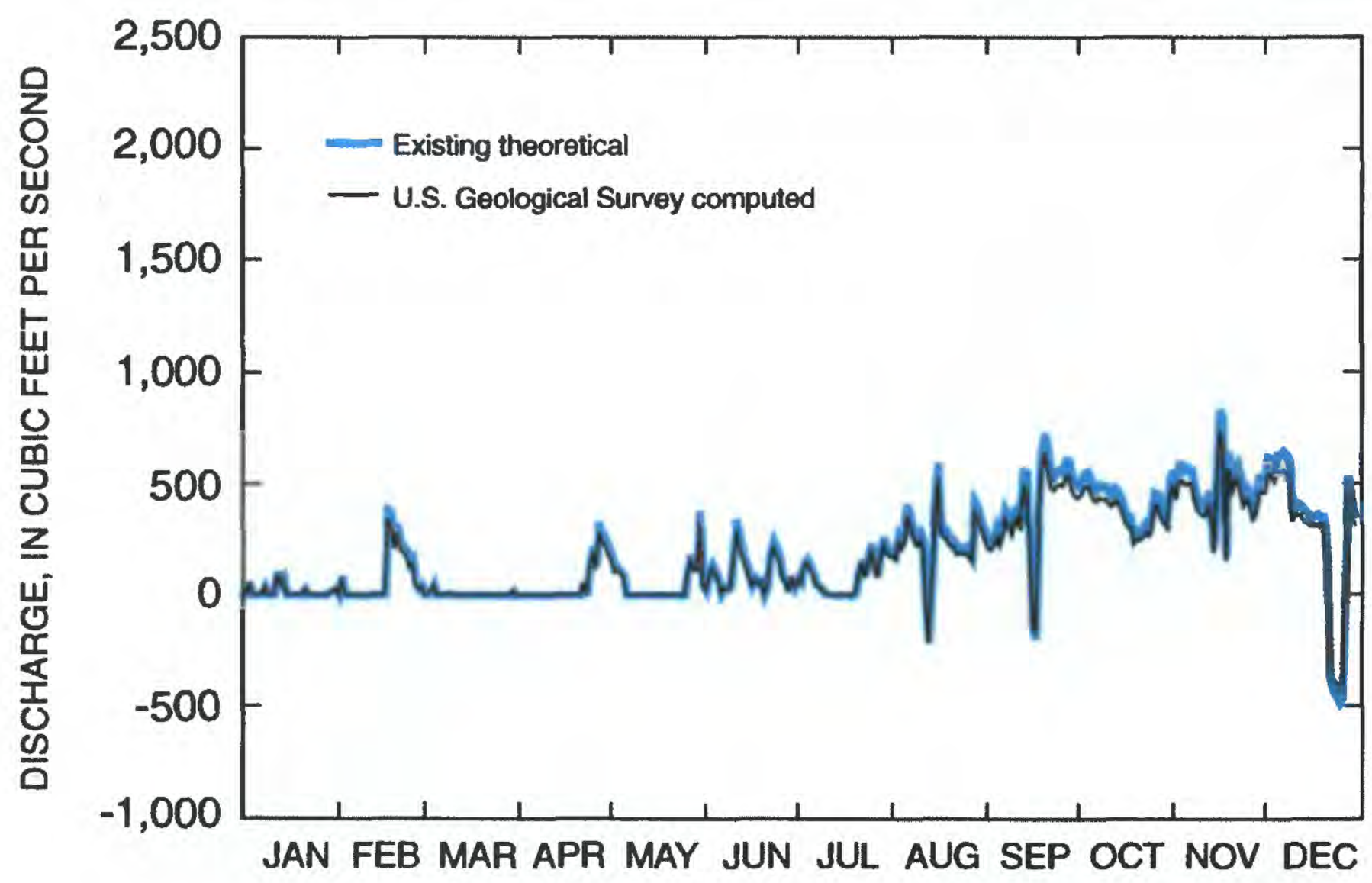

Figure 19. Theoretical and computed flows for structure S-26 in 1994. 


\section{Structure S-25B}

Structure S-25B (fig. 20) is a reinforced-concrete gated spillway with discharge controlled by two cableoperated, vertical lift gates. This coastal structure is located immediately downstream of the Le Jeune Road crossing of the $\mathrm{C}-4$ canal (Tamiami Canal) in Miami (fig. 1). Structure S-25B maintains optimum watercontrol stages upstream in the $\mathrm{C}-4$ canal and prevents saltwater intrusion during periods of high tide. Additionally, structure $S-25 B$ passes the design flood (100 percent of the SPF) without exceeding upstream flood design stage criteria set by water managers and restricting downstream flood stages and discharge velocities to nondamaging levels. The automatic controls on this coastal structure have an overriding mechanism that closes the gates, regardless of the upstream water level in the event of high tide, when the differential between the falling headwater and rising tailwater pool elevations reaches $0.3 \mathrm{ft}$. A timing device that prevents sudden gate closing has been installed to protect manatees during automatic gate operation. Appendix I presents flood discharge characteristics for structure S-25B, and appendix II presents structural data for S-25B.

ADCP measurements were taken at structure S-25B on November 20, 1994, December 11, 1994, and March 29, 1995 (table 2). All of the measurements were taken at the measurement section shown in figure 20. Data for submerged weir flow were collected on November 20,1994, with two gates open. Data for submerged orifice flow were collected on December 11, 1994, and March 29, 1995. On December 11, 1994, two gates were opened at $0.95,2.0,2.5,3.0,3.5,4.0,5.1$, and $6.0 \mathrm{ft}$. On March 29, 1995, one gate was opened at $1,2,3,4,5$, and $6 \mathrm{ft}$, and the second gate was opened at 1,2 , and $3 \mathrm{ft}$. Both gates were opened simultaneously at 1,2, and $3 \mathrm{ft}$. Logarithmic and linear scale plots of the discharge-coefficient ratings for the submerged orifice- and submerged weir-flow regimes are shown in figure 21 .

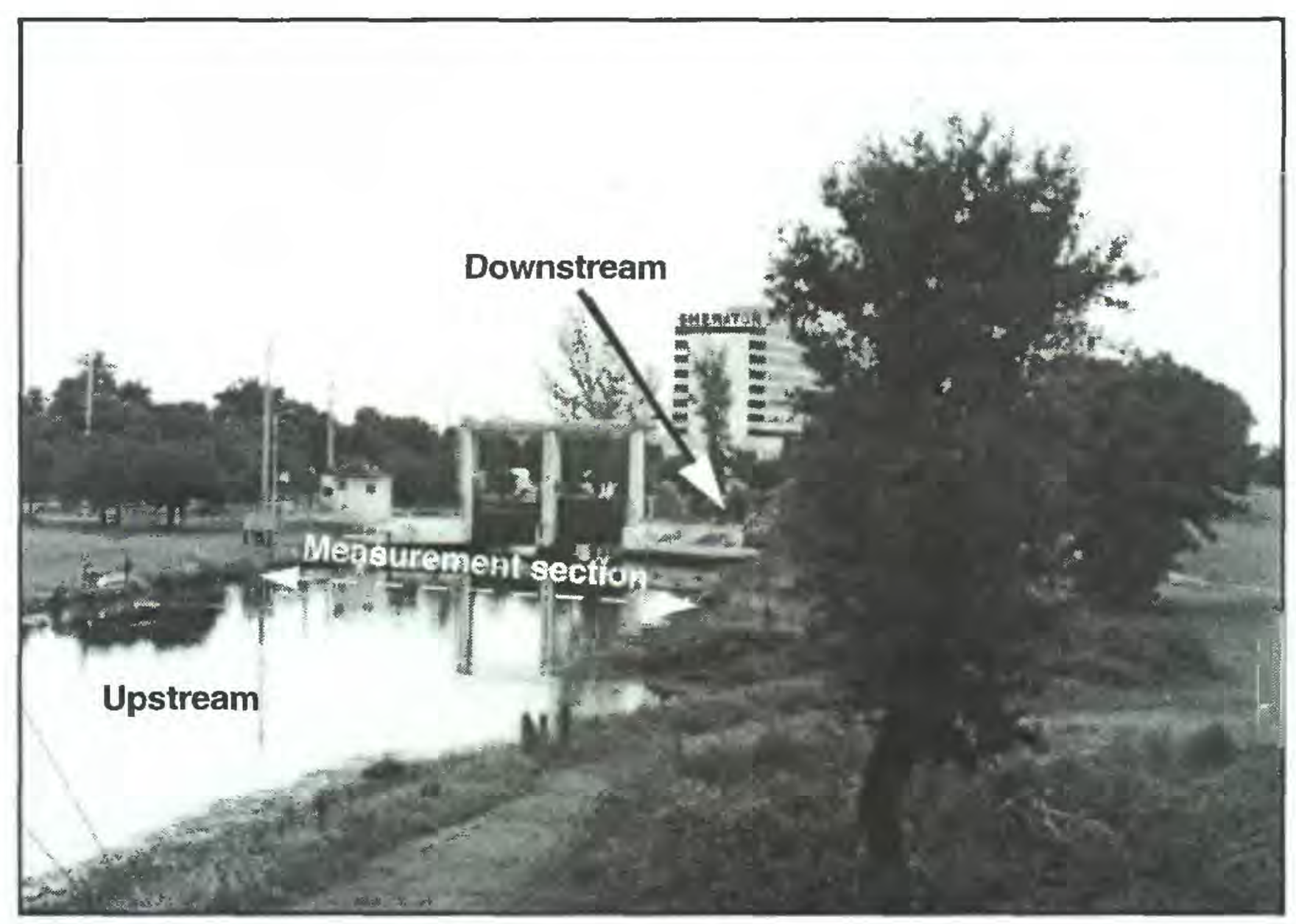

Figure 20. Structure S-25B. 

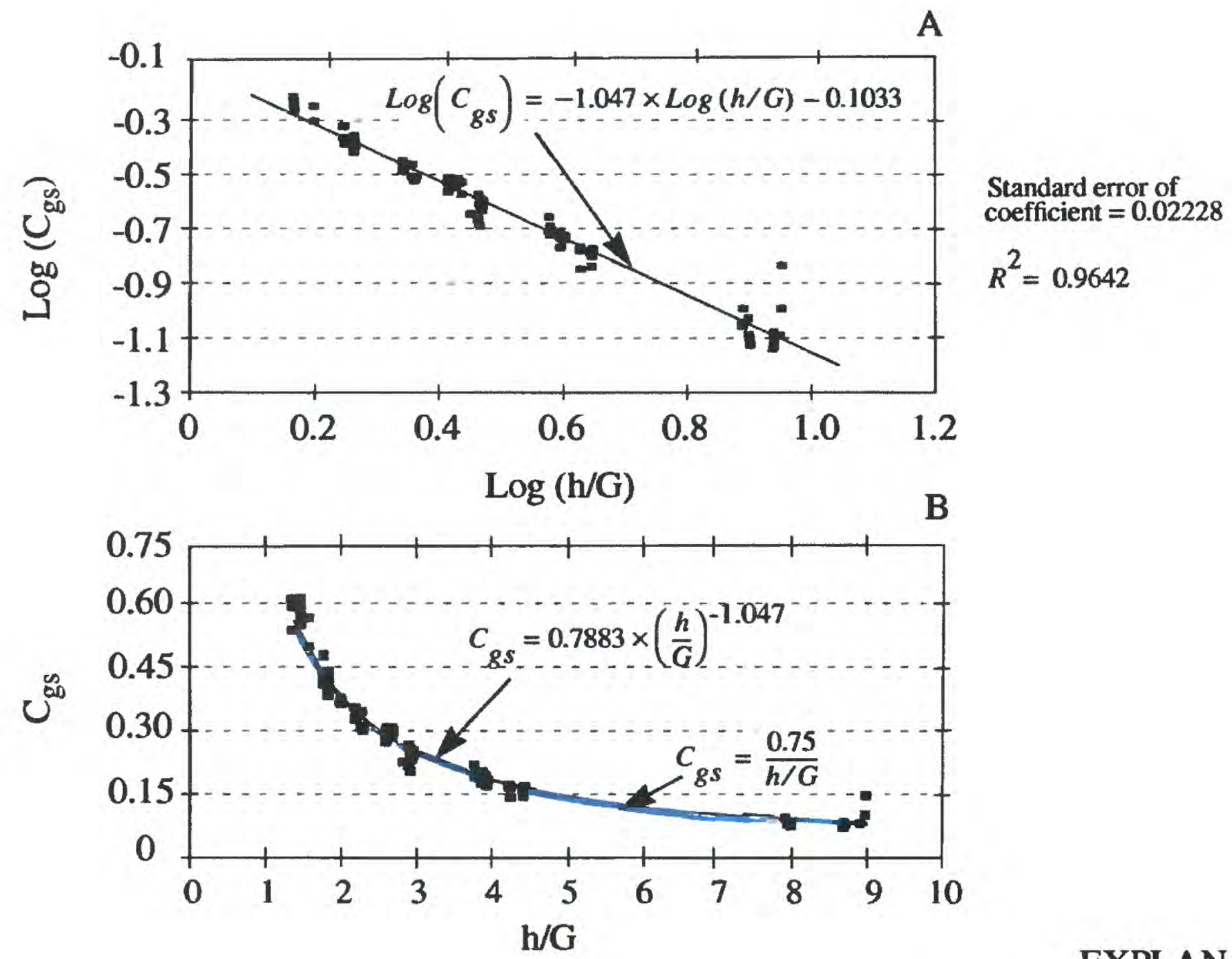

\section{EXPLANATION}

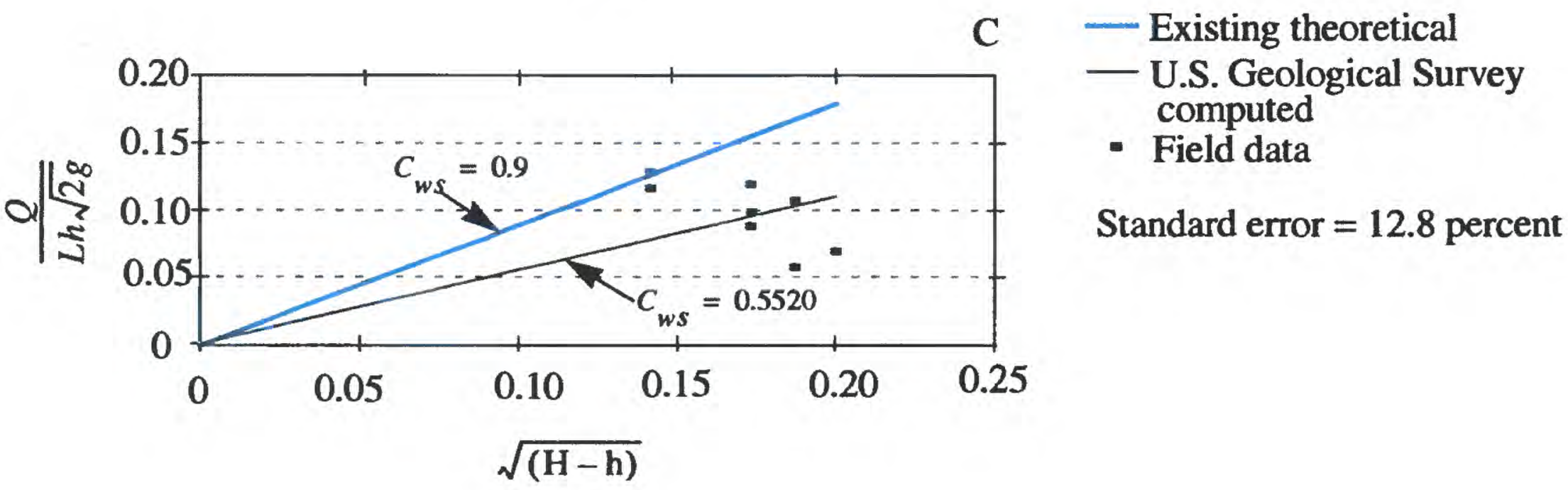

Figure 21. Logarithmic plot of the S-25B discharge coefficient for submerged orifice flow (graph A) and linear scale plots of a comparison of the S-25B discharge coefficient for submerged orifice flow (graph B) and submerged weir flow (graph C). An explanation of the mathematical symbols is given in appendix III. 
The flow through structure S-25B was computed for 1994 using both the theoretical- and computedcoefficient ratings as shown in figure 22 . Because the submerged orifice rating is very close to the theoreticalcoefficient rating, the hydrograph comparison is very similar with the most significant deviation occurring at the highest weir flow. The total flow for 1994 using the theoretical-coefficient rating is 177,335 acre- $\mathrm{ft}$, and the total flow using the computed-coefficient rating is 183,919 acre-ft. The volumes differ by about 3.6 percent. Some negative flows were allowed at structure S-25B.

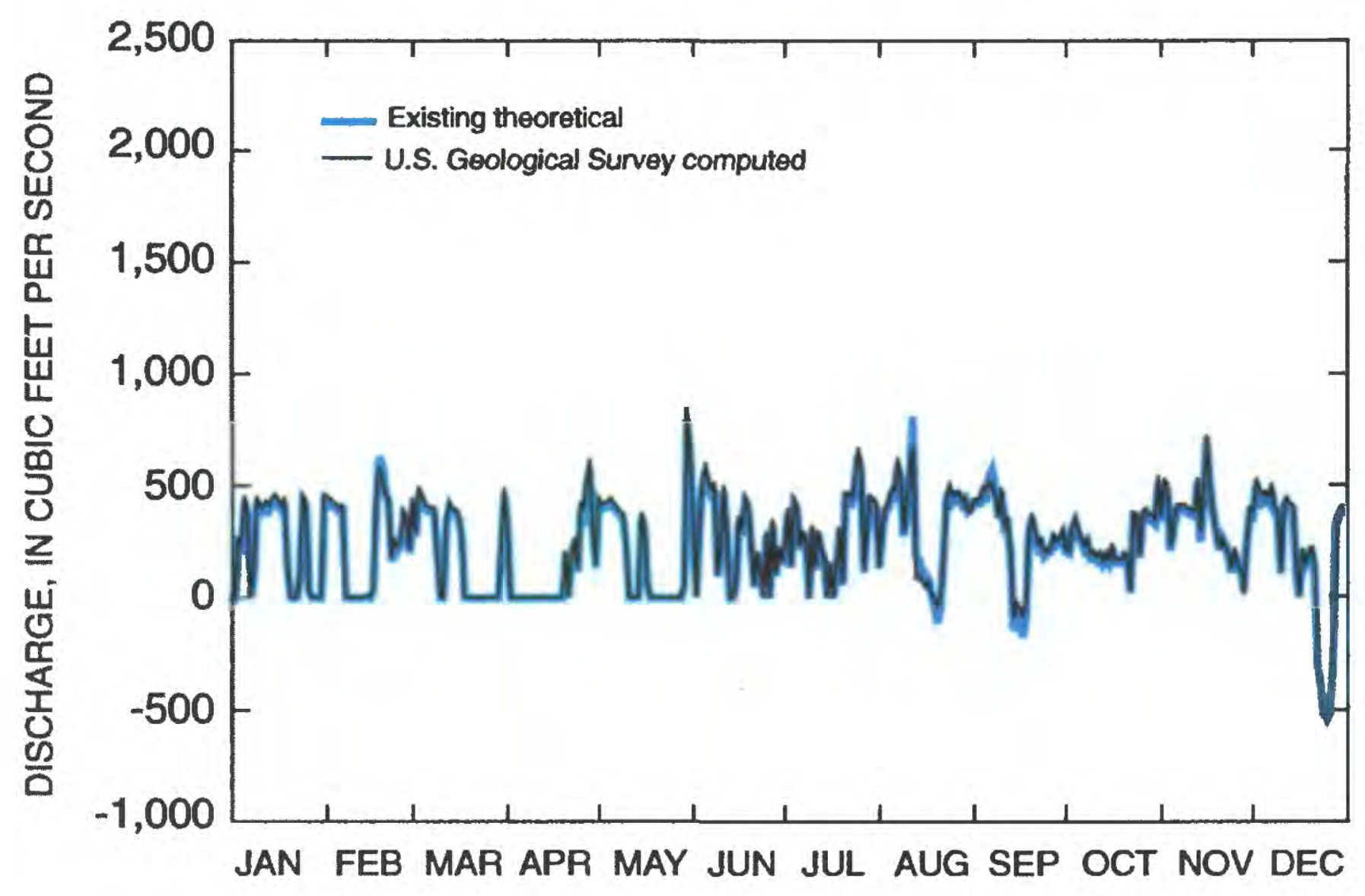

Figure 22. Theoretical and computed flows for structure S-25B in 1994. 


\section{Structure S-25}

Structure S-25 (fig. 23) is a single-barrel corrugated-metal-pipe culvert with discharge controlled by a circular sluice gate. This nontelemetric coastal structure is located at the N.W. 27th Avenue crossing of the C-5 canal (Comfort Canal) in Miami (fig. 1). Structure S-25 maintains optimum water-control stages upstream in the $\mathrm{C}-5$ canal and prevents saltwater intrusion during periods of high tide. Additionally, structure $\mathrm{S}-25$ passes the design flood (10-year recurrence interval) without exceeding upstream flood design stage criteria set by water managers and restricting downstream flood stages and discharge velocities to nondamaging levels. The automatic controls on this coastal structure have an overriding mechanism that closes the gates, regardless of the upstream water level in the event of high tide, when the differential between the falling headwater and rising tailwater pool elevations reaches $0.2 \mathrm{ft}$. Appendix I presents flood discharge characteristics for structure S-25, and appendix II presents structural data for S-25.

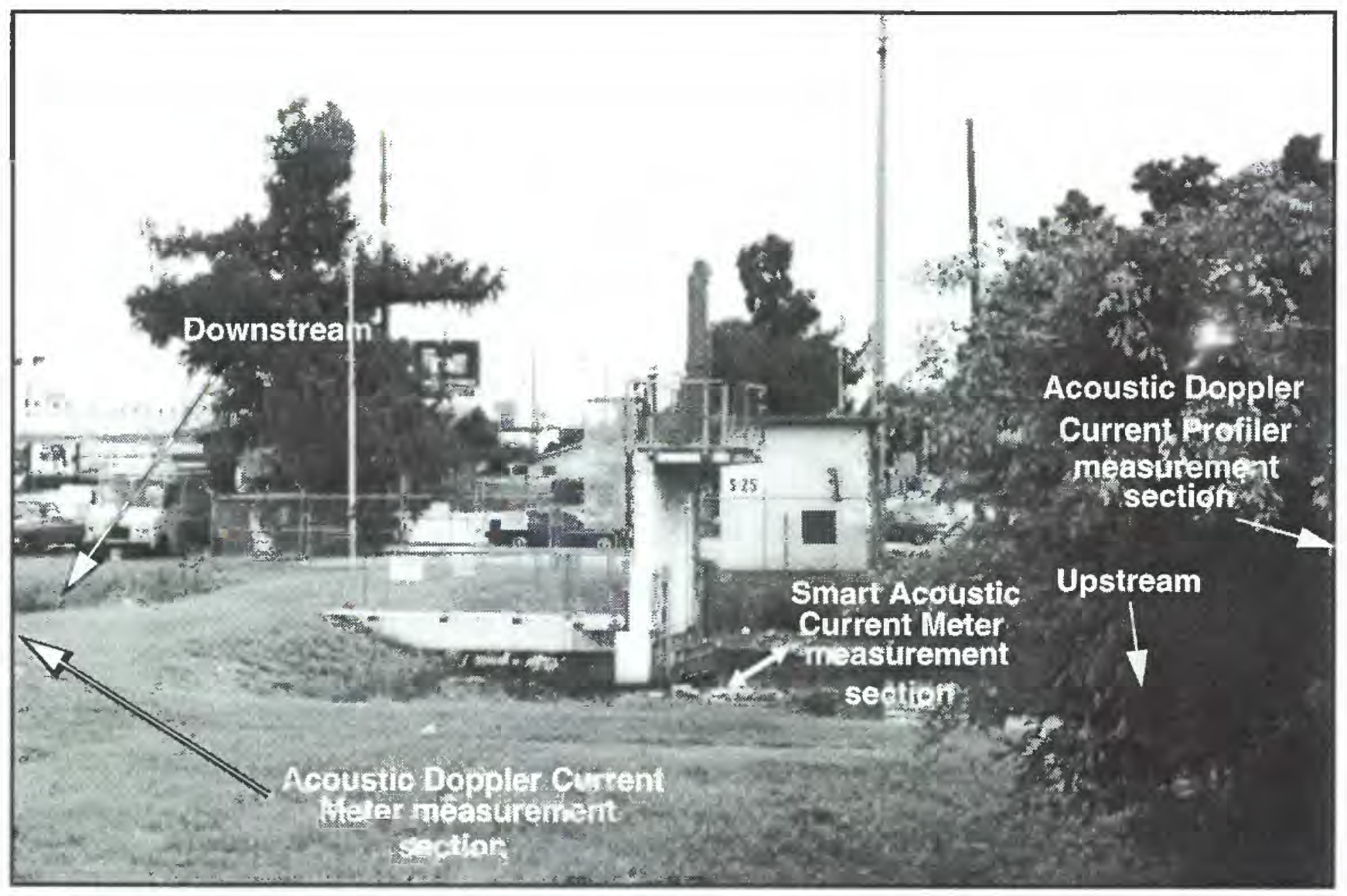

Figure 23. Structure S-25. 
Flow measurements were taken at structure S-25 using both the ADCP and SACM (table 2). On March 28,1995 , the ADCP was employed about $50 \mathrm{ft}$ downstream of the coastal structure and the SACM was employed immediately upstream of the coastal structure as shown in figure 23. The SACM was successful in measuring the flows (the discharge-coefficient rating is shown in fig. 24). Unfortunately, the ADCP could not obtain accurate readings at the downstream measuring section (fig. 23) because the flows were extremely low, somewhat turbulent, and exhibited salinity gradients. On September 21, 1995, flow measurements were attempted again using the ADCP, about $100 \mathrm{ft}$ upstream of the coastal structure (fig. 23), but were once again inaccurate. Flows were not only extremely low, but the canal was overgrown with weeds. Measurements were taken at the mouth of the culvert where flow patterns are more predictable.

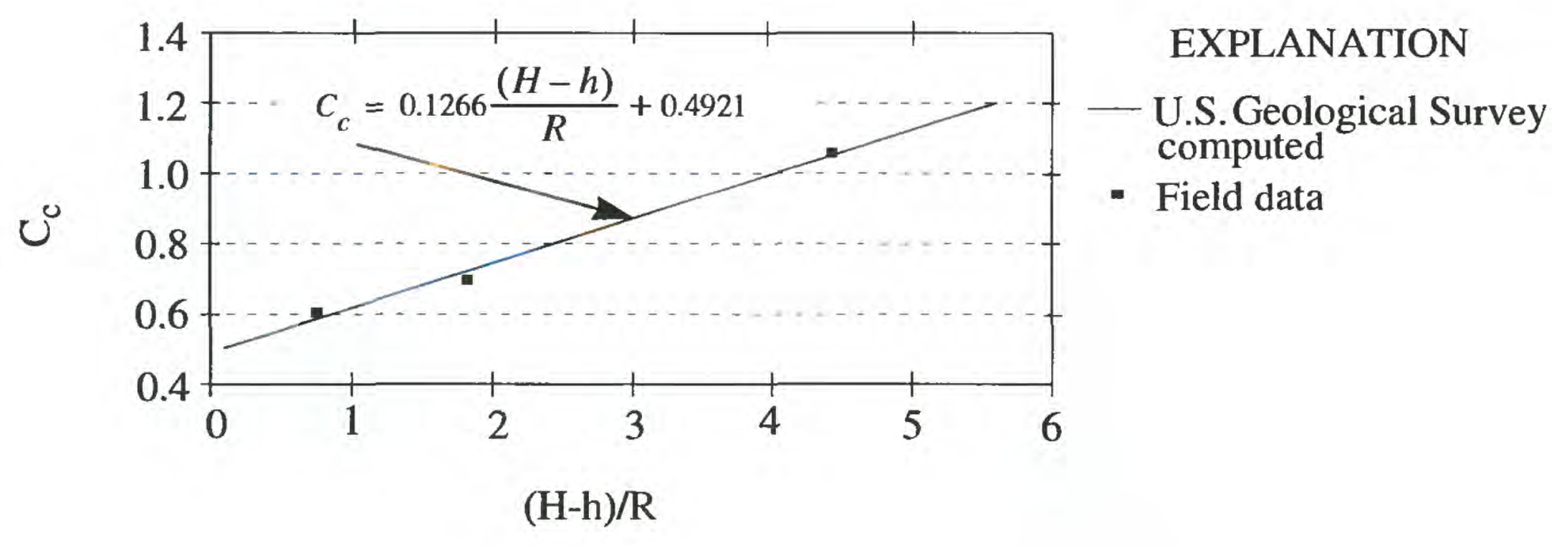

Figure 24. Linear scale plot of the discharge coefficient for the S-25 gated culvert. An explanation of the mathematical symbols is given in appendix Iil. 


\section{Structure G-93}

Structure G-93 (fig. 25) is a reinforced-concrete gated spillway with discharge controlled by two vertical lift gates. This nontelemetric coastal structure is located on the C-3 canal (Coral Gables Canal) at Red Road in Miami (fig. 1). Structure G-93 maintains optimum water-control stages upstream in the C-3 canal and prevents saltwater intrusion during periods of high tide. Additionally, structure G-93 passes the design flood flows, resulting from a 10-year storm (about 40 percent of the SPF), plus a small discharge from the C-4 canal without exceeding upstream flood design stage criteria set by water managers and restricting downstream flood stages and discharge velocities to nondamaging levels. Operation of the gates is manually controlled, and there is no automatic timing device to prevent injury to manatees. Appendix I presents flood discharge characteristics for structure G-93, and appendix II presents structural data for G-93.
ADCP measurements were taken at structure G-93 on March 24, 1995, March 27, 1995, and June 22, 1995 (table 2). All of the measurements were taken at two measurement sections - one about $60 \mathrm{ft}$ and the other about $120 \mathrm{ft}$ upstream of the coastal structure (fig. 25). On March 24, 1995, data were collected for submerged orifice flow with one gate opened at 1 and $2 \mathrm{ft}$ and two gates opened simultaneously at 1,2 , and $3 \mathrm{ft}$. On March 27, 1995, data were collected for both submerged orifice and weir flows. One gate was opened at 1 and $2 \mathrm{ft}$, and two gates were opened simultaneously at 1 and $2 \mathrm{ft}$ to obtain data for submerged orifice flow. Both gates were also opened to obtain data for submerged weir flow. On June 22, 1995, several measurements of submerged weir flow were taken by opening two gates. Logarithmic and linear scale plots of the discharge-coefficient ratings for the submerged orificeand submerged weir-flow regimes are shown in figure 26.

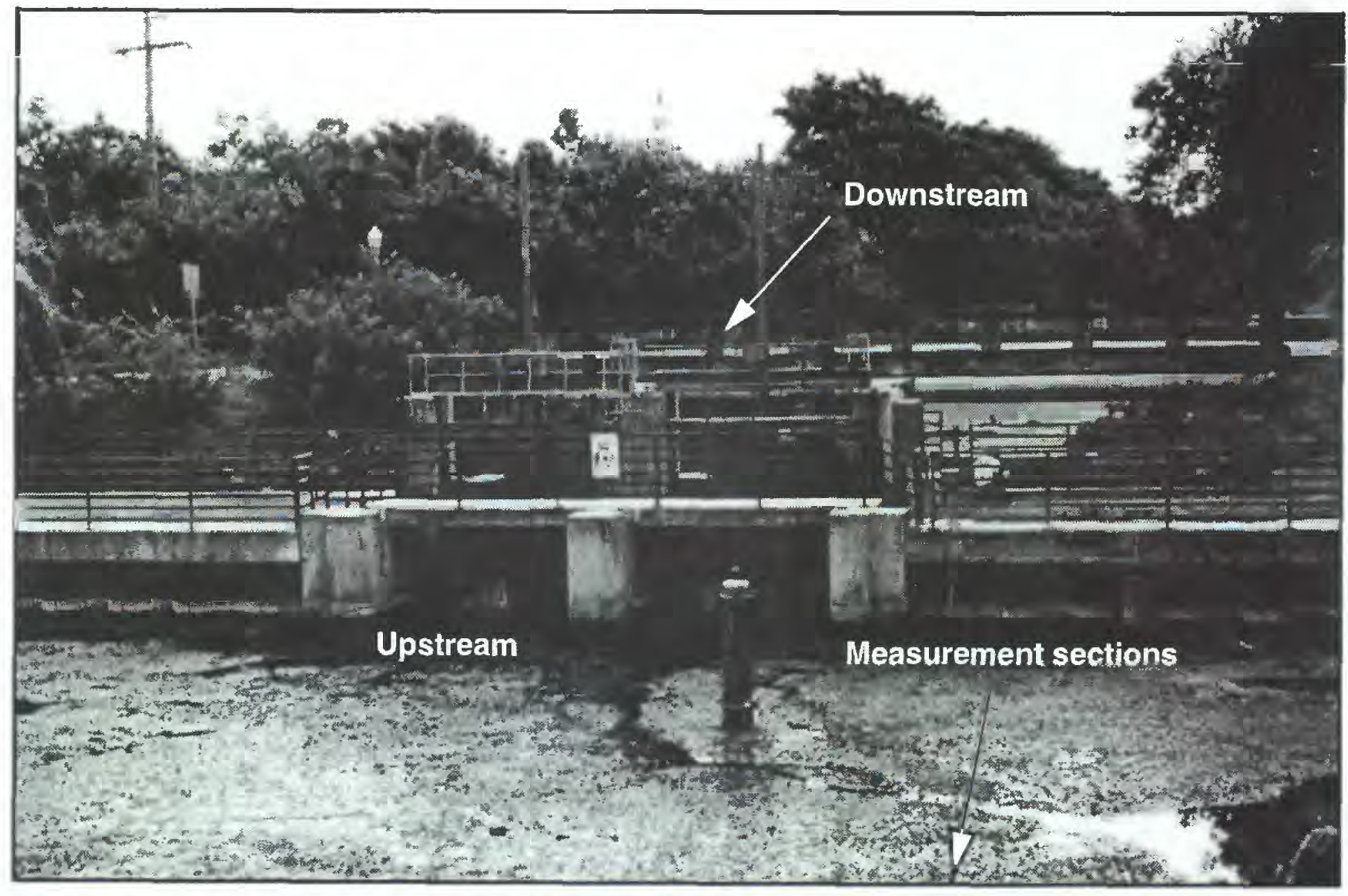

Figure 25. Structure G-93. 

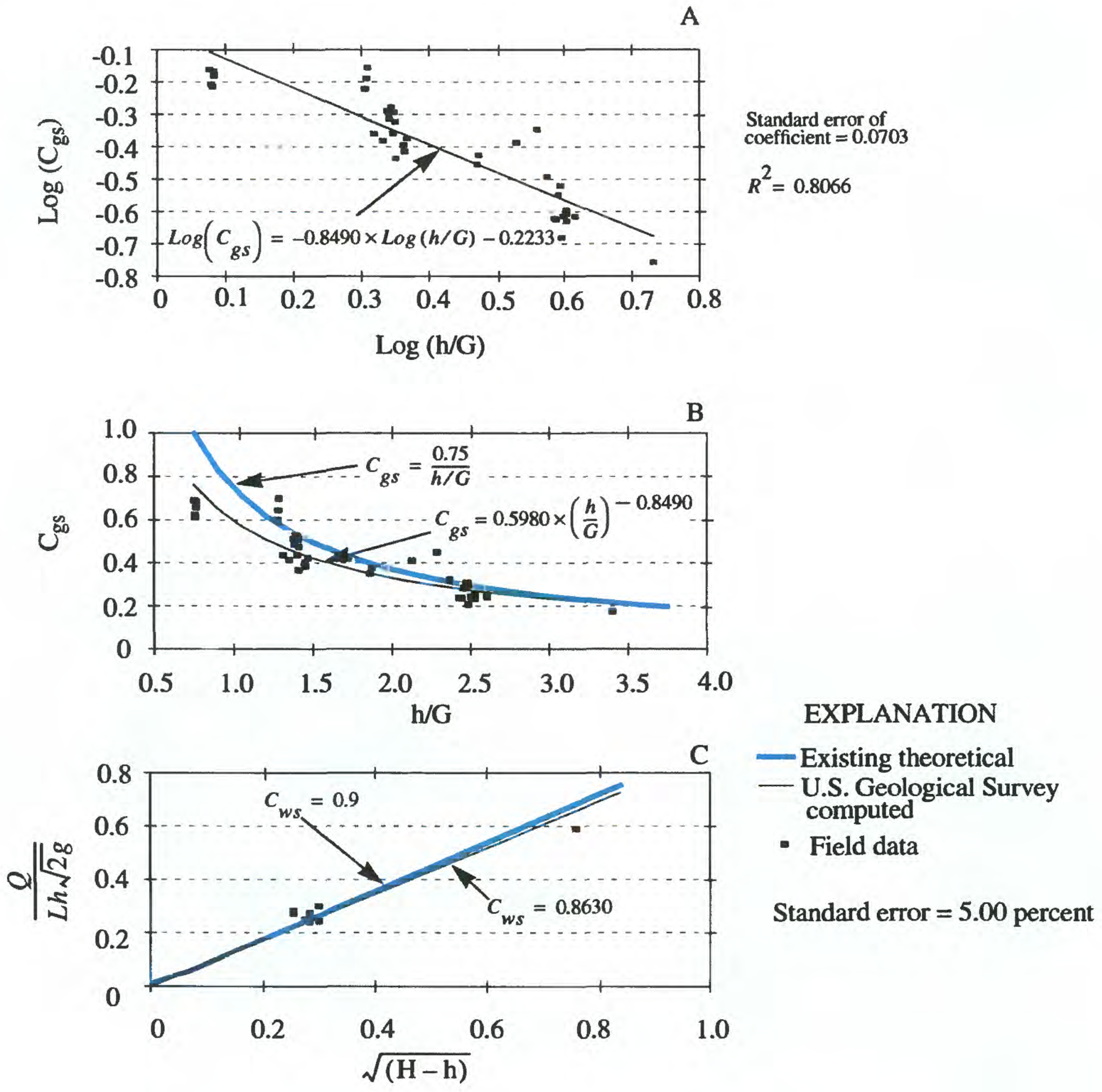

Figure 26. Logarithmic plot of the G-93 discharge coefficient for submerged orifice flow (graph A) and linear scale plots of a comparison of the G-93 discharge coefficient for submerged orifice flow (graph B) and submerged weir flow (graph C). An explanation of the mathematical symbols is given in appendix III. 


\section{Structure S-22}

Structure S-22 (fig. 27) is a reinforced-concrete gated spillway with discharge controlled by two cableoperated, vertical lift gates. This coastal structure is located in Miami near the mouth of the C-2 canal (Snapper Creek Canal) and is about $1.3 \mathrm{mi}$ from Biscayne Bay (fig. 1). Structure S-22 maintains optimum water-control stages upstream in the $\mathrm{C}-2$ canal and prevents saltwater intrusion during periods of high tide. Additionally, structure $\mathrm{S}-22$ passes the design flood (100 percent of the SPF) without exceeding upstream flood design stage criteria set by water managers and restricting downstream flood stages and discharge velocities to nondamaging levels. The automatic controls on this coastal structure have an overriding mechanism that closes the gates, regardless of the upstream water level in the event of high tide, when the differential between the falling headwater and rising tailwater pool elevations reaches $0.3 \mathrm{ft}$. A timing device that prevents sudden gate closing has been installed to protect manatees during automatic gate operation. Appendix I presents flood discharge characteristics for structure S-22, and appendix II presents structural data for S-22.

ADCP measurements were taken at structure S-22 on March 30, 1995 (table 2), at the measurement section shown in figure 27. Data were collected for submerged orifice flow, with one gate opened at $1,2,3$, 4, 6 and $8 \mathrm{ft}$ and two gates opened simultaneously at $\mathbf{1}$, 2 , and $4 \mathrm{ft}$. Data were collected for submerged weir flow by opening one gate. Logarithmic and linear scale plots of the discharge-coefficient ratings for the submerged orifice- and submerged weir-flow regimes are shown in figure 28 .

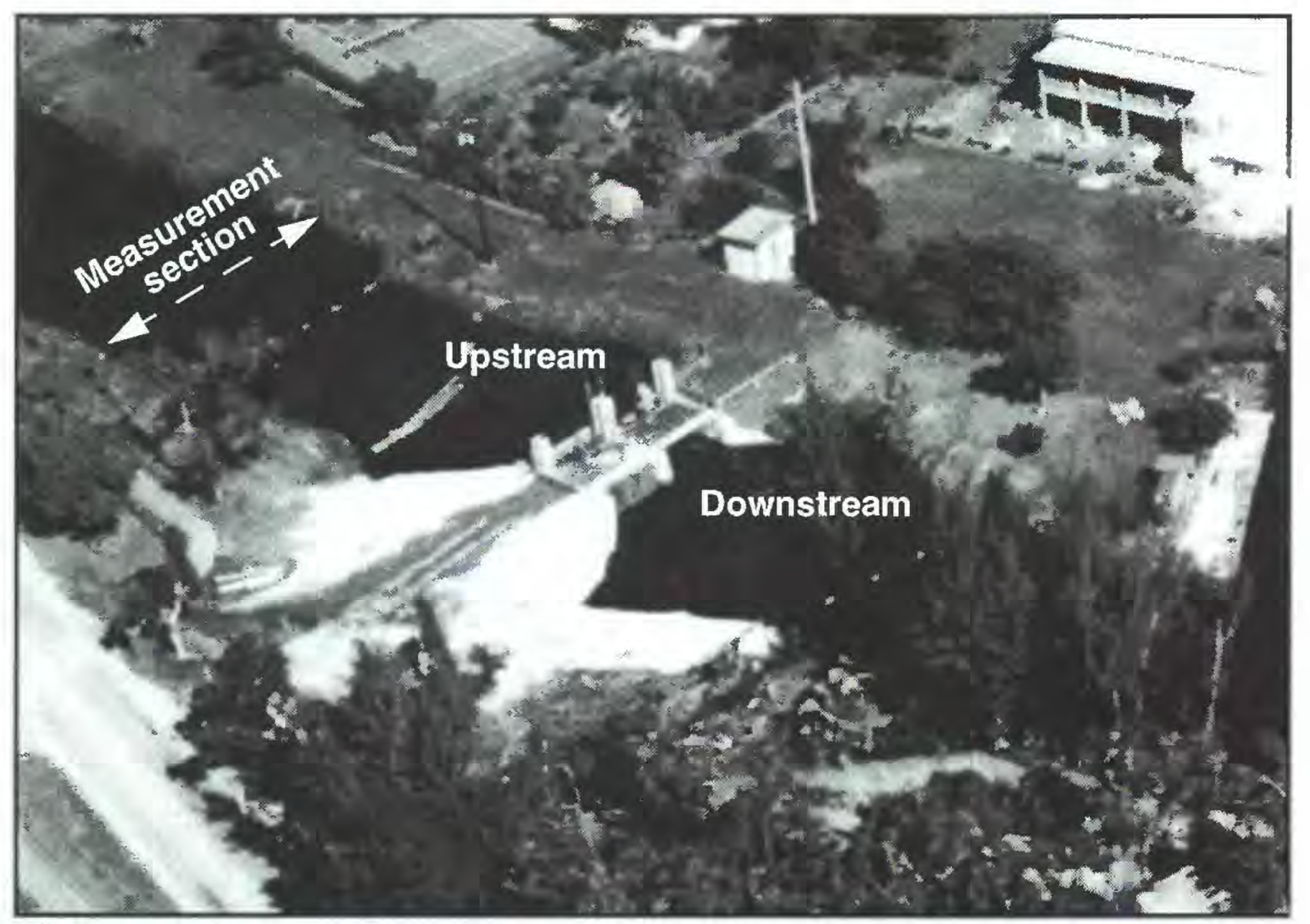

Figure 27. Structure S-22. 


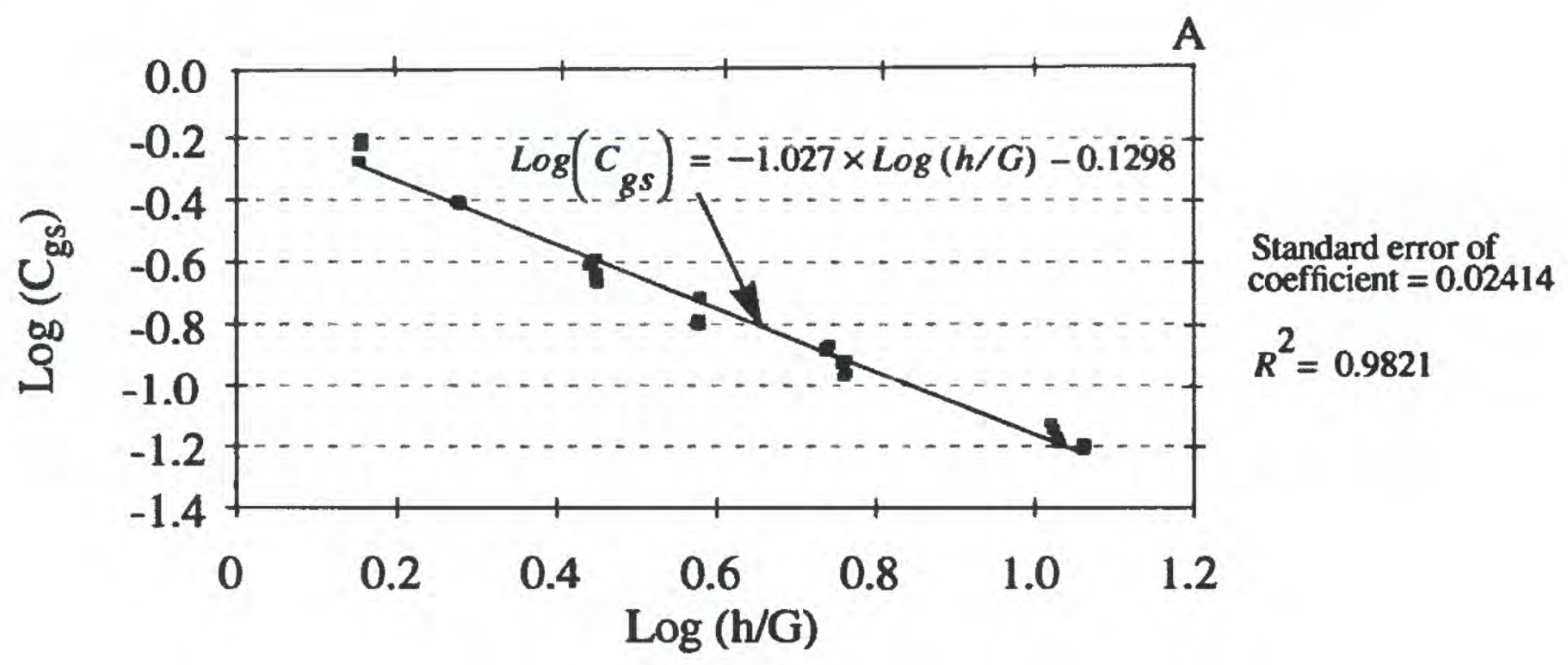

B
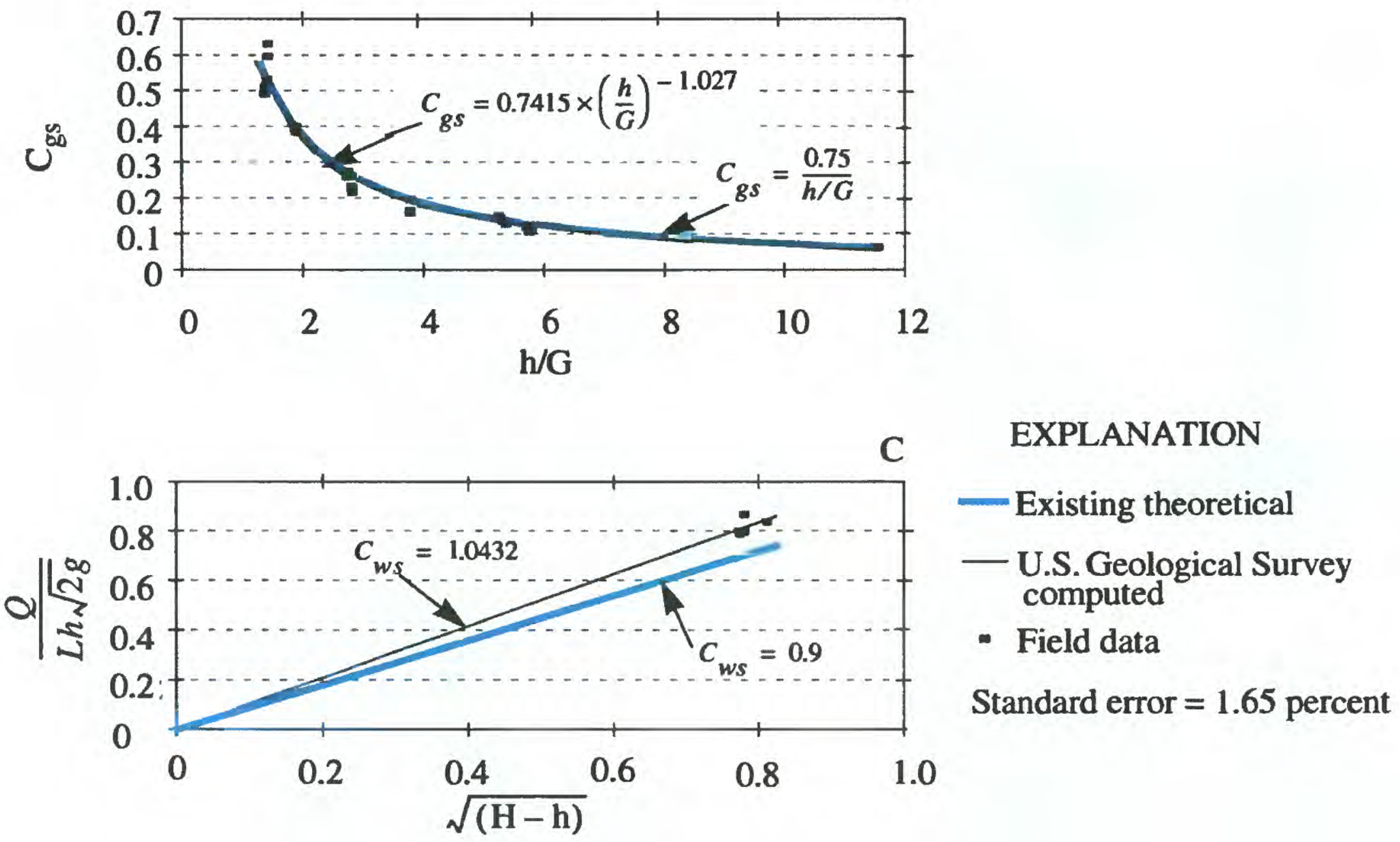

Figure 28. Logarithmic plot of the S-22 discharge coefficient for submerged orifice flow (graph A) and linear scale plots of a comparison of the S-22 discharge coefficient for submerged orifice flow (graph B) and submerged weir flow (graph C). An explanation of the mathematical symbols is given in appendix III. 
The flow through structure $\mathrm{S}-22$ was computed for 1994 using both the theoretical- and computedcoefficient ratings as shown in figure 29 . The hydrograph comparison is very close because the ratings are very similar. The total flow for 1994 using the theoretical-coefficient rating is 164,447 acre- $\mathrm{ft}$, and the total flow using the computed-coefficient rating is 167,995 acre-ft. The volumes differ by about 2.1 percent.

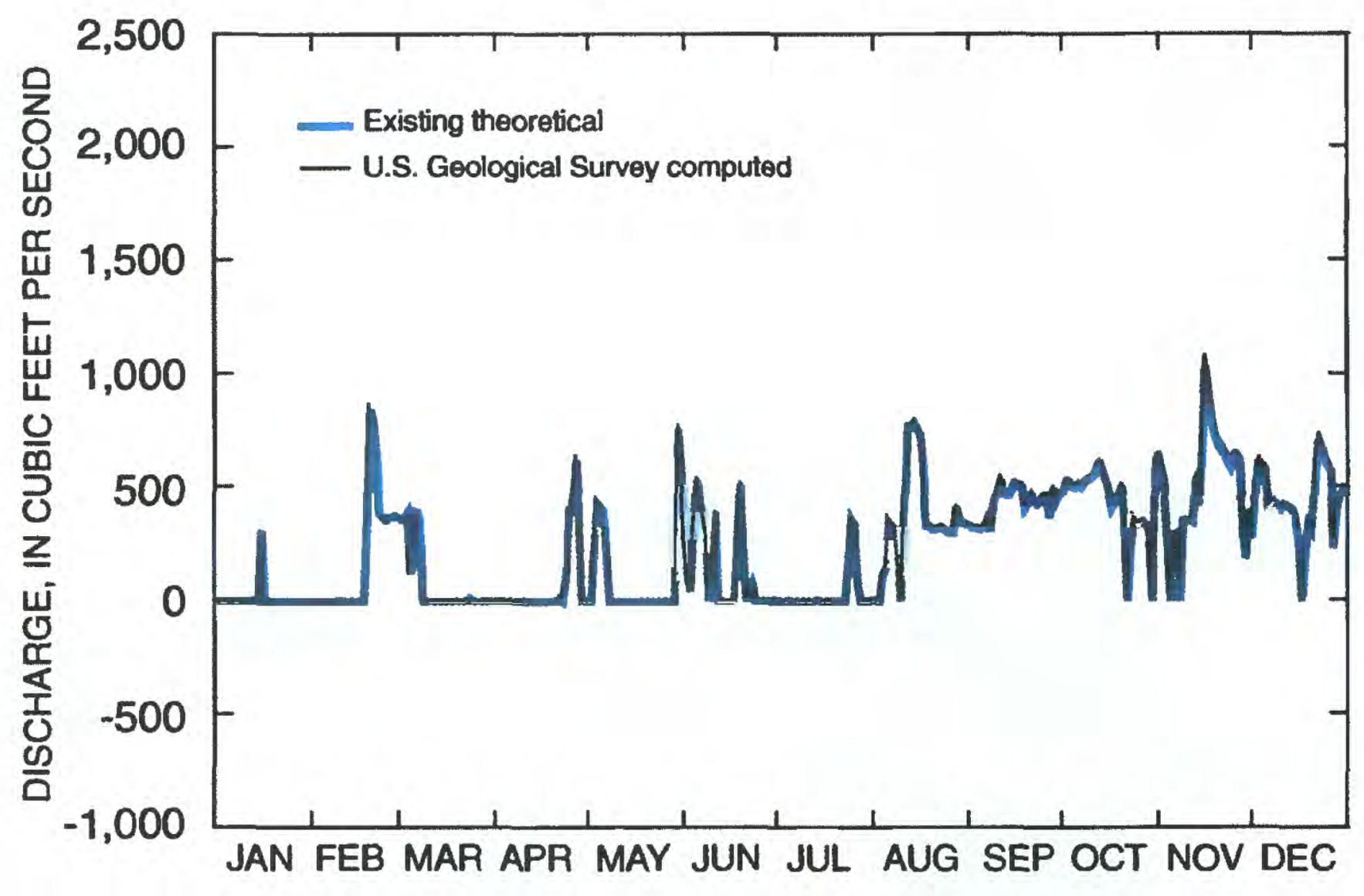

Figure 29. Theoretical and computed flows for structure S-22 in 1994. 


\section{Structure S-123}

Structure S-123 (fig. 30) is a reinforced-concrete gated spillway with discharge controlled by two cableoperated, vertical lift gates. This coastal structure is located in Miami near the mouth of the $\mathrm{C}-100$ canal (Cutler Drain Canal) below the junction of the C-100, $\mathrm{C}-100 \mathrm{~A}$, and C-100B canals and is about $600 \mathrm{ft}$ from Biscayne Bay (fig. 1). Structure S-123 maintains optimum water-control stages upstream in the C-100, C-100A, and C-100B canals and prevents saltwater intrusion during periods of high tide. Additionally, structure $S-123$ passes the design flood (40 percent of the SPF) without exceeding upstream flood design stage criteria set by water managers and restricting downstream flood stages and discharge velocities to nondamaging levels. The automatic controls on this coastal structure have an overriding mechanism that closes the gates, regardless of the upstream water level in the event of high tide, when the differential between the falling headwater and rising tailwater pool elevations reaches $0.3 \mathrm{ft}$. A timing device that prevents sudden gate closing has been installed to protect manatees during automatic gate operation. Appendix I presents flood discharge characteristics for structure S-123, and appendix II presents structural data for S-123.

ADCP measurements were taken at structure S-123 on March 21, 1995, and September 20, 1995 (table 2), at the two measurement sections shown in figure 30. One ADCP was used to take measurements on March 21, 1995, and two ADCP's were used to take measurements on September 20, 1995. On March 21, 1995, data were collected for submerged orifice flow with one gate opened at 1,2 , and $4 \mathrm{ft}$ and two gates opened simultaneously at 1, 2, 3, and $4 \mathrm{ft}$. On September 20,1995 , one gate was opened at $6 \mathrm{ft}$ to obtain data for submerged orifice flow, and the same gate was opened to obtain data for submerged weir flow. Logarithmic and linear scale plots of the discharge-coefficient ratings for the submerged orifice- and submerged weir-flow regimes are shown in figure 31 .

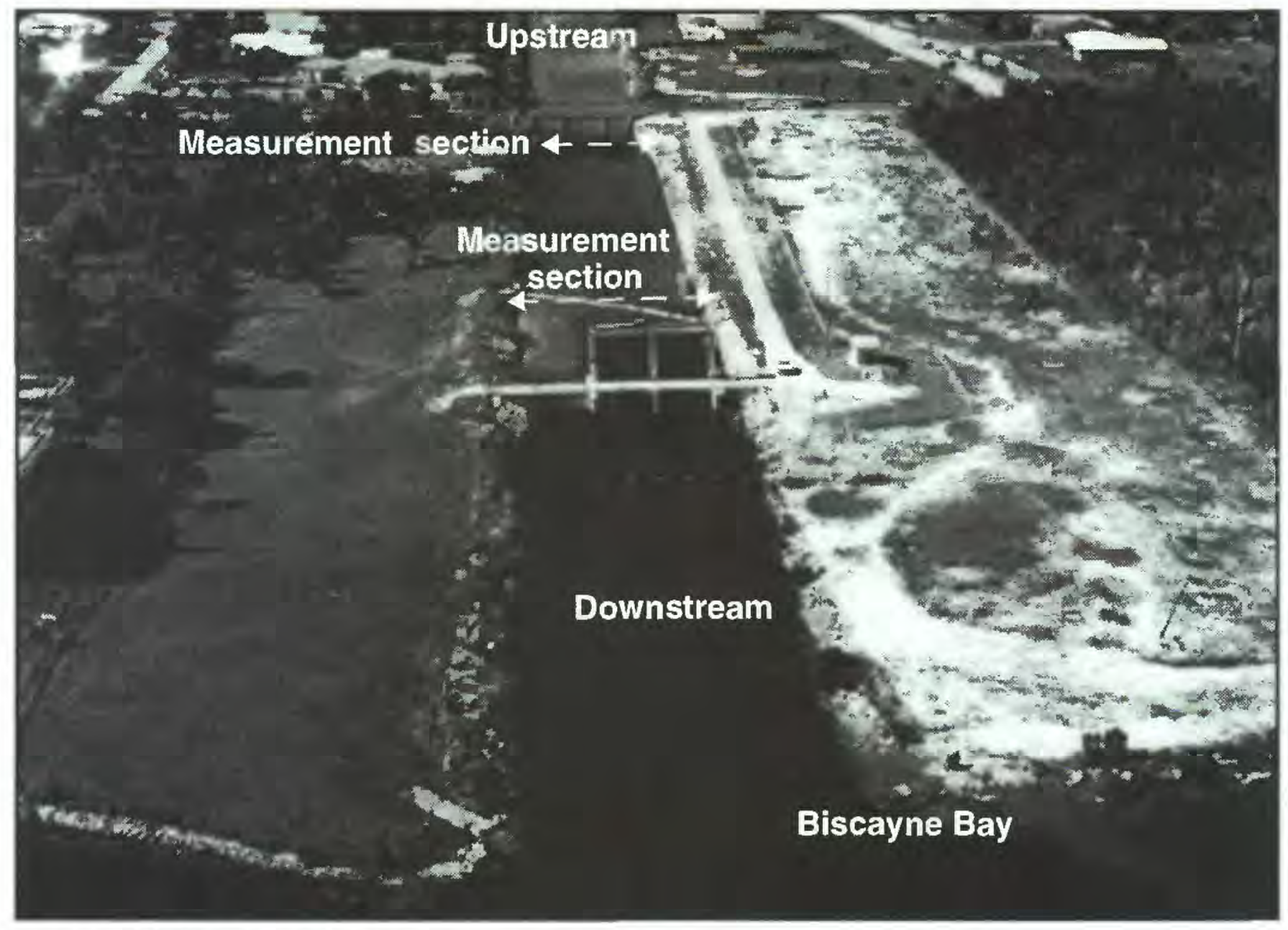

Figure 30. Structure S-123. 

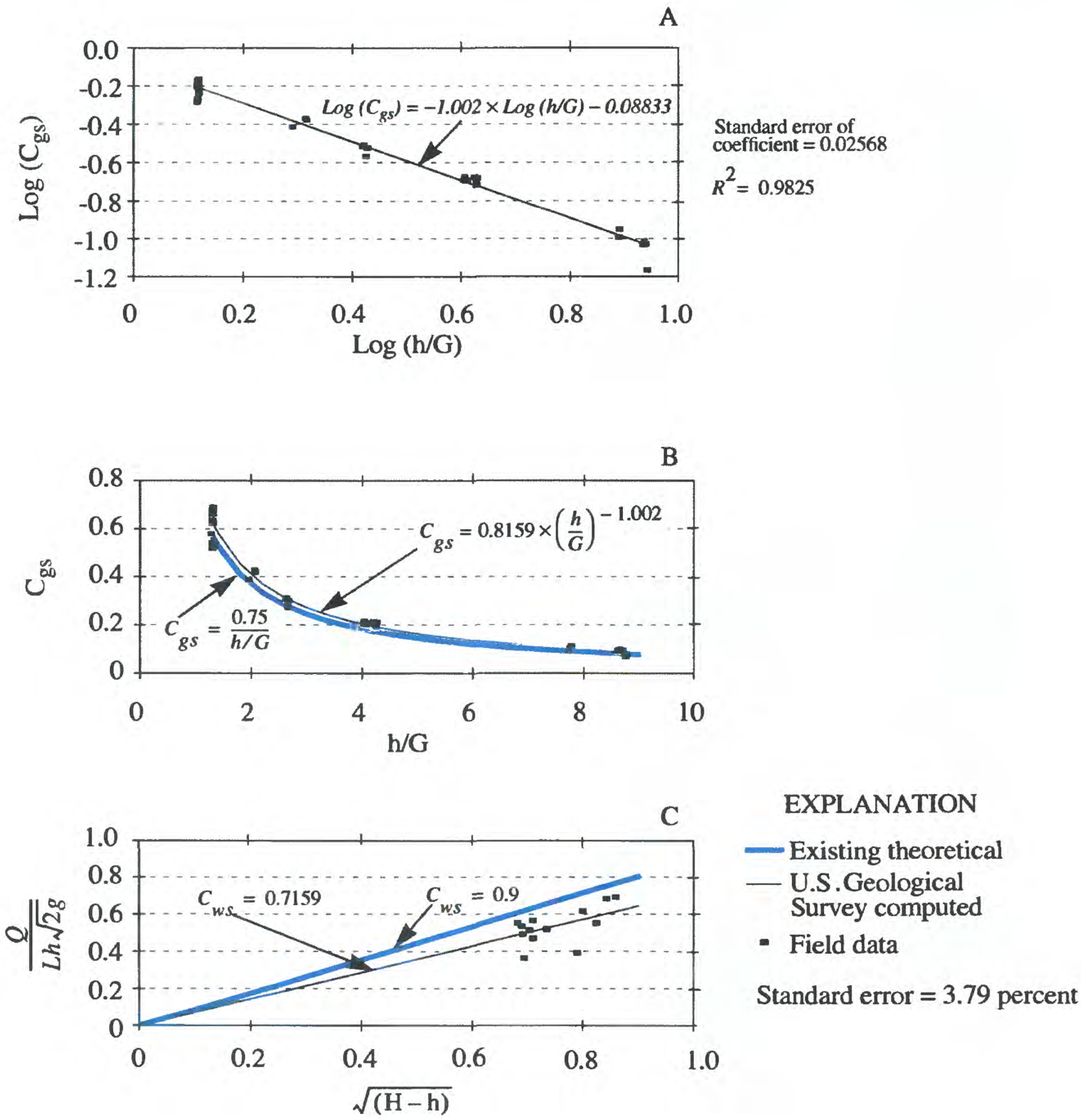

Figure 31. Logarithmic plot of the S-123 discharge coefficient for submerged orifice flow (graph A) and linear scale plots of a comparison of the S-123 discharge coefficient for submerged orifice flow (graph B) and submerged weir flow (graph C). An explanation of the mathematical symbols is given in appendix III. 
The flow through structure S-123 was computed for 1994 using both the theoretical- and computed-coefficient ratings as shown in figure 32 . The hydrograph comparison is very close because the ratings are very similar. The total flow for 1994 using the theoretical-coefficient rating is 22,405 acre-ft, and the total flow using the computed-coefficient rating is 24,404 acre-ft. The volumes differ by about 8.2 percent. Some negative flows were allowed at structure S-123.

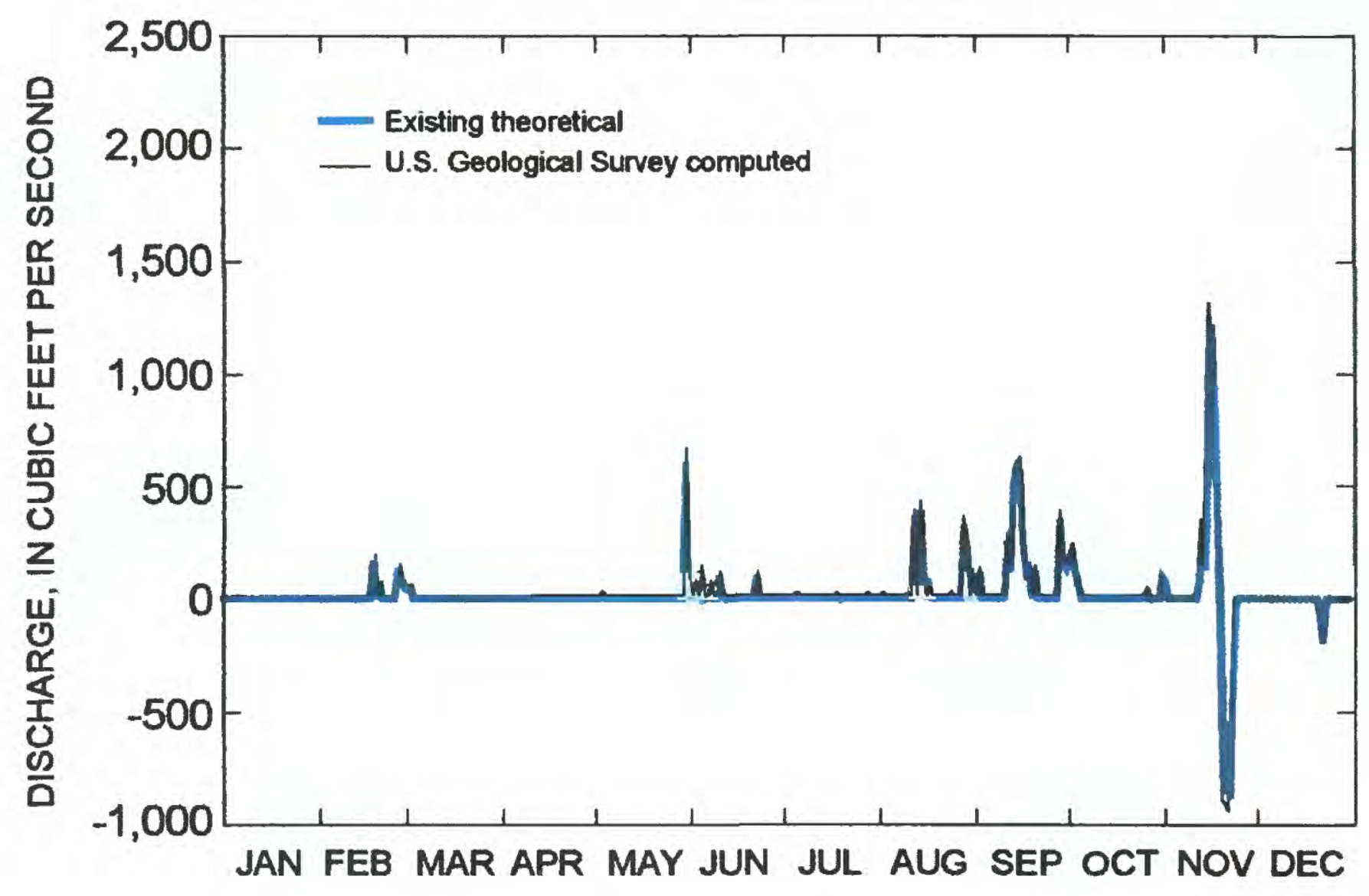

Figure 32. Theoretical and computed flows for structure S-123 in 1994. 


\section{Structure S-21}

Structure S-21 (fig. 33) is a reinforced-concrete gated spillway with discharge controlled by three cable-operated, vertical lift gates. This coastal structure is located in Miami near the mouth of the C-1 canal (Black Creek Canal) at its junction with the L-31E canal and is about 3,500 ft from Biscayne Bay (fig. 1). Structure S-21 maintains optimum water-control stages upstream in the C-1 canal and prevents saltwater intrusion during periods of high tide. Additionally, structure S-29 passes the design flood (40 percent of the SPF) without exceeding upstream flood design stage criteria set by water managers and restricting downstream flood stages and discharge velocities to nondamaging levels. The automatic controls on this coastal structure have an overriding mechanism that closes the gates, regardless of the upstream water level in the event of high tide, when the differential between the falling headwater and rising tailwater pool elevations reaches $0.2 \mathrm{ft}$. Appendix I presents flood discharge characteristics for structure S-21, and appendix II presents structural data for $\mathrm{S}-21$.
A substantial historical set of measurements exists for structure S-21. Twenty-one data points for submerged orifice flow were obtained from field measurements taken at structure S-21 between October 31, 1969, and September 22, 1987. In every instance but one, all three gates were opened at about the same height, with gate openings varying from 0.28 to $7.81 \mathrm{ft}$. On one occasion, two gates were opened at 0.73 and $0.75 \mathrm{ft}$ and the third gate remained closed. Seven measurements of submerged weir flow were taken at structure S-21 between August 17, 1988, and June 10, 1993, and on each occasion all three gates were opened. Field measurements for both submerged orifice and weir flows were taken using a Price current meter before the ADCP was in use by the USGS Miami Subdistrict office. Logarithmic and linear scale plots of the discharge-coefficient ratings for the submerged orificeand submerged weir-flow regimes are shown in figure 34 . The high values of the submerged weir coefficient probably reflect the upstream water-level gage being in the drawdown zone of weir flow.

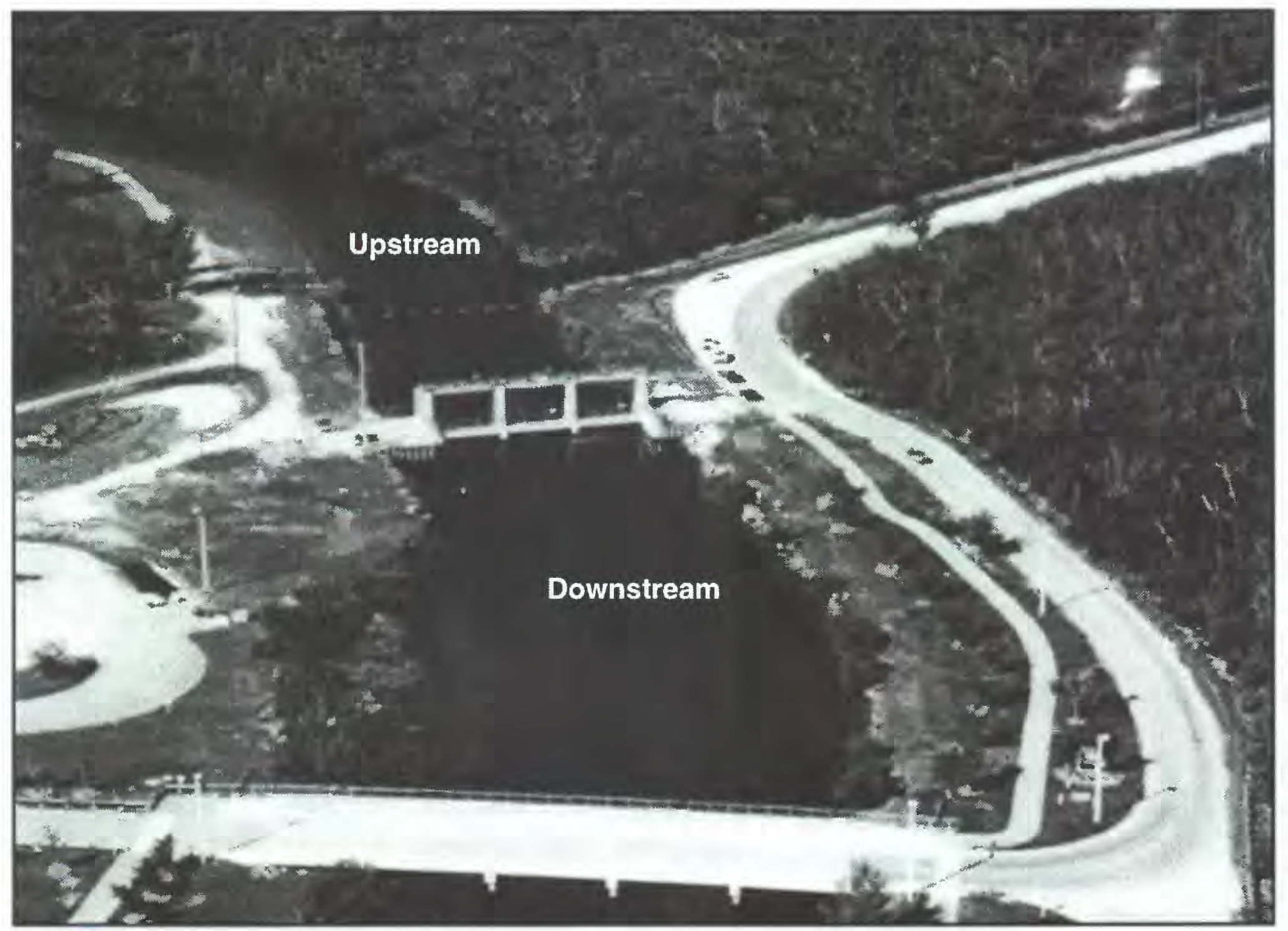

Figure 33. Structure S-21. 


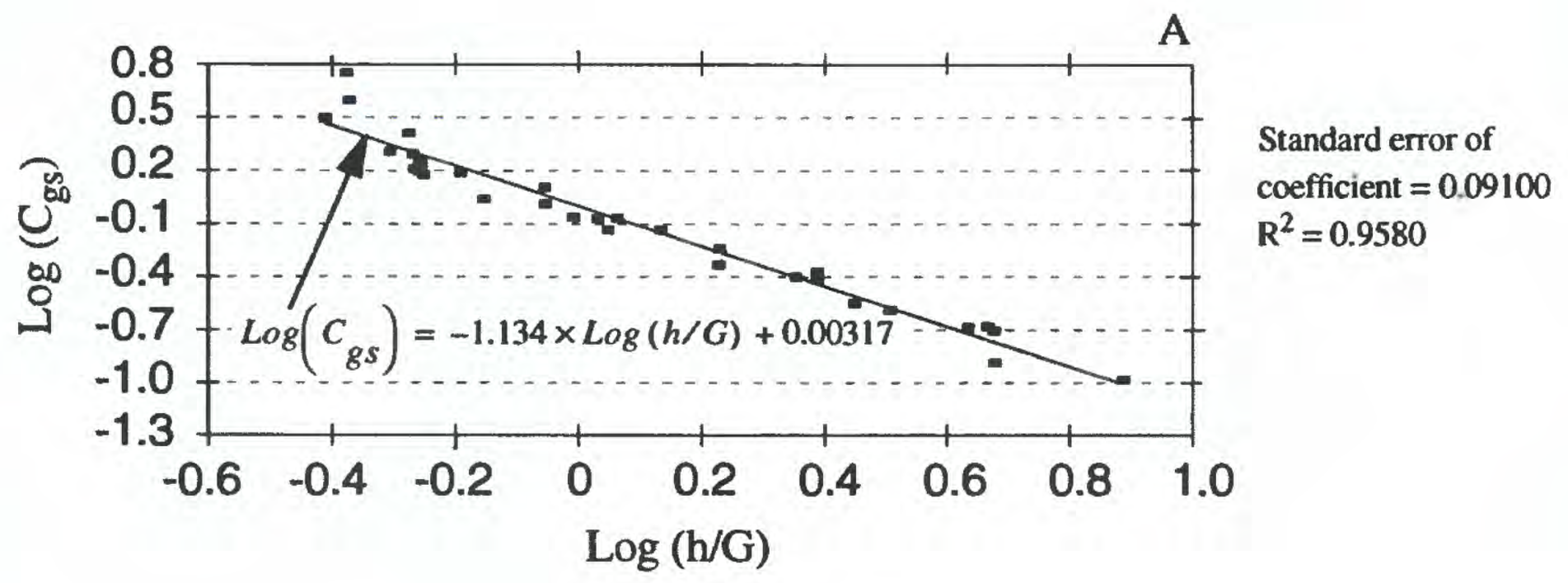

B
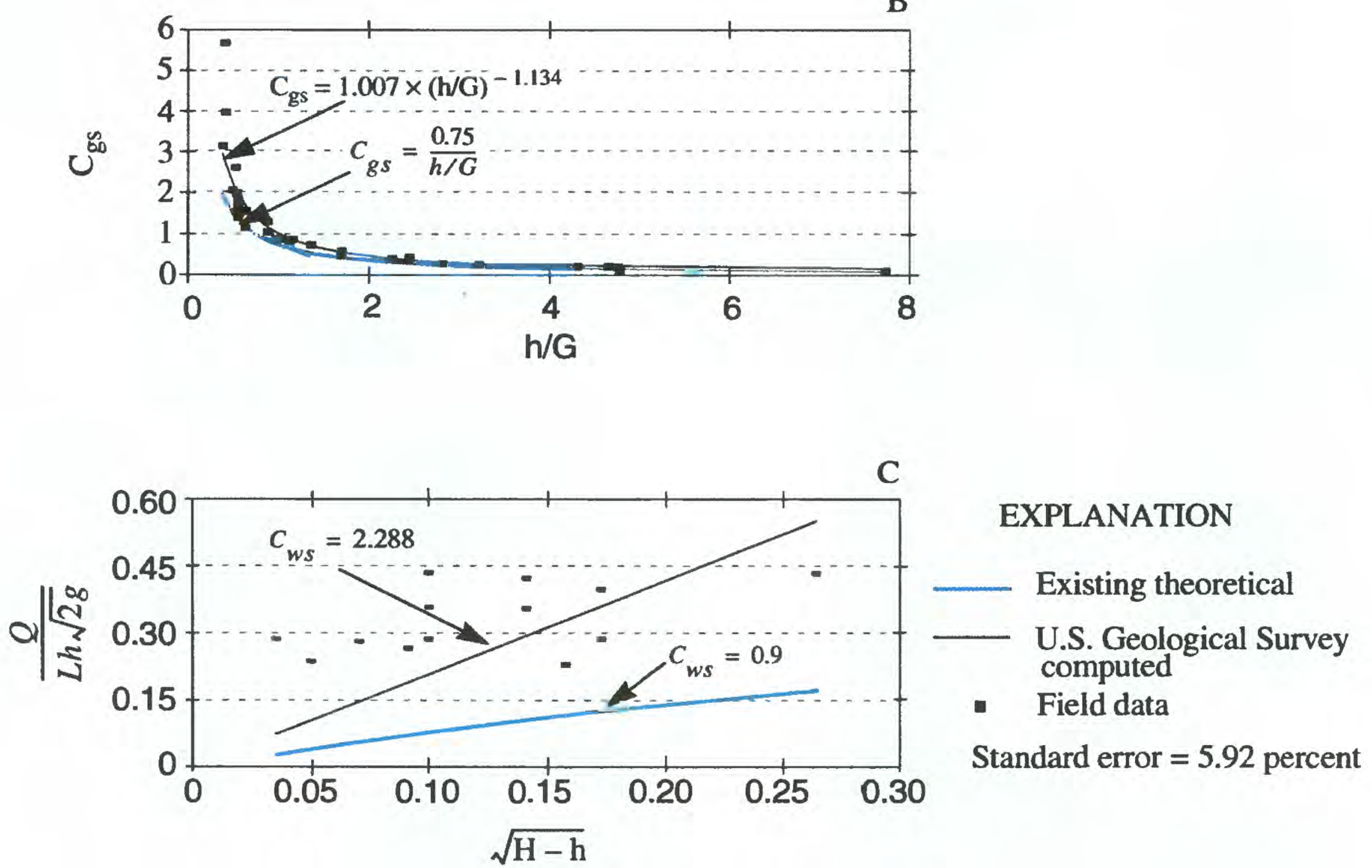

Figure 34. Logarithmic plot of the S-21 discharge coefficient for submerged orifice flow (graph A) and linear scale plots of a comparison of the S-21 discharge coefficient for submerged orifice flow (graph B) and submerged weir flow (graph C). An explanation of the mathematical symbols is given in appendix III. 
The flow through structure S-21 was computed for 1994 using both the theoretical- and computedcoefficient ratings as shown in figure 35 . Relatively large differences in the hydrograph comparison are seen at high weir flow, which is due to the rating differences seen in figure 34 . The total flow for 1994 using the theoretical-coefficient rating is 184,893 acre$\mathrm{ft}$, and the total flow using the computed-coefficient rating is 229,673 acre-ft. The volumes differ by about 19.5 percent.

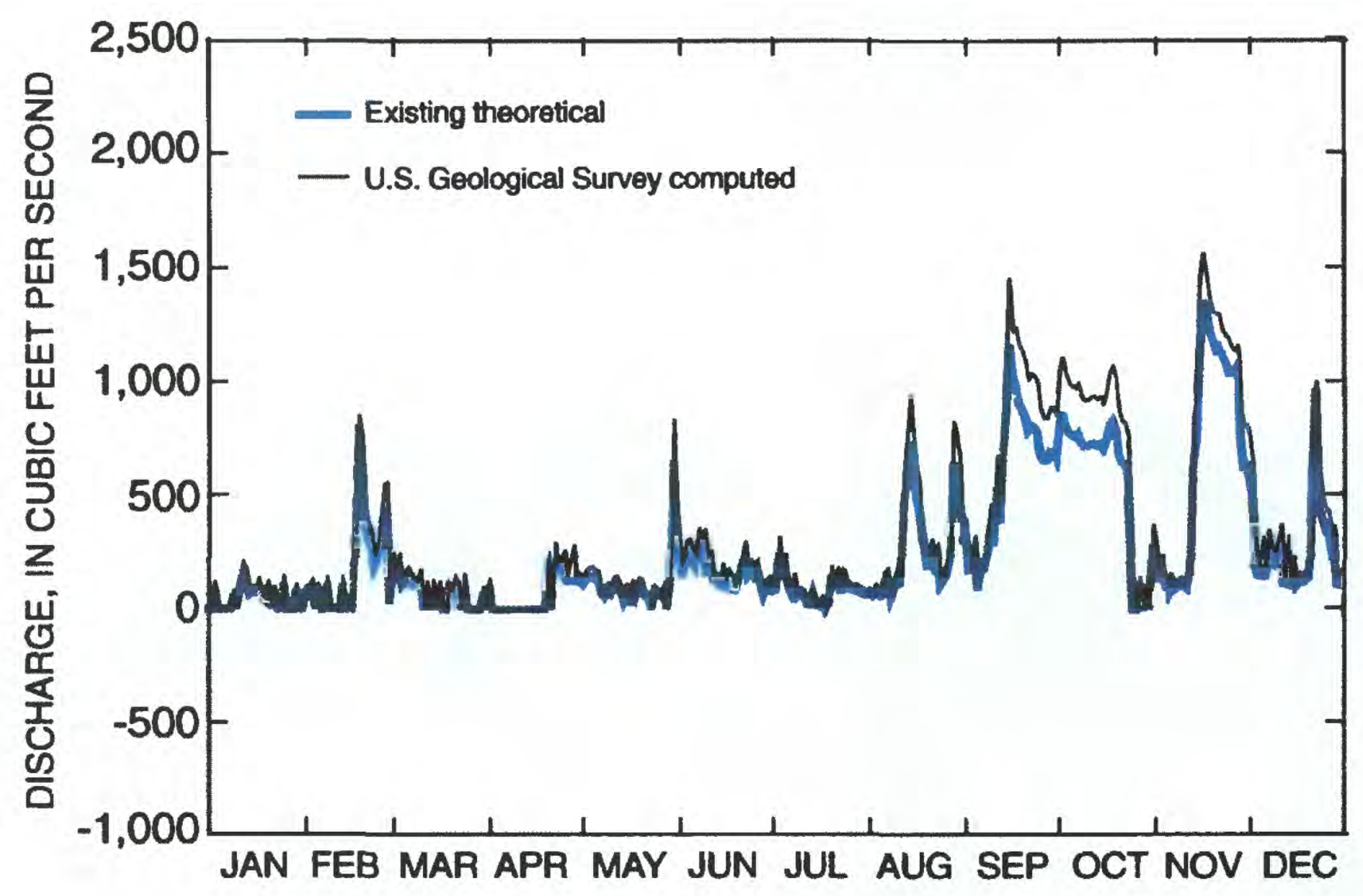

Figure 35. Theoretical and computed flows for structure S-21 in 1994. 


\section{Structure S-21A}

Structure S-21A (fig. 36) is a reinforced-concrete gated spillway with discharge controlled by two cableoperated, vertical lift gates. This coastal structure is located in Miami near the mouth of the C-102 canal (Princeton Canal) at its junction with the L-31E canal and is about $1 \mathrm{mi}$ from Biscayne Bay (fig. 1). Structure S-21A maintains optimum water-control stages upstream in the C-102 canal and prevents saltwater intrusion during periods of high tide. Additionally, structure S-21A passes the design flood (40 percent of the SPF) without exceeding upstream flood design stage criteria set by water managers and restricting downstream flood stages and discharge velocities to nondamaging levels. The automatic controls on this coastal structure have an overriding mechanism that closes the gates, regardless of the upstream water level in the event of high tide, when the differential between the falling headwater and rising tailwater pool elevations reaches $0.2 \mathrm{ft}$. Appendix I presents flood discharge characteristics for structure S-21A, and appendix II presents structural data for S-21A.

ADCP measurements were taken at structure S-21 A on March 23, 1995 (table 2), at the measurement section located immediately upstream of the structure (fig. 36). Data were collected for submerged orifice flow with two gates opened simultaneously at 1,2 , and $3 \mathrm{ft}$. Data were collected for submerged weir flow by opening one gate. Logarithmic and linear scale plots of the discharge-coefficient ratings for the submerged orifice- and submerged weir-flow regimes are shown in figure 37.

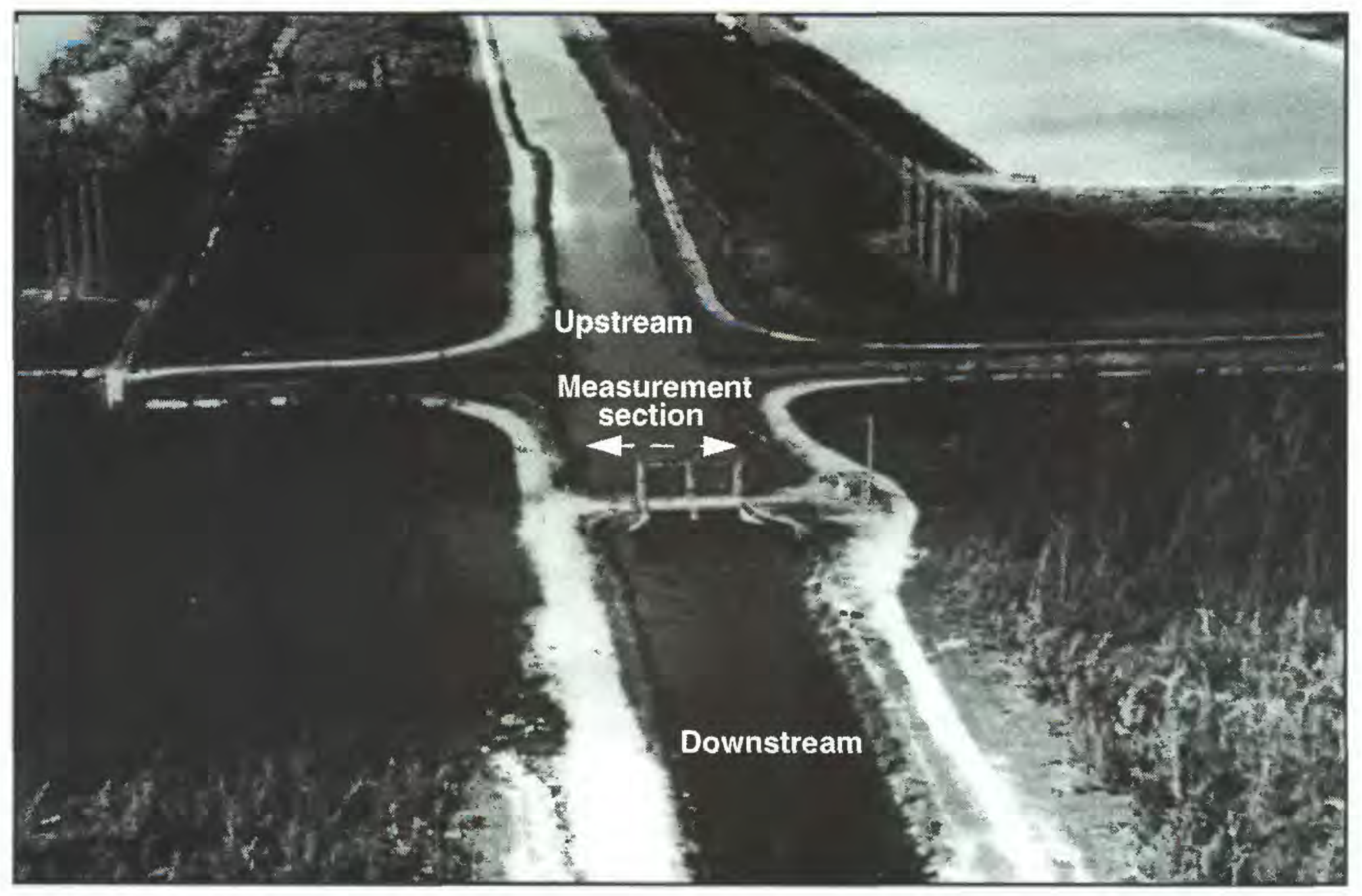

Figure 36. Structure S-21A. 

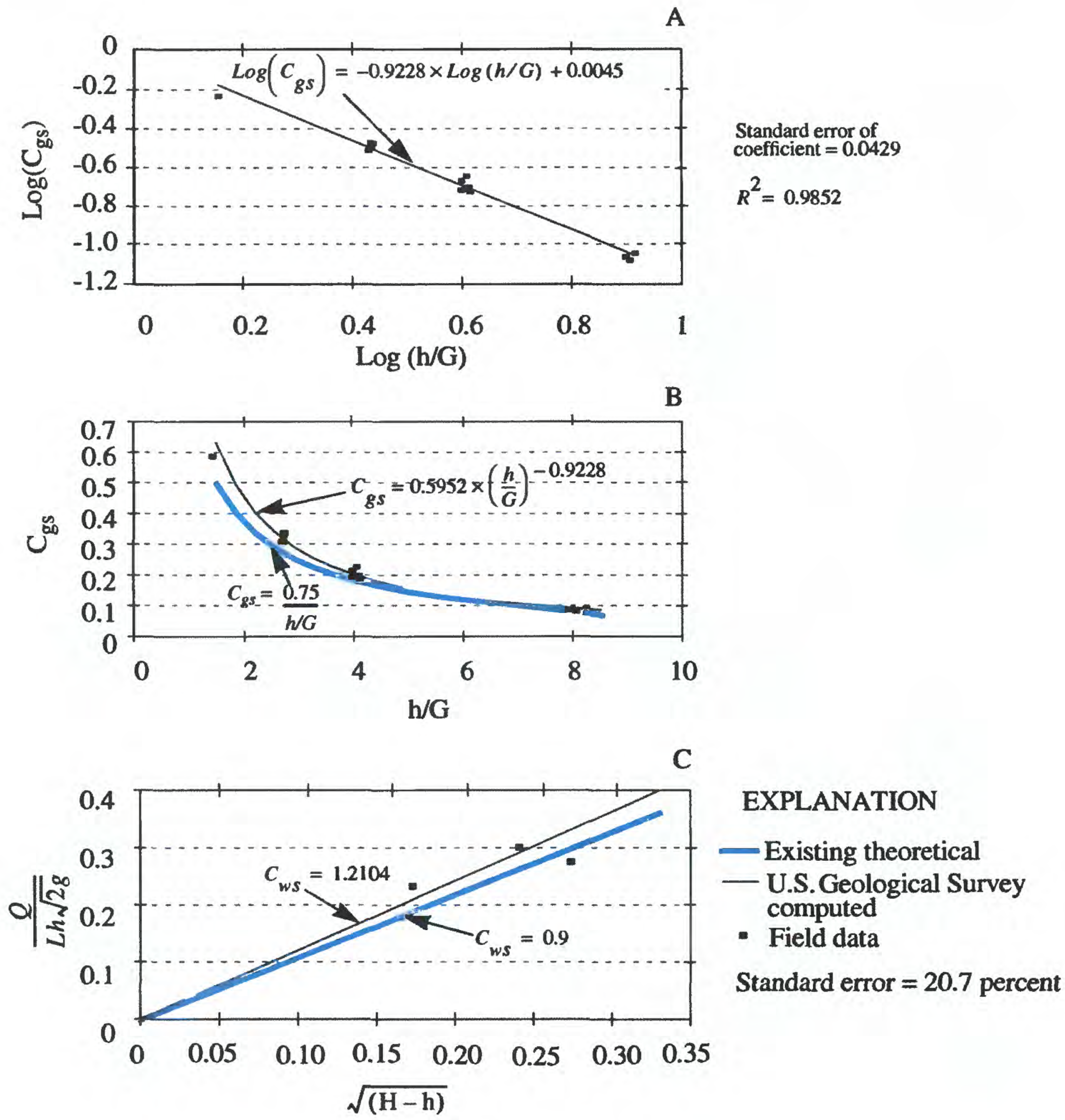

Figure 37. Logarithmic plot of the S-21A discharge coefficient for submerged orifice flow (graph A) and linear scale plots of a comparison of the S-21A discharge coefficient for submerged orifice flow (graph B) and submerged weir flow (graph C). An explanation of the mathematical symbols is given in appendix III. 
The flow through structure S-21A was computed for 1994 using both the theoretical- and computedcoefficient ratings as shown in figure 38 . It is interesting to note the high discharge period in November when the deviations between the two ratings occur. This result is due to a transition from weir flow (where the theoretical-coefficient rating determines higher flow) to orifice flow (where the computed-coefficient rating is higher). The total flow for 1994 using the theoreticalcoefficient rating is 93,467 acre-ft, and the total flow using the computed-coefficient rating is 103,147 acreft. The volumes differ by about 9.4 percent.

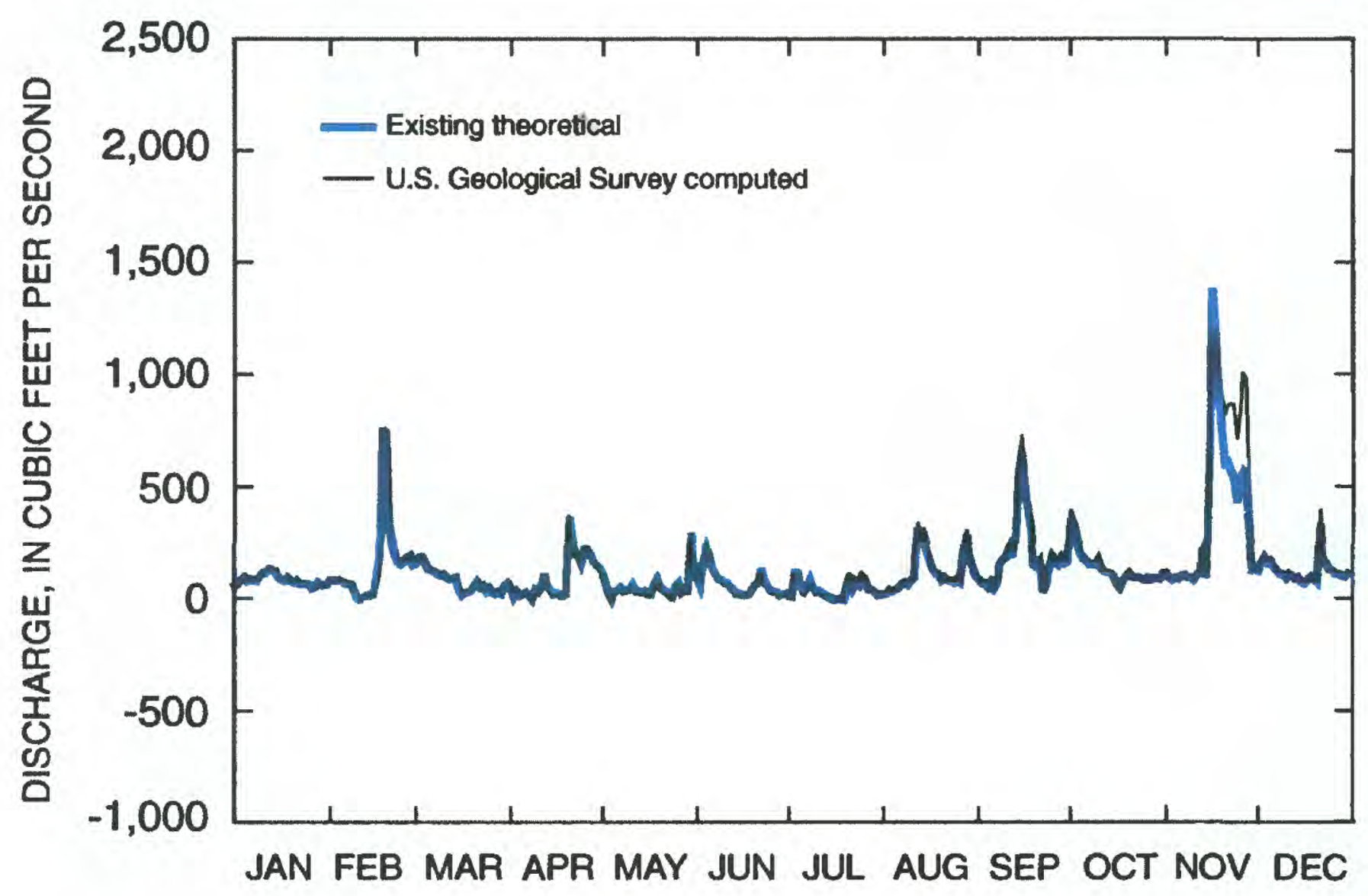

Figure 38. Theoretical and computed flows for structure S-21A in 1994. 


\section{Structure S-20G}

Structure S-20G (fig. 39) is a reinforced-concrete gated spillway with discharge controlled by a cableoperated, vertical lift gate. This coastal structure is located in Miami near the mouth of Military Canal at its junction with the L-31E canal (fig. 1). Structure S-20G maintains optimum water-control stages upstream in Military Canal and prevents saltwater intrusion during periods of high tide. Additionally, structure S-20G passes the design flood ( 40 percent of the SPF) without exceeding upstream flood design stage criteria set by water managers and restricting downstream flood stages and discharge velocities to nondamaging levels. The automatic controls on this coastal structure have an overriding mechanism that closes the gates, regardless of the upstream water level in the event of high tide, when the differential between the falling headwater and rising tailwater pool elevations reaches $0.2 \mathrm{ft}$. Appendix I presents flood discharge characteristics for structure S-20G, and appendix II presents structural data for S-20G.
ADCP measurements were taken at structure S-20G on March 21, 1995, March 22, 1995, and September 18, 1995 (table 2). The data collected from measurements taken on March 21, 1995, were not used because of the extremely low water velocities. On March 22, 1995, data were collected for submerged orifice and submerged weir flows at the measurement section closest to the coastal structure (fig. 39). The gate was opened at $2.5,3.0$, and $6.0 \mathrm{ft}$ to obtain data for submerged orifice flow and again was opened to obtain data for submerged weir flow. On September 18, 1995, two ADCP's were employed (one at each of the two measurement sections shown in fig. 39) to obtain data for both submerged orifice and submerged weir flows. The gate was opened at 1,2 , and $4 \mathrm{ft}$ to obtain data for submerged orifice flow and again was opened to obtain data for submerged weir flow. Logarithmic and linear scale plots of the discharge-coefficient ratings for the submerged orifice- and submerged weir-flow regimes are shown in figure 40 .

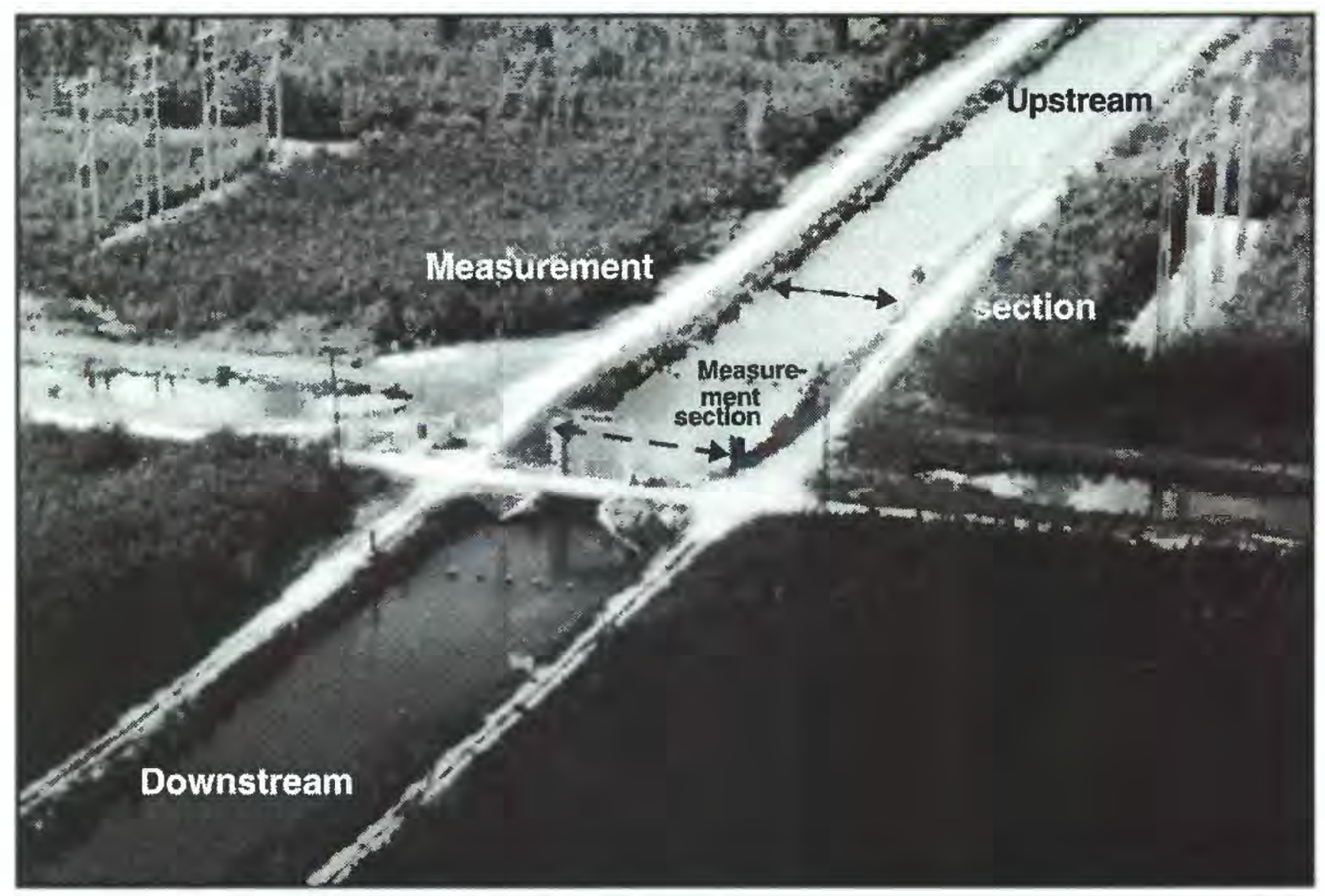

Figure 39. Structure S-20G. 

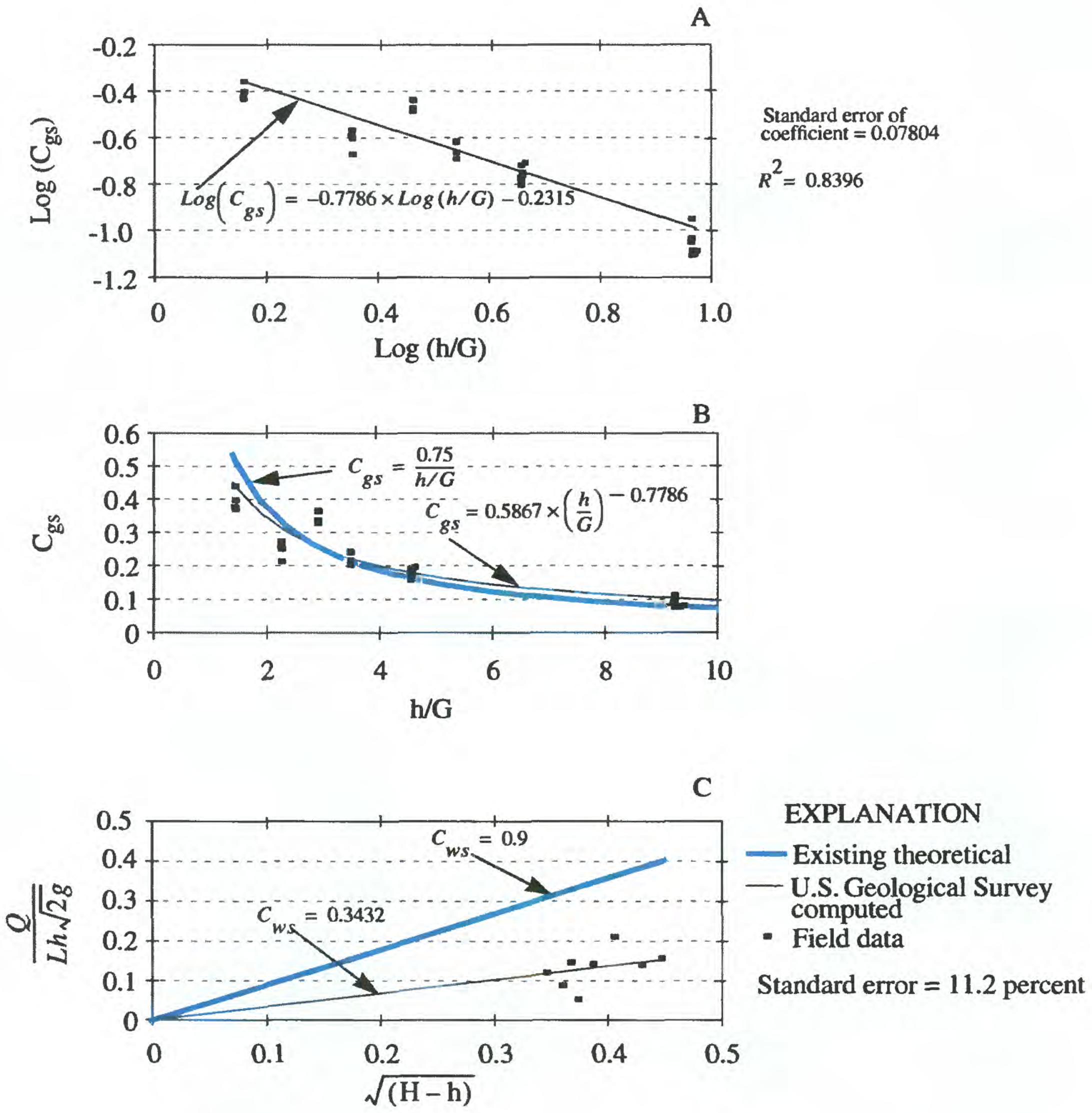

Figure 40. Logarithmic plot of the S-20G discharge coefficient for submerged orifice flow (graph A) and linear scale plots of a comparison of the S-20G discharge coefficient for submerged orifice flow (graph B) and submerged weir flow (graph C). An explanation of the mathematical symbols is given given in appendix III. 
The flow through structure S-20G was computed for 1994 using both the theoretical- and computed-coefficient ratings as shown in figure 41 . Low flows are seen at this coastal structure with insignificant differences in the hydrograph comparison. The total flow for 1994 using the theoretical-coefficient rating is 21,746 acre- $\mathrm{ft}$, and the total flow using the computed-coefficient rating is 22,003 acre-ft. The volumes differ by about 1.2 percent.

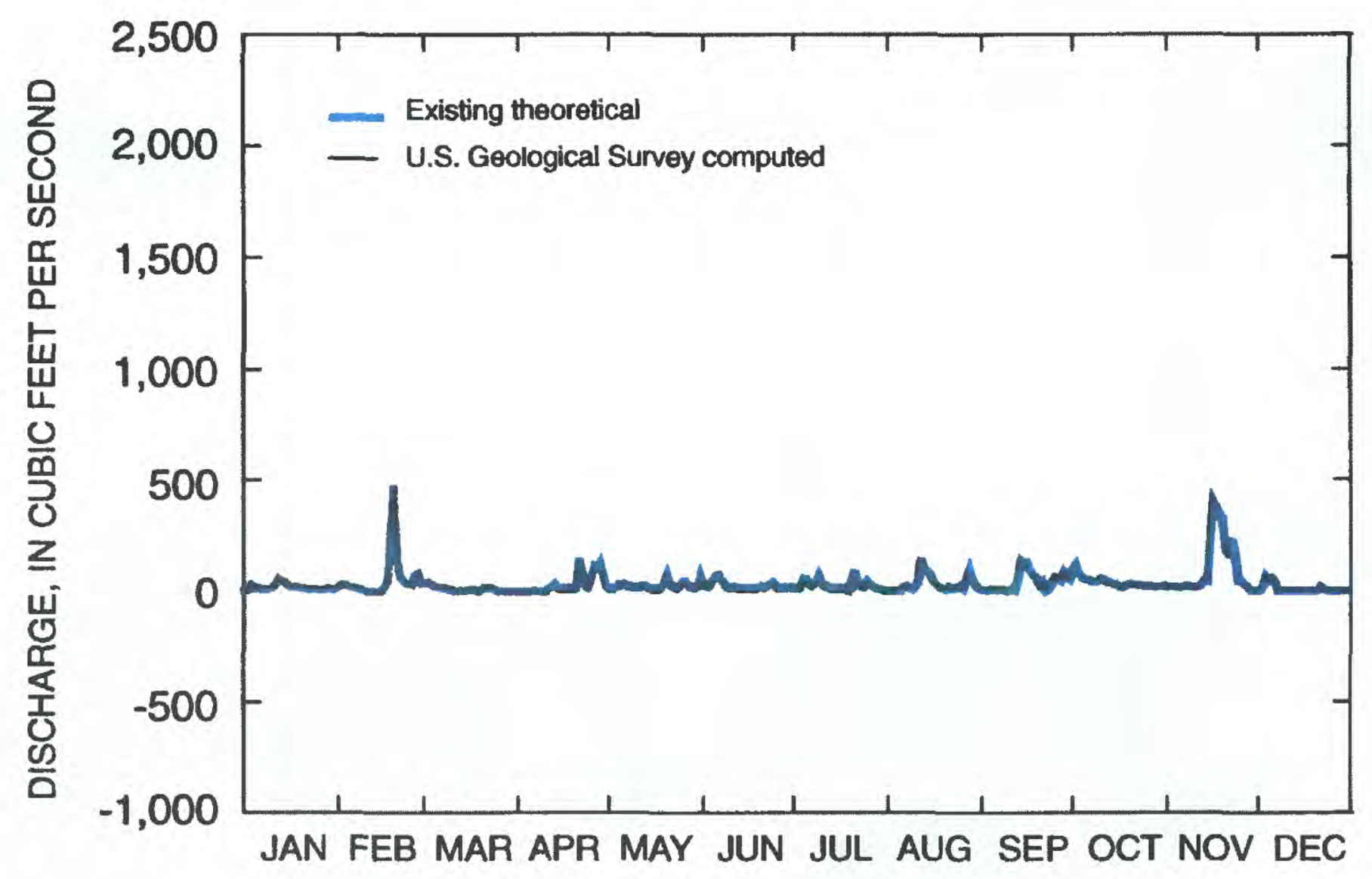

Figure 41. Theoretical and computed flows for structure S-20G in 1994. 


\section{Structure S-20F}

Structure S-20F (fig. 42) is a reinforced-concrete gated spillway with discharge controlled by three cable-operated, vertical lift gates. This coastal structure is located in Miami near the mouth of the C-103 canal (Mowry Canal) at its junction with the L-31E canal and is about 2,000 ft from Biscayne Bay (fig. 1). Structure S-20F maintains optimum water-control stages upstream in the C-103 canal and prevents saltwater intrusion during periods of high tide. Additionally, structure S-20F passes the design flood (40 percent of the SPF) without exceeding upstream flood design stage criteria set by water managers and restricting downstream flood stages and discharge velocities to nondamaging levels. The automatic controls on this coastal structure have an overriding mechanism that closes the gates, regardless of the upstream water level in the event of high tide, when the differential between the falling headwater and rising tailwater pool elevations reaches $0.3 \mathrm{ft}$. Appendix I presents flood discharge characteristics for structure S-20F, and appendix II presents structural data for S-20F.

Measurements were taken at structure S-20F on June 19, 1995 (table 2), at the two measurement sections shown in figure 42. Two ADCP's were used to measure flow-one in the L-31E canal and the other in the $\mathrm{C}-103$ canal. Both measurements were taken simultaneously, and together represented the total flow entering structure S-20F. One gate was opened at 1, 2, 4, 6, and $8 \mathrm{ft}$ to obtain data for submerged orifice flow, and the same gate was opened to obtain data for submerged weir flow. The other two gates remained closed for all measurements. Logarithmic and linear scale plots of the discharge-coefficient ratings for the submerged orifice- and submerged weir-flow regimes are shown in figure 43.

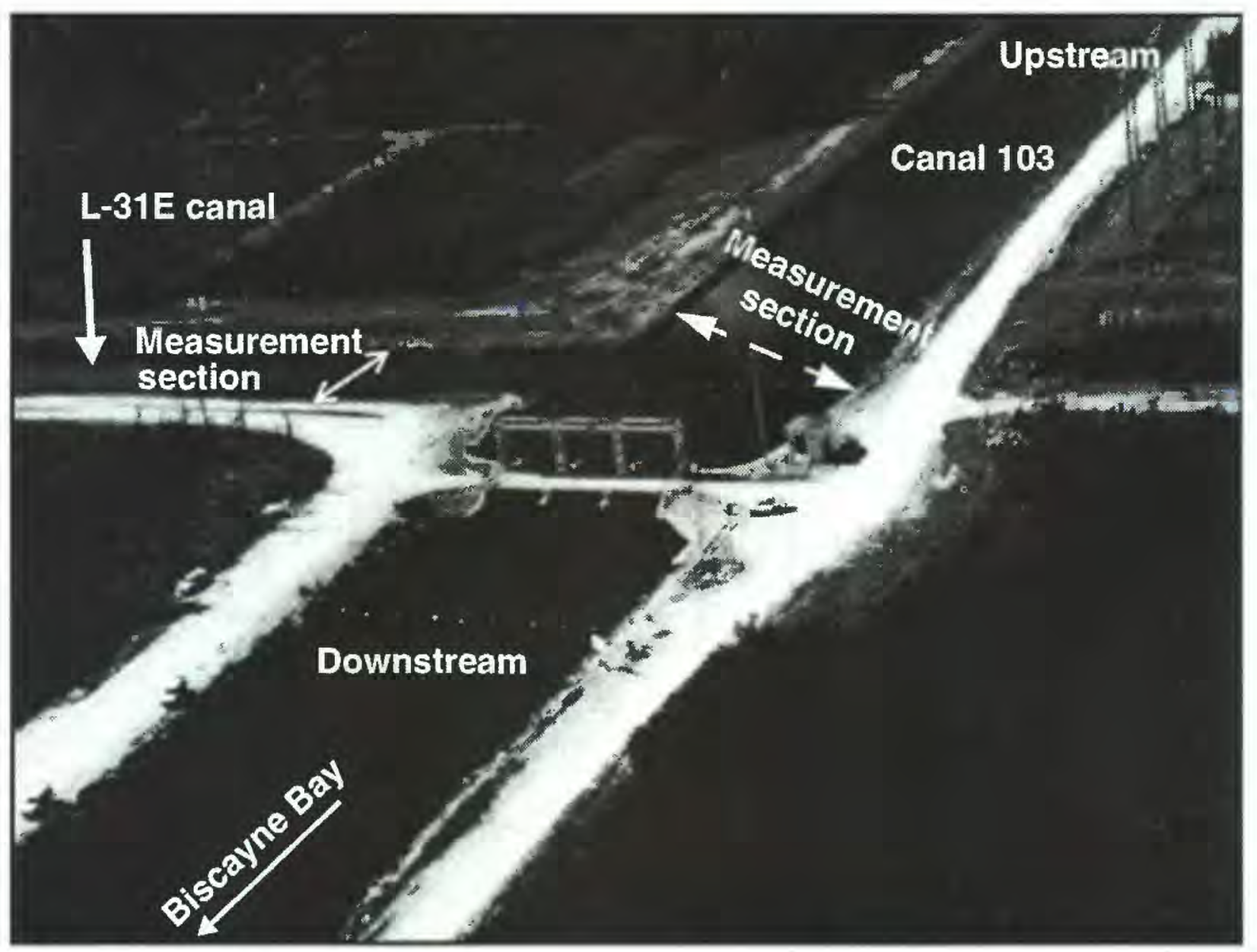

Figure 42. Structure S-20F. 
A
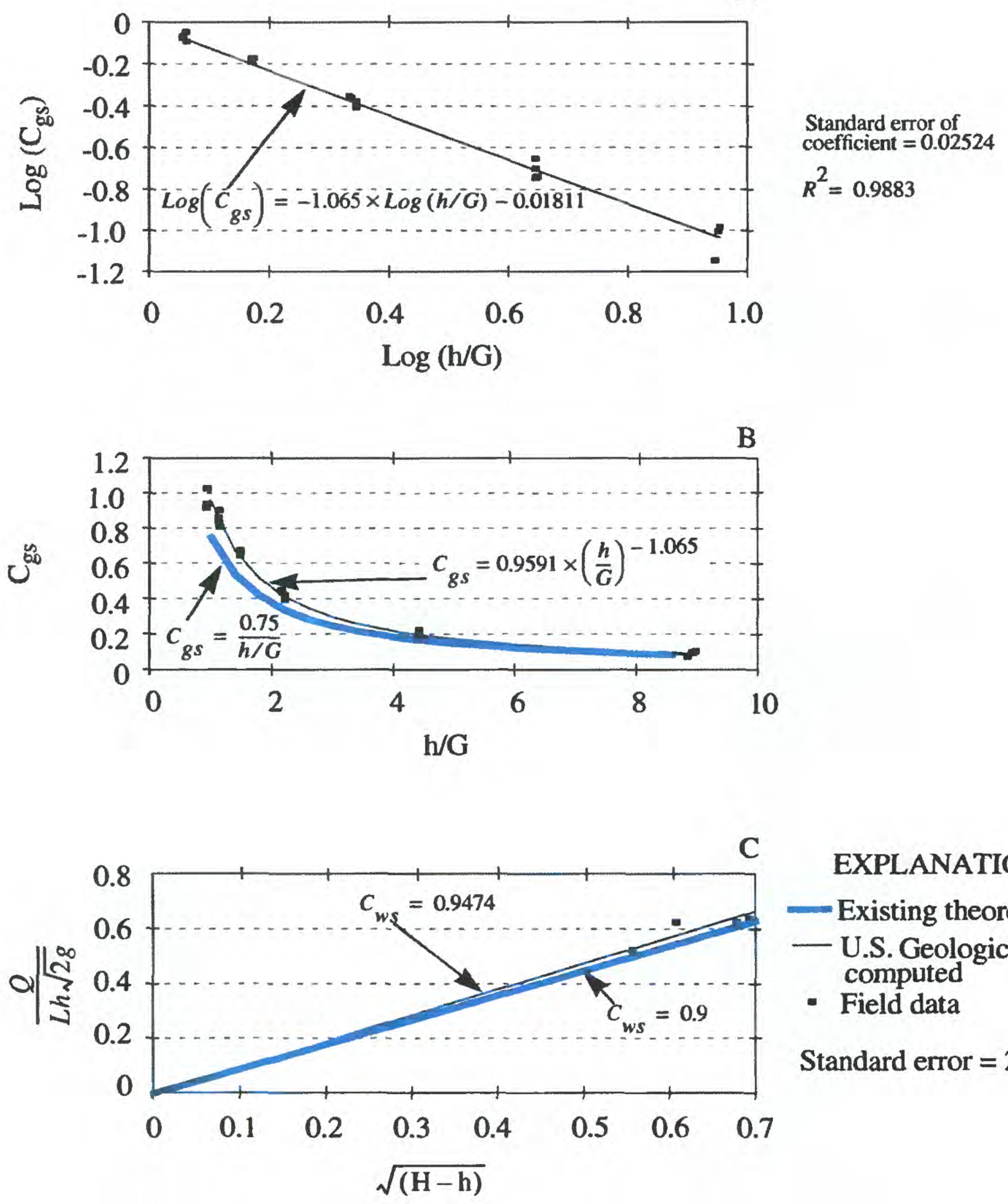

EXPLANATION

- Existing theoretical

- U.S. Geological Survey computed

- Field data

Standard error $=2.67$ percent

Figure 43. Logarithmic plot of the S-20F discharge coefficient for submerged orifice flow (graph A) and linear scale plots of a comparison of the S-2OF discharge coefficient for submerged orifice flow (graph B) and submerged weir flow (graph C). An explanation of the mathematical symbols is given in appendix III. 
The flow through structure S-20F was computed for 1994 using both the theoretical- and computed-coefficient ratings as shown in figure 44 .

There are significant differences in flow with the computed-coefficient rating determining higher discharges. The total flow for 1994 using the theoretical-coefficient rating is $172,588 \mathrm{acre}-\mathrm{ft}$, and the total flow using the computed-coefficient rating is 220,212 acre-ft. The volumes differ by about 21.6 percent.

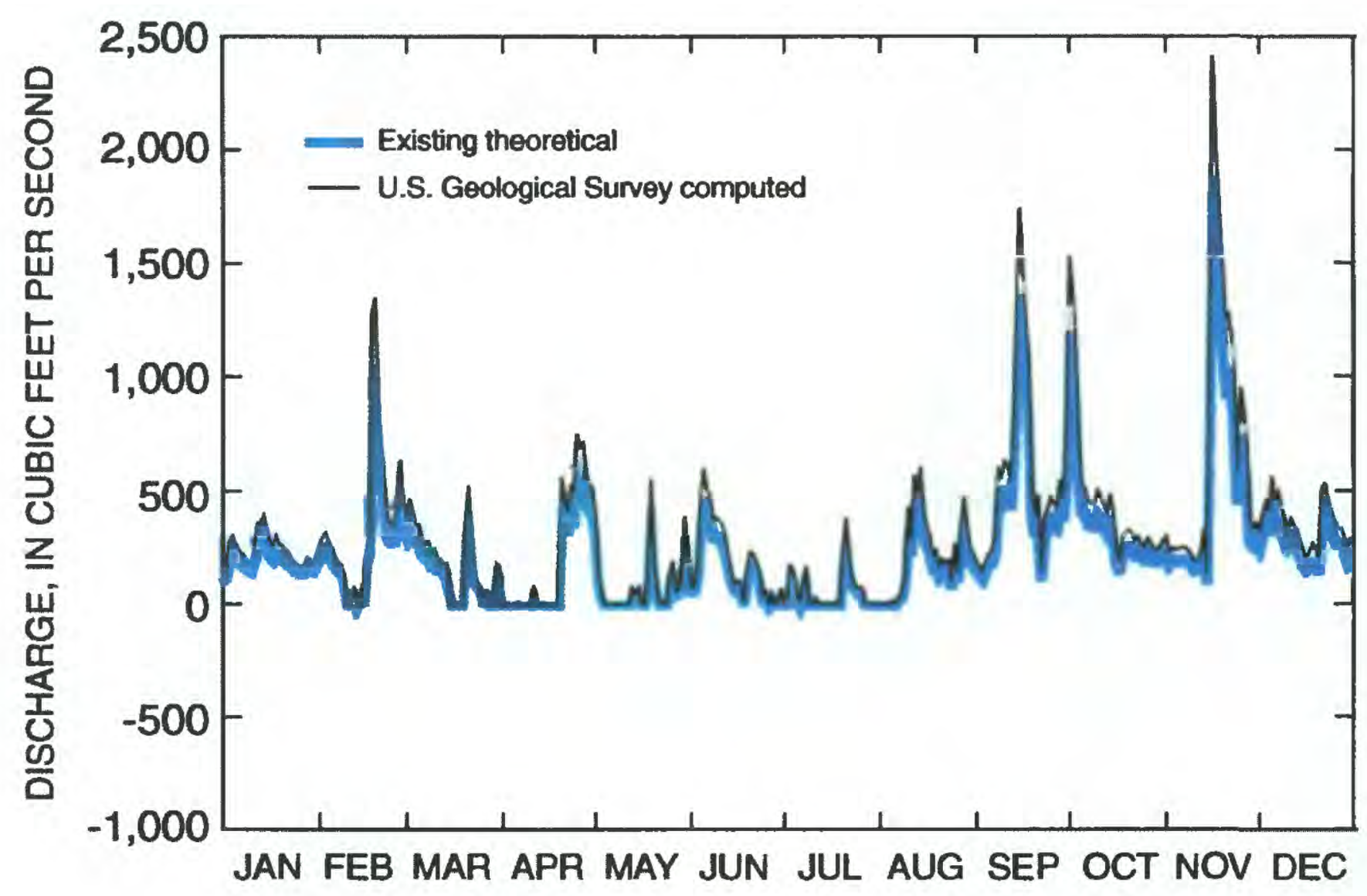

Figure 44. Theoretical and computed flows for structure S-20F in 1994. 


\section{Structure S-20}

Structure S-20 (fig. 45) is a reinforced-concrete gated spillway with discharge controlled by a cableoperated, vertical lift roller gate. This coastal structure is located in Miami on the C-107 canal and is about 3 mi from Biscayne Bay (fig. 1). Structure S-20 maintains optimum water-control stages upstream in the C-107 canal and prevents saltwater intrusion during periods of high tide. Additionally, structure S-20 passes the design flood ( 40 percent of the SPF) without exceeding upstream flood design stage criteria set by water managers and restricting downstream flood stages and discharge velocities to nondamaging levels. The automatic controls on this coastal structure have an overriding mechanism that closes the gates, regardless of the upstream water level in the event of high tide, when the differential between the falling headwater and rising tailwater pool elevations reaches $0.3 \mathrm{ft}$. Appendix I presents flood discharge characteristics for structure S-20, and appendix II presents structural data for S-20.

ADCP measurements were taken at structure S-20 on March 20, 1995, June 21, 1995, and September 19,1995 (table 2), at the two measurement sections shown in figure 45. One ADCP was used to take measurements on March 20, 1995, and two ADCP's were used to take measurements on June 21, 1995, and September 19, 1995. On March 20, 1995, the gate was opened at $1,2,3,4$, and $6 \mathrm{ft}$ and lifted from the water to obtain measurements. On June 21, 1995, the gate was opened at 1 and $2 \mathrm{ft}$ to obtain data for submerged orifice flow. On September 19, 1995, the gate was opened at 2,4 , and $6 \mathrm{ft}$ to obtain data for submerged orifice flow and again was opened to obtain data for submerged weir flow. Logarithmic and linear scale plots of the discharge-coefficient ratings for the submerged orifice- and submerged weir-flow regimes are shown in figure 46.

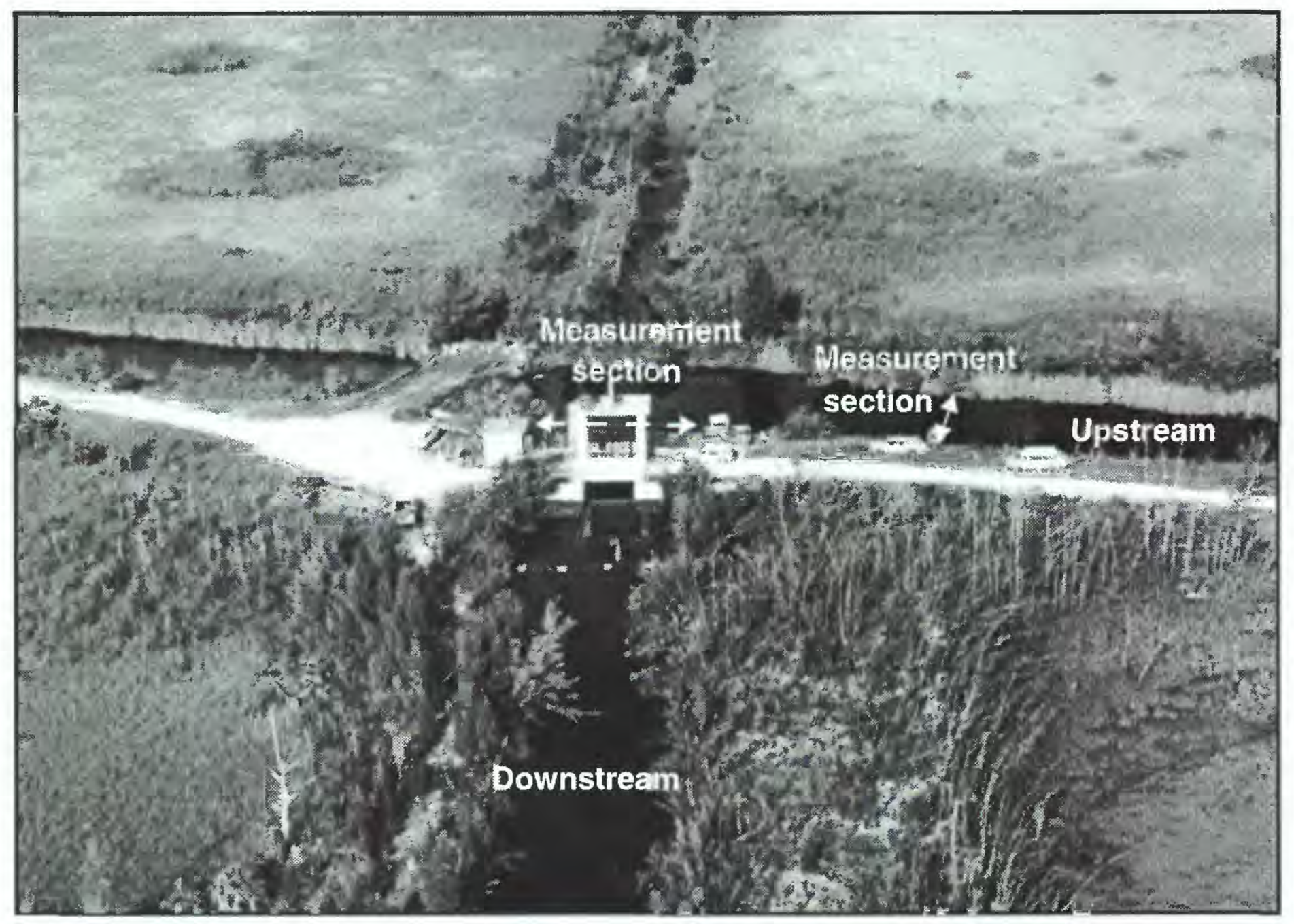

Figure 45. Structure S-20. 


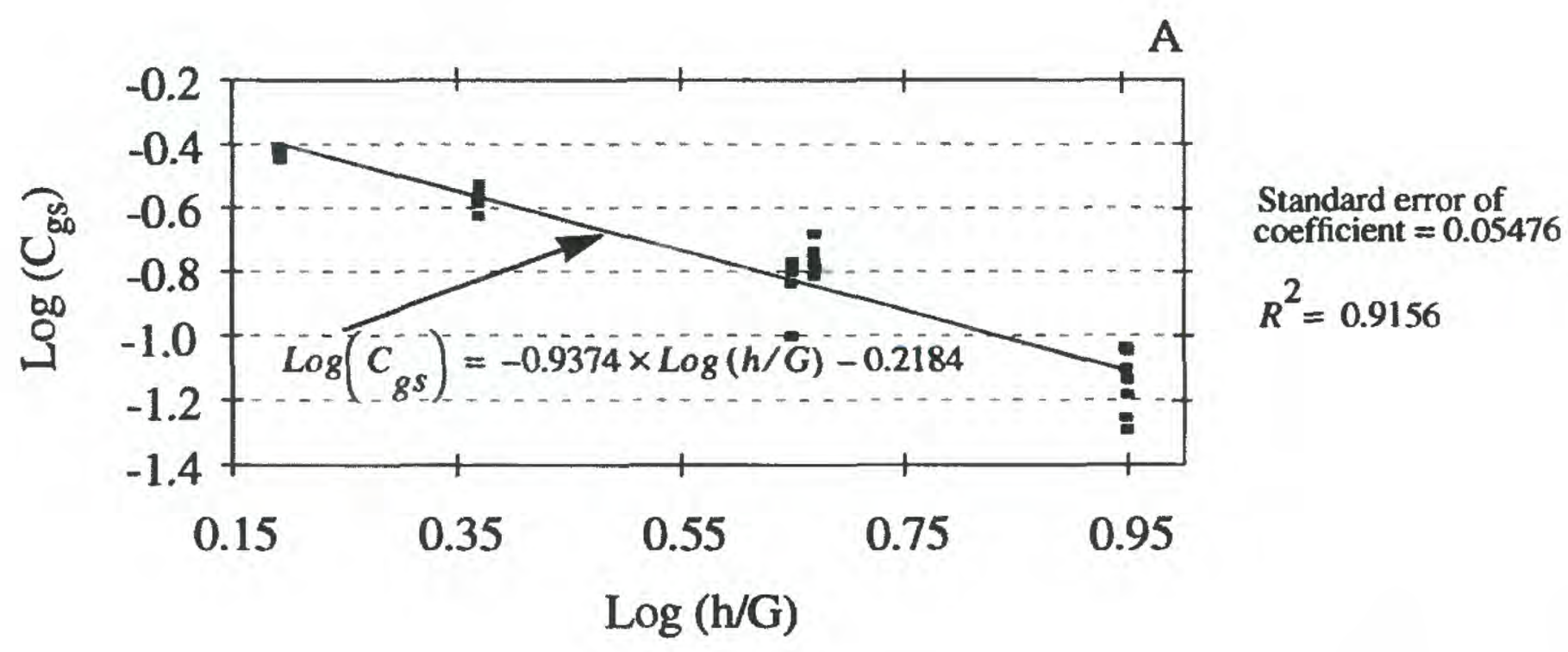

B

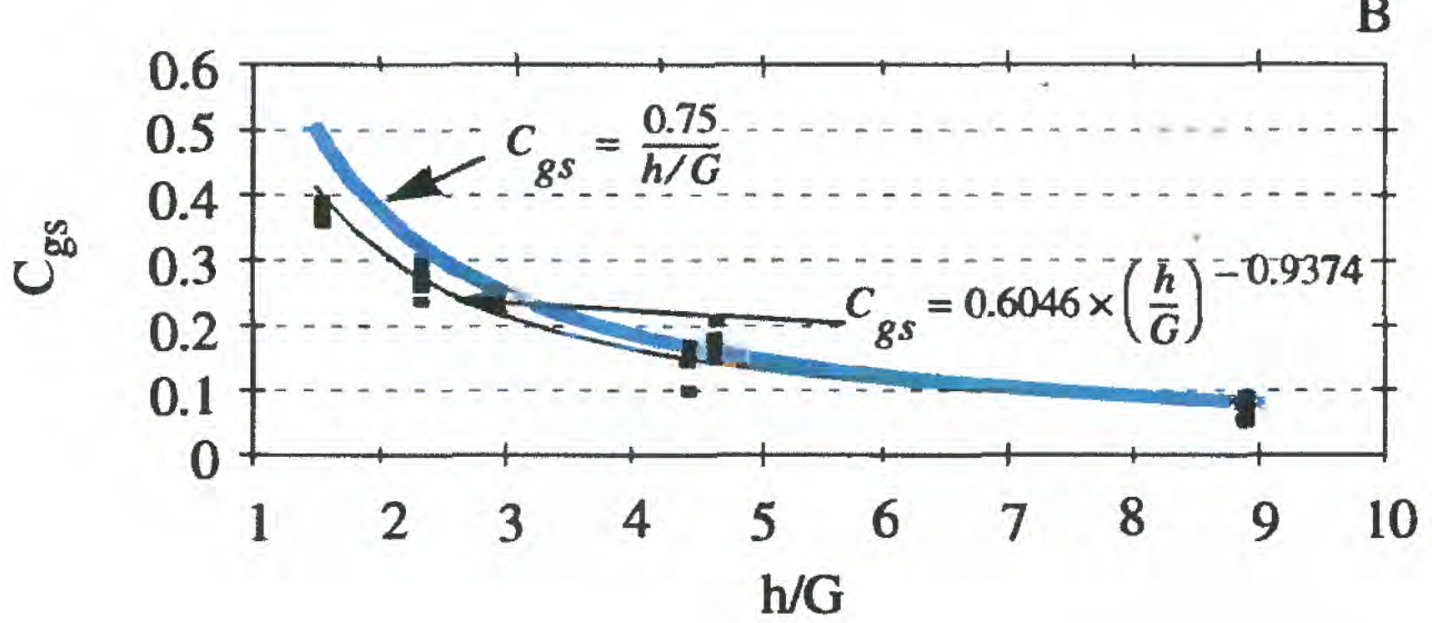

C

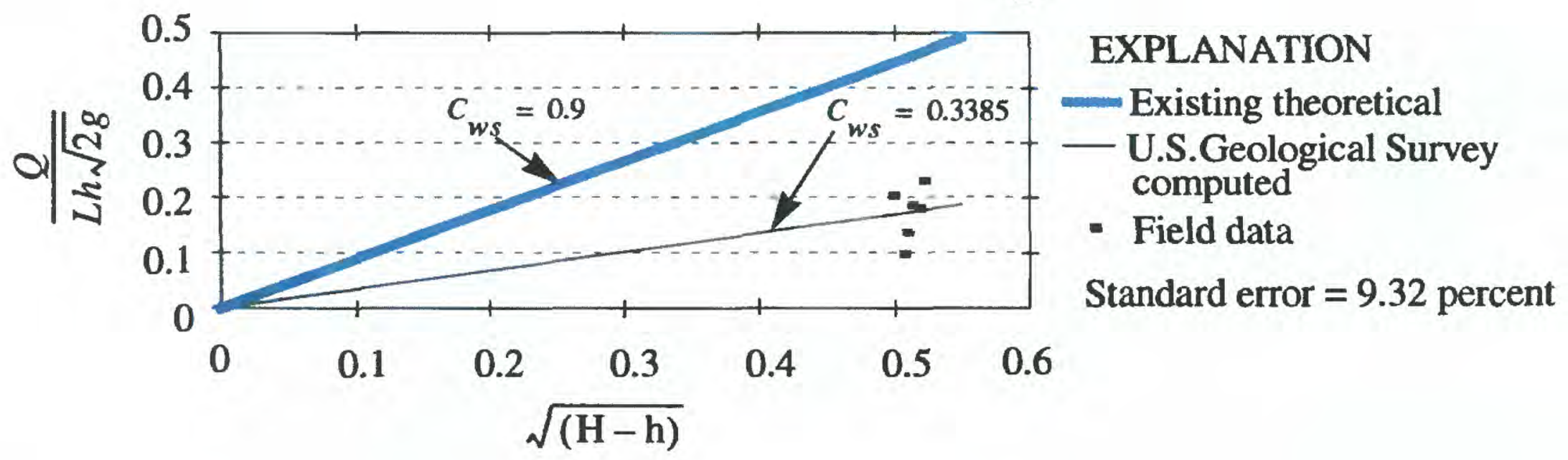

Figure 46. Logarithmic plot of the S-20 discharge coefficient for submerged orifice flow (graph A) and linear scale plots of a comparison of the S-20 discharge coefficient for submerged orifice flow (graph B) and submerged weir flow (graph C). An explanation of the mathematical symbols is given in appendix III. 
The flow through structure S-20 was computed for 1994 using both the theoretical -and computed-coefficient ratings as shown in figure 47. Data were missing for January, February, and part of March; however, only 4 months (September-December) experienced flow, which happened to be relatively small compared to the other coastal structures. The total flow for 1994 using the theoretical-coefficient rating is 20,983 acre- $\mathrm{ft}$, and the total flow using the computed-coefficient rating is 19,533 acre-ft. The volumes differ by about 7.4 percent.

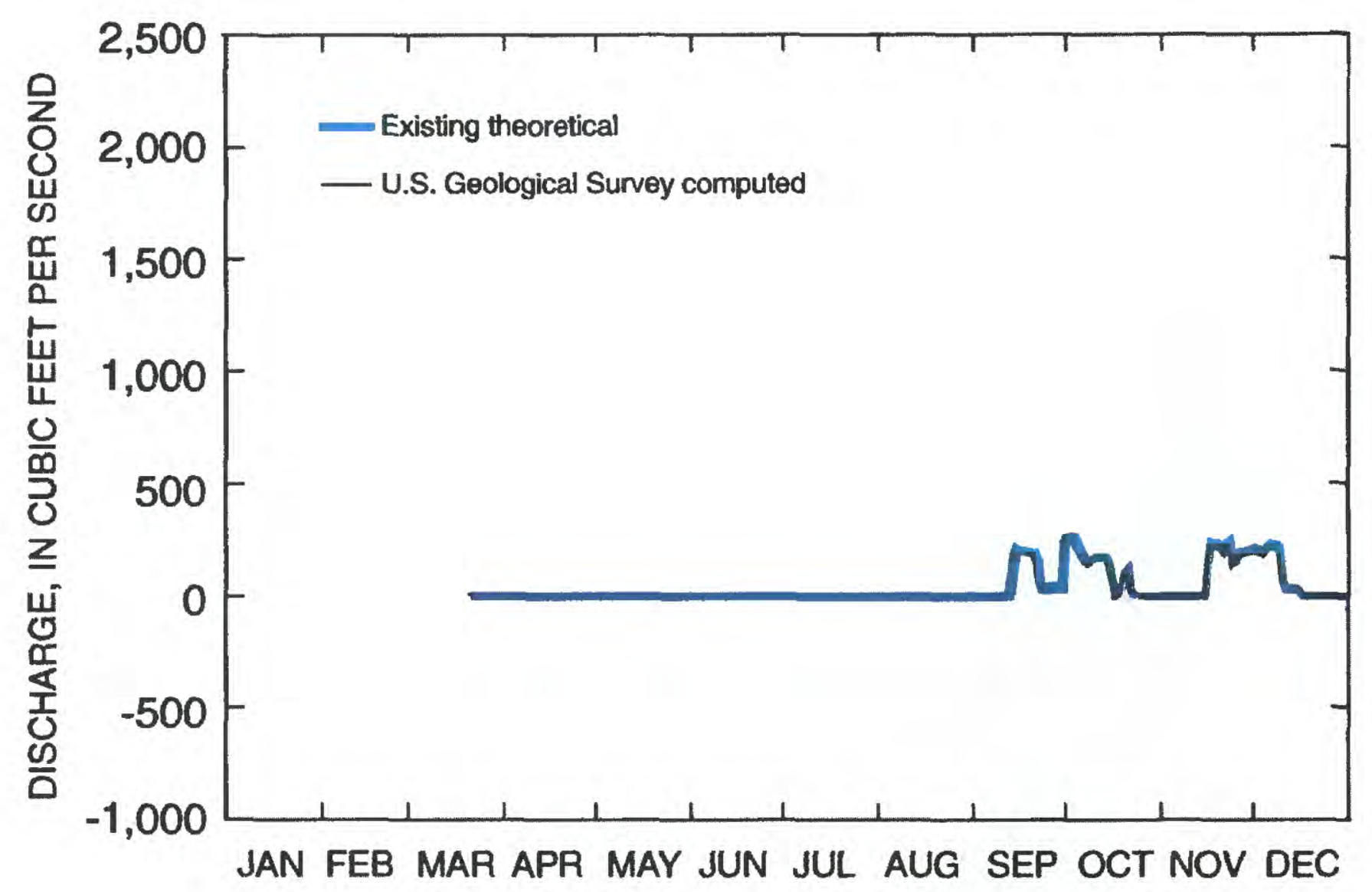

Figure 47. Theoretical and computed flows for structure S-20 in 1994. 


\section{Structure S-197}

Structure S-197 (fig. 48) is a 13-barrel, corrugated-metal-pipe culvert located in Miami near the mouth of the C-111 canal and is about $3 \mathrm{mi}$ from Manatee Bay and $750 \mathrm{ft}$ east of U.S. Highway 1 (fig. 1). This nontelemetric coastal structure maintains optimum water-control stages upstream in the $\mathrm{C}-111$ canal and prevents saltwater intrusion during periods of high tide. Additionally, structure S-197 diverts discharge from an upstream noncoastal structure overland to the panhandle of Everglades National Park and releases water only during major floods. Appendix I presents flood discharge characteristics for structure S-197, and appendix II presents structural data for S-197.

ADCP measurements were taken at structure S-197 on November 18, 1994, June 23, 1995, October 19, 1995, and October 24, 1995 (table 2), at the measurement section shown in figure 48. The November 1994, June 1995, and October 1995 measurements were taken with 13,12 , and 7 gates opened, respectively. The discharge-coefficient rating is given as a liner scale plot in figure 49. The distinct data clusters are due to the method by which structure S-197 is operated. The gates are completely opened or shut.

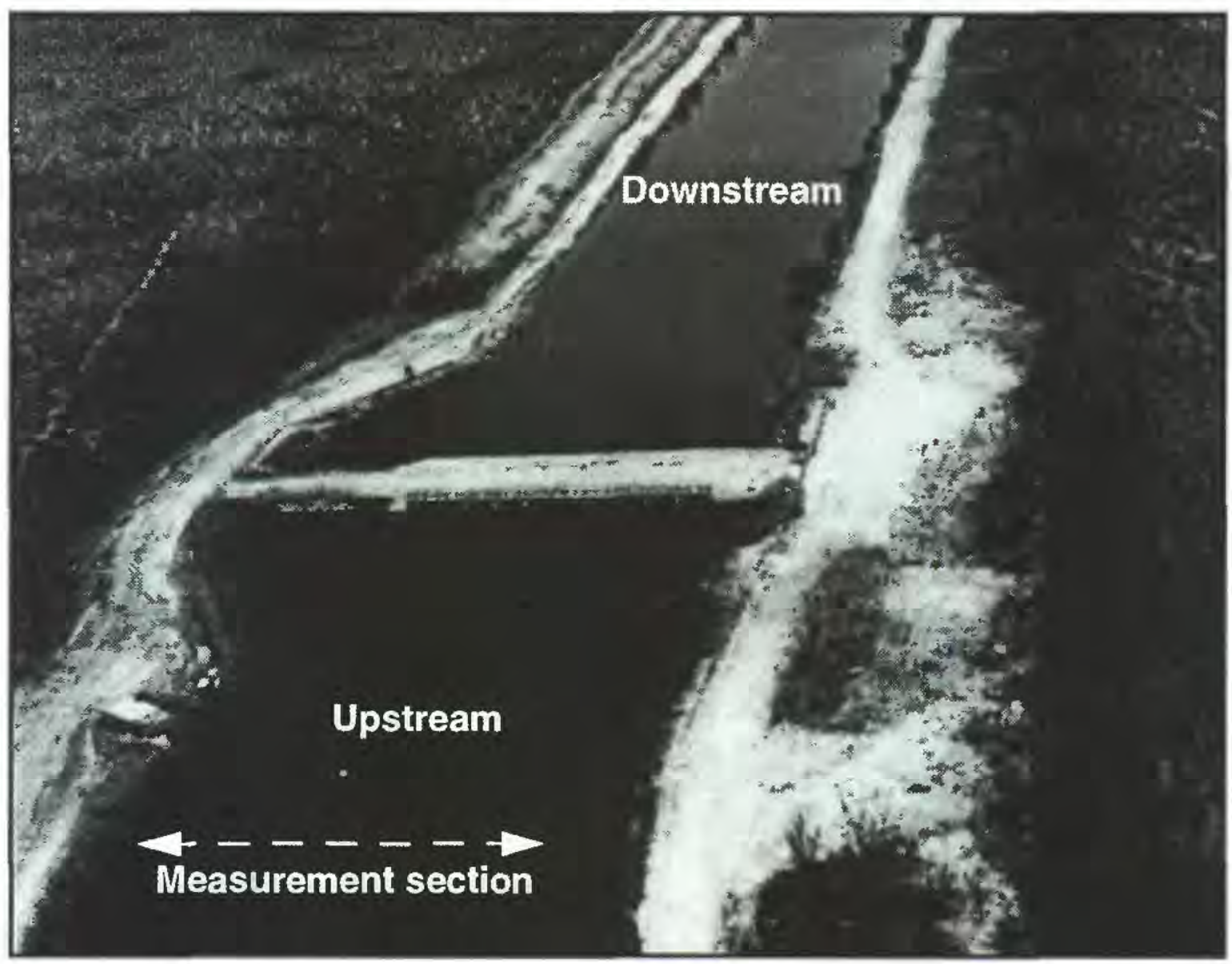

Figure 48. Structure S-197. 


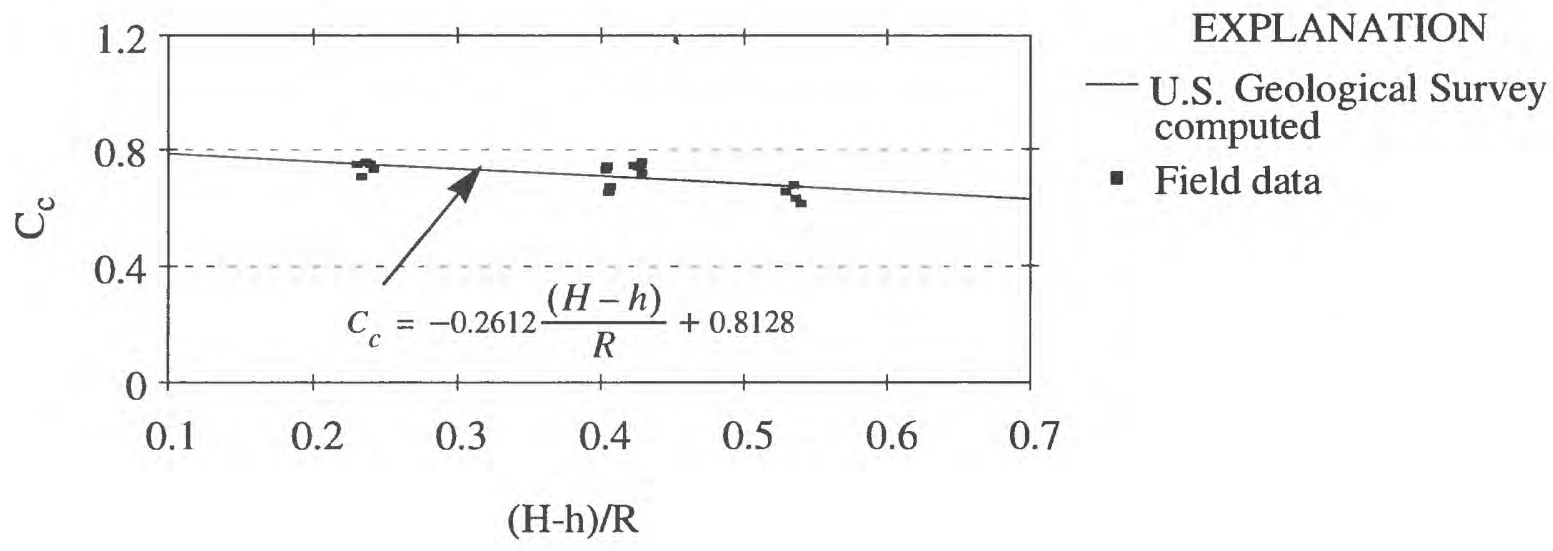

Figure 49. Linear scale plot of the discharge coefficient for the S-197 gated culvert. An explanation of the mathematical symbols is given in appendix III.

\section{SUMMARY AND EVALUATION OF DISCHARGE-COEFFICIENT RATINGS}

The difference between the theoretical- and computed-coefficient ratings varied from structure to structure. The theoretical- and computed-coefficient ratings for submerged orifice flow were within 10 percent at structures S-22, S-25B, S-26, S-27, S-28, and S-123; however, marked differences (25 percent or greater) were seen at structures S-20F and S-21. The theoretical- and computed-coefficient ratings for submerged weir flow were within 10 percent at structures G-93, S-20F, S-27, S-29, and S-123; however, marked differences (25 percent or greater) were seen at structures S-20, S-20G, S-21, S-21A, S-25B, and S-28. The closest match to the theoretical-coefficient rating was at structure $S-123$, and the worst match to the theoretical-coefficient rating was at structure S-21. The significant differences between the theoretical- and computed-coefficient ratings could be a result of basing the ratings on 30 or fewer data points.

There are many factors that could affect the accuracy of a theoretical flow coefficient applied to a coastal structure even if it was calibrated by laboratory tests and SFWMD field calibrations. The application of a theoretical flow coefficient assumes that the coastal structure is a complete control section in the channel. The resistance of the coastal structure is the only limiting factor in the discharge. However, at a real coastal structure, this is not entirely correct. The upstream and downstream channel conditions might affect the discharge. The effective flow area through the coastal structure opening might not be what is assumed in the theoretical flow coefficient.

It is significant that some of the submerged weir flow measurements were taken at high submergence ratios $(h / H>0.99)$. This, of course, causes errors in stage measurement to be more significant, meaning at very high submergence ratios, it is difficult to accurately determine a value of $C_{w s}$. From the equation, error in $Q$ is proportional to the square root of $H / h$ error.

The transformation from a simple linear logregression gives a rating curve based on the medians (not the means), and therefore, the result might be biased low. One way to correct for this bias is by using a nonparametric or "smearing" estimate of mass, which only requires the assumption that the residuals are independent and homeostatic. This equation, shown below, was produced by Helsel and Hirsch (1992) for a log transform and can be generalized for any transform:

$$
Y_{i}=\frac{\sum_{i=1} f^{-1}\left(b_{0}+b_{1} X_{i}+e_{i}\right)}{n},
$$

where $Y_{i}$ is the response variable; $f^{-1}$ is the inverse of the selected transformation; constants $b_{0}$ and $b_{l}$ are the coefficients of the fitted regression; $e_{i}$ represents the residuals, $Y_{i}=b_{0}+b_{1} X_{i}+e_{i}$, where $X_{i}$ is the specific value of $X$ for which we want to estimate $Y$; and $n$ is Manning's frictional factor. 
The smearing estimator is based on each of the residuals being equally alike and "smears" their magnitudes in the original units across the range of $X$, which in this instance, is $\log h / G$. This is accomplished by reexpressing the residuals, $e_{i}$, from the log-log equation into the original units and computing their mean. This mean is the "bias-correction factor" to be multiplied by the median estimate for all $X_{o}$.

This analysis was conducted on 24 orifice-flow measurements for structure S-21 in southern Dade County. A regression analysis was performed to provide coefficients $b_{o}, Y$-intercept, and $b_{I}$ (slope) for a best fit line. The residual, $e_{i}$, difference between the log of the data point and the log of the best fit was calculated for each of the 24 orifice-flow measurements. The smearing estimator, $Y_{i}$, was then computed for each measurement using each of the $\log h / G$ values. The best fit was used as the $Y_{i}$ set and compared with the adjusted $Y_{i}$ set, the average $Y_{i}$ for a given $\log h / G$. $Y_{i}$ was then plotted against the percent error. The average difference is 2.72 percent, and the largest difference is 3.77 percent. The bias was within 1 to 4 percent, and therefore, justifies the original fit.

The flow hydrographs for each coastal structure presented in this report show the effects of the differences in the theoretical- and computed-coefficient ratings on flows. The total volume of freshwater flow to tidewater is significant to water managers because it affects the freshwater available for human consumption and also the ecology of Biscayne Bay. This volume constitutes the majority of the flow directly into Biscayne Bay. Figure 50 shows the 1994 cumulative flow volumes for 12 of the 16 coastal structures under theoretical- and computed-coefficient ratings. Negative

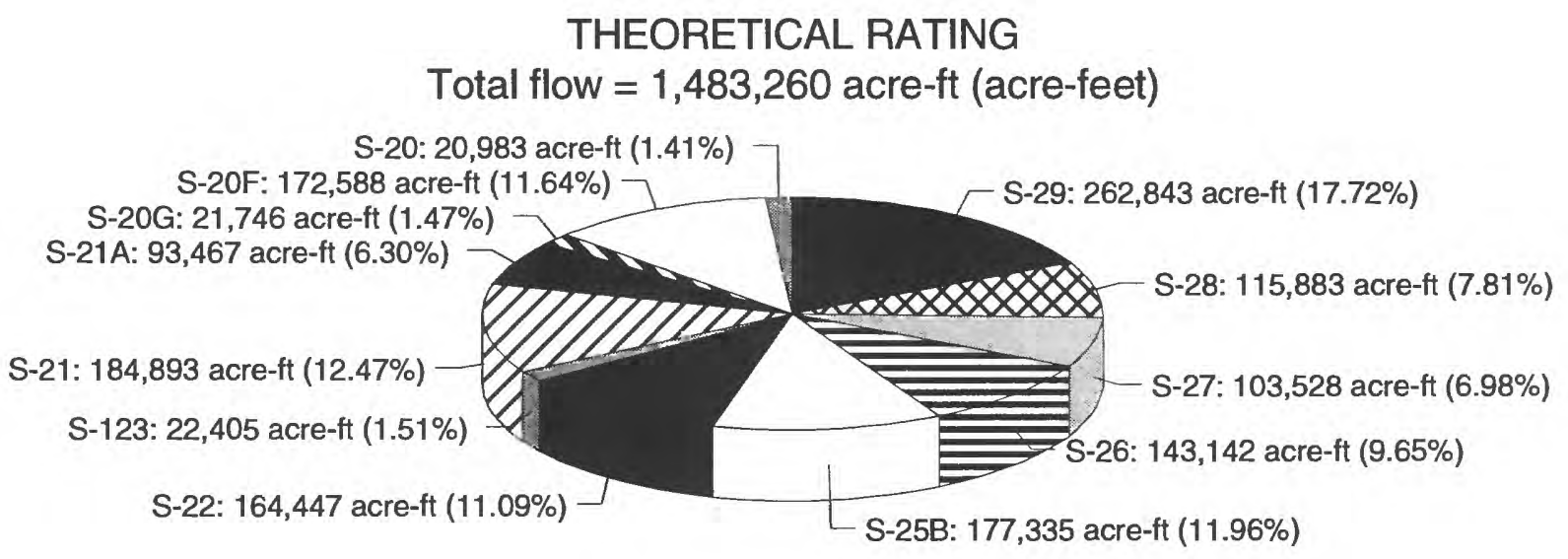

\section{COMPUTED RATING \\ Total flow $=1,534,770$ acre-ft (acre-feet)}

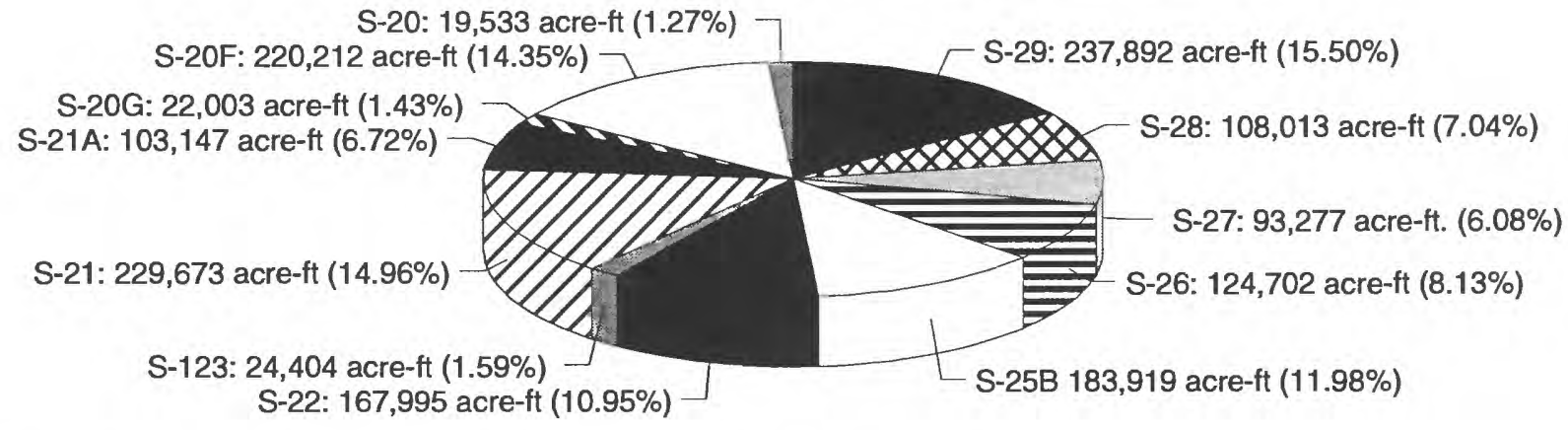

Figure 50. Cumulative theoretical and computed flows for 1994. 
flows are not used in the computation (the flow of freshwater to tidewater is the focus of interest). Structures G-58, G-93, S-25, and S-197 do not have remote telemetry, and consequently, discharges were not computed for them. The total flow volume is $1,483,260$ acre-ft for the theoretical-coefficient rating and $1,534,770$ acre- $\mathrm{ft}$ for the computed-coefficient rating in 1994. This 3.35-percent difference generally is less than the inherent errors in the field measurements and ratings. It should be noted that the theoretical-coefficient rating indicates 54.12 percent of flow from structure S-25B and those coastal structures north of S-25B; the computed-coefficient rating indicates only 48.73 percent of flow from these structures. This redistribution of flows may be significant.

Table 3 shows a summary of the statistics and discharge-coefficient ratings for submerged orifice flow developed for the Dade County coastal structures.

Table 3. Summary of discharge-coefficient ratings

\begin{tabular}{|c|c|c|c|c|c|}
\hline \multirow[b]{2}{*}{ Structure } & \multirow[b]{2}{*}{ Flow regime } & \multirow[b]{2}{*}{$\begin{array}{l}\text { Coefficient of } \\
\text { determination } \\
\left(R^{2}\right)\end{array}$} & \multirow[b]{2}{*}{$\begin{array}{l}\text { Standard } \\
\text { error of } \\
\text { coefficient }\end{array}$} & \multicolumn{2}{|c|}{$C=A x(X)^{B^{*}}$} \\
\hline & & & & $\mathbf{A}$ & B \\
\hline S-29 & $\begin{array}{l}\text { Submerged orifice flow } \\
\text { Submerged weir flow }\end{array}$ & $\begin{array}{l}0.9042 \\
0.9346\end{array}$ & $\begin{array}{l}0.0728 \\
0.0417\end{array}$ & $\begin{array}{l}0.5952 \\
0.8099\end{array}$ & -0.9228 \\
\hline G-58 & Submerged orifice flow & 0.7951 & 0.0234 & 0.1217 & 0.4042 \\
\hline S-28 & $\begin{array}{l}\text { Submerged orifice flow } \\
\text { Submerged weir flow }\end{array}$ & $\begin{array}{r}0.8610 \\
-4.9060\end{array}$ & $\begin{array}{l}0.0807 \\
0.0248\end{array}$ & $\begin{array}{l}0.6806 \\
0.6446\end{array}$ & -1.0620 \\
\hline S-27 & $\begin{array}{l}\text { Submerged orifice flow } \\
\text { Submerged weir flow }\end{array}$ & $\begin{array}{l}0.9715 \\
0.5592\end{array}$ & $\begin{array}{l}0.0475 \\
0.0334\end{array}$ & $\begin{array}{l}0.7136 \\
0.6802\end{array}$ & -1.1080 \\
\hline S-26 & $\begin{array}{l}\text { Submerged orifice flow } \\
\text { Submerged weir flow }\end{array}$ & $\begin{array}{l}0.9588 \\
0.7340\end{array}$ & $\begin{array}{l}0.0641 \\
0.0158\end{array}$ & $\begin{array}{l}0.7087 \\
0.7980\end{array}$ & -1.0720 \\
\hline$S-25 B$ & $\begin{array}{l}\text { Submerged orifice flow } \\
\text { Submerged weir flow }\end{array}$ & $\begin{array}{r}0.9642 \\
-0.9321\end{array}$ & $\begin{array}{l}0.0223 \\
0.0709\end{array}$ & $\begin{array}{l}0.7883 \\
0.5520\end{array}$ & -1.0470 \\
\hline S-25 & Submerged orifice flow & 0.9915 & 0.0117 & 0.1266 & 0.4921 \\
\hline G-93 & $\begin{array}{l}\text { Submerged orifice flow } \\
\text { Submerged weir flow }\end{array}$ & $\begin{array}{l}0.8066 \\
0.8447\end{array}$ & $\begin{array}{l}0.0703 \\
0.0432\end{array}$ & $\begin{array}{l}0.5980 \\
0.8630\end{array}$ & -0.8490 \\
\hline S-22 & $\begin{array}{l}\text { Submerged orifice flow } \\
\text { Submerged weir flow }\end{array}$ & $\begin{array}{l}0.9821 \\
0.1907\end{array}$ & $\begin{array}{l}0.0241 \\
0.0172\end{array}$ & $\begin{array}{l}0.7415 \\
1.0432\end{array}$ & -1.0270 \\
\hline$S-123$ & $\begin{array}{l}\text { Submerged orifice flow } \\
\text { Submerged weir flow }\end{array}$ & $\begin{array}{l}0.9825 \\
0.3313\end{array}$ & $\begin{array}{l}0.0257 \\
0.0271\end{array}$ & $\begin{array}{l}0.8159 \\
0.7159\end{array}$ & -1.0020 \\
\hline$S-21$ & $\begin{array}{l}\text { Submerged orifice flow } \\
\text { Submerged weir flow }\end{array}$ & $\begin{array}{r}0.9580 \\
-1.6749\end{array}$ & $\begin{array}{l}0.0910 \\
0.1355\end{array}$ & $\begin{array}{l}1.0070 \\
2.2880\end{array}$ & -1.1340 \\
\hline S-21A & $\begin{array}{l}\text { Submerged orifice flow } \\
\text { Submerged weir flow }\end{array}$ & $\begin{array}{r}0.9852 \\
-8.0263\end{array}$ & $\begin{array}{l}0.0429 \\
0.2508\end{array}$ & $\begin{array}{l}0.5952 \\
1.2104\end{array}$ & -0.9228 \\
\hline S-20G & $\begin{array}{l}\text { Submerged orifice flow } \\
\text { Submerged weir flow }\end{array}$ & $\begin{array}{l}0.8396 \\
0.1853\end{array}$ & $\begin{array}{l}0.0780 \\
0.0385\end{array}$ & $\begin{array}{l}0.5867 \\
0.3432\end{array}$ & -0.7786 \\
\hline$S-20 F$ & $\begin{array}{l}\text { Submerged orifice flow } \\
\text { Submerged weir flow }\end{array}$ & $\begin{array}{l}0.9883 \\
0.6278\end{array}$ & $\begin{array}{l}0.0252 \\
0.0253\end{array}$ & $\begin{array}{l}0.9591 \\
0.9474\end{array}$ & -1.0650 \\
\hline S-20 & $\begin{array}{l}\text { Submerged orifice flow } \\
\text { Submerged weir flow }\end{array}$ & $\begin{array}{l}0.9156 \\
0.0429\end{array}$ & $\begin{array}{l}0.0548 \\
0.0315\end{array}$ & $\begin{array}{l}0.6046 \\
0.3385\end{array}$ & -0.9374 \\
\hline S-197 & Submerged orifice flow & 0.0381 & 0.0833 & -0.2612 & 0.8128 \\
\hline
\end{tabular}

${ }^{*} C=$ flow coefficient, $X=h / G$ for submerged orifice flow at spillways, $X=h / H$ for submerged weir flow, and $X=$ $h / R$ for submerged orifice flow at culverts. 
The coefficient of determination $\left(\mathrm{R}^{2}\right)$, which is the standard error of coefficient (given in column 4), is a measure of the amount of the variation in the $\mathrm{Y}$-axis data explained by the $\mathrm{Y}$-axis data. When the best fit line is nearly horizontal, the spread is magnified by comparison with a near-zero variation of the $\mathrm{Y}$-axis data. Thus, the correlation coefficient can be very low even when there is little scatter in the field data. This is true in the case of submerged weir flow at structure S-22 and other sites.

As was shown in the previous sections for each coastal structure, the equation used by the SFWMD for the submerged orifice flow coefficient is $C_{g s}=0.75 /$ $(h / G)$. In table 3 , this would correspond to a value of $A$ $=0.75$ and $B=-1$. It can be seen that for submerged orifice flow that $A$ ranged from 0.5867 to 1.0070 and $B$ ranged from -1.1340 to -0.7786 . Most values of $A$ were about 0.75 , and most values of $B$ were about -1.0 .

The speed at which ADCP measurements can be taken was essential to the collection of data in rapidly changing conditions and slow, nonuniform velocities. The SACM and Price current meter had been used for older measurements and on an as-needed basis. A sufficiently wide range of conditions was measured in order to make useful computed-coefficient ratings for all of the coastal structures. The increased certainty in these computed-coefficient ratings will allow water managers to be more certain in their determination of flows to tidewater. The techniques developed in this study were applied to a recent study of the coastal structures in Broward and Palm Beach Counties.

\section{REFERENCES CITED}

Browder, J.A., Wang J.J., Tashiro, J., Colemann-Duffie, E., and Rosenthal, A., 1989, Documenting estuarine impacts of freshwater flow alterations and evaluating proposed remedies: Proceedings of the International Wetlands Symposium, Charleston, S.C., July 5-9, 1989, p. 177-196.
Collins, D.L., 1977, Computation of records of streamflow at control structures: U.S. Geological Survey WaterResources Investigations Report 77-71, 57 p.

Cooper, R.M., and Lane, J., 1987, An atlas of eastern Dade County surface-water management basins: West Palm Beach, South Florida Water Management District Technical Publication DRE-239, 97 p.

Helsel, D.R., and Hirsch, R.M., 1992, Statistical methods in water resources: New York, Elsevier Publishing Company, $522 \mathrm{p}$.

Kohout, F.A., and Leach, S.D., 1964, Salt-water movement caused by control-dam operation in the Snake Creek Canal, Miami, Florida: Florida Geological Survey Report of Investigations 24, pt. 4, 49 p.

Lipscomb, S.W., 1995, Quality assurance plan for discharge measurements using broadband Acoustic Doppler Current Profilers: U.S. Geological Survey Open-File Report 95-701, 7 p.

Merritt, M.L., 1995, Simulation of the water-table altitude in the Biscayne aquifer, southern Dade County, Florida, water years 1945-89: U.S. Geological Survey OpenFile Report 95-337, 88 p.

Otero, J. M., 1994, Computation of flow through water control structures: West Palm Beach, South Florida Water Management District Technical Publication WRE-328, $88 \mathrm{p}$.

RD Instruments, 1989, Acoustic Doppler Current Profilers-Principles of operation: A practical primer: San Diego, Calif., RD Instruments Publications, 36 p.

Simpson, M. R., and Oltmann, R.N., 1991, Discharge measurement system using an Acoustic Doppler Current Profiler with application to large rivers and estuaries: U.S. Geological Survey Open-File Report 91-487, 49 p.

U.S. Army Corps of Engineers, 1963, Typical spillway structure for central and southern Florida water-control project: Hydraulic Model Investigation Technical Report 2-633, 62 p.

U.S. Army Corps of Engineers, 1995, Central and southern Florida project for flood control and other purposes: Jacksonville, Fla., Master Water Control Manual, East Coast Canals, v. 5, p. 1-1 to 9-2, app. A-E. 
Appendix I. Flood discharge characteristics for the Dade County coastal structures

[SPF, Special Project Flood; SWF, submerged weir flow; SOF, submerged orifice flow; FWF, free weir flow; $\mathrm{ft}$, feet; $\mathrm{ft}^{3} / \mathrm{s}$, cubic feet per second. The SPF runoff is a structure specific value describing the amount of rainfall runoff associated with the 100-year storm]

\begin{tabular}{|c|c|c|c|c|c|c|c|c|}
\hline \multirow[b]{2}{*}{$\begin{array}{c}\text { Struc- } \\
\text { ture }\end{array}$} & \multicolumn{4}{|c|}{ Design } & \multicolumn{4}{|c|}{ Special Project Flood } \\
\hline & $\begin{array}{c}\text { Dis- } \\
\text { charge } \\
\text { rate } \\
\left(\mathrm{ft}^{3} / \mathrm{s}\right)\end{array}$ & $\begin{array}{l}\text { Head- } \\
\text { water } \\
\text { elevation } \\
\text { (ft) }\end{array}$ & $\begin{array}{c}\text { Tailwater } \\
\text { elevation } \\
\text { (ft) }\end{array}$ & $\begin{array}{l}\text { Flow } \\
\text { regime }\end{array}$ & $\begin{array}{c}\text { Dis- } \\
\text { charge } \\
\text { rate } \\
\left(\mathrm{ft}^{3} / \mathrm{s}\right)\end{array}$ & $\begin{array}{l}\text { Head- } \\
\text { water } \\
\text { elevation } \\
\quad(t)\end{array}$ & $\begin{array}{c}\text { Tailwater } \\
\text { elevation } \\
\text { (ft) }\end{array}$ & $\begin{array}{l}\text { Flow } \\
\text { regime }\end{array}$ \\
\hline G-58 & $\begin{array}{c}300 \\
60 \% \text { SPF }\end{array}$ & 1.6 & 1.1 & SWF & - & - & $\therefore$ & - \\
\hline G-93 & $\begin{array}{c}640 \\
40 \% \text { SPF }\end{array}$ & 4.5 & 3.0 & SOF & -- & - & -- & -- \\
\hline S-20 & $\begin{array}{c}450 \\
40 \% \text { SPF }\end{array}$ & 1.5 & 1.0 & SWF & $\begin{array}{c}750 \\
100 \% \text { SPF }\end{array}$ & 1.8 & 1.3 & SWF \\
\hline S-20F & $\begin{array}{c}2,900 \\
40 \% \text { SPF }\end{array}$ & 1.9 & 1.4 & SWF & $\begin{array}{c}4,900 \\
100 \% \text { SPF }\end{array}$ & 3.0 & 2.5 & SWF \\
\hline S-20G & $\begin{array}{c}900 \\
40 \% \text { SPF }\end{array}$ & 2.0 & 1.5 & SWF & $\begin{array}{c}1,700 \\
100 \% \text { SPF }\end{array}$ & 3.0 & 2.0 & SWF \\
\hline$S-21$ & $\begin{array}{c}2,560 \\
40 \% \text { SPF }\end{array}$ & 1.9 & 1.4 & SWF & $\begin{array}{c}4,300 \\
100 \% \text { SPF }\end{array}$ & 2.8 & 2.0 & SWF \\
\hline S-21A & $\begin{array}{c}1,330 \\
40 \% \text { SPF }\end{array}$ & 1.9 & 1.4 & SWF & $\begin{array}{c}2,500 \\
100 \% \text { SPF }\end{array}$ & 3.0 & 2.0 & SWF \\
\hline S-22 & $\begin{array}{c}1,915 \\
100 \% \text { SPF }\end{array}$ & 3.5 & 2.7 & SWF & -- & -- & - & - \\
\hline S-25 & 260 & 2.5 & - & FWF & $m$ & - & - & - \\
\hline S-25B & $\begin{array}{c}2,000 \\
100 \% \text { SPF }\end{array}$ & 4.4 & 4.1 & SWF & -- & -- & -- & -- \\
\hline S-26 & $\begin{array}{c}3,470 \\
100 \% \text { SPF }\end{array}$ & 4.4 & 3.9 & SWF & -. & -. & - & - \\
\hline S-27 & $\begin{array}{c}2,800 \\
75 \% \text { SPF }\end{array}$ & 3.2 & 3.0 & SWF & $\begin{array}{c}3,070 \\
100 \% \text { SPF }\end{array}$ & 3.2 & 2.7 & SWF \\
\hline S-28 & $\begin{array}{c}3,220 \\
100 \% \text { SPF }\end{array}$ & 2.3 & 1.8 & SWF & - & - & -. & - \\
\hline S-29 & $\begin{array}{c}4,780 \\
100 \% \text { SPF }\end{array}$ & 3.0 & 2.5 & SWF & -- & -- & -- & -- \\
\hline$S-123$ & $\begin{array}{c}2,300 \\
40 \% \text { SPF }\end{array}$ & 2.0 & 1.5 & SWF & $\begin{array}{c}5,000 \\
100 \% \text { SPF }\end{array}$ & 3.8 & 1.7 & SWF \\
\hline S-197 & $\begin{array}{c}2,400 \\
40 \% \text { SPF }\end{array}$ & 1.4 & .6 & SWF & -- & -- & -- & -- \\
\hline
\end{tabular}




\begin{tabular}{|c|c|c|c|c|c|c|c|c|c|c|c|c|c|c|c|c|c|c|c|}
\hline 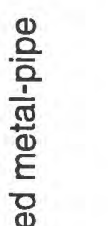 & & 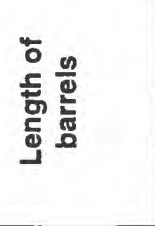 & 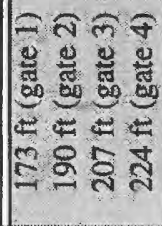 & $\ll$ & $\frac{\hbar}{z}$ & $\frac{\Sigma}{z}$ & $\frac{\mathbb{z}}{\mathbf{z}}$ & 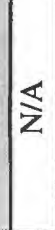 & $\frac{\$}{z}$ & 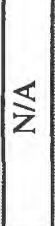 & 5 & $\frac{\xi}{z}$ & $\$$ & $\frac{1}{\mathrm{z}}$ & $\frac{3}{z}$ & $\leqslant$ & $\frac{1}{z}$ & 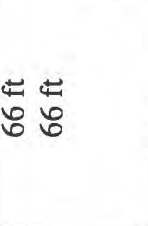 & \\
\hline $\begin{array}{l}\frac{\pi}{0} \\
\frac{0}{2} \\
\frac{2}{0} \\
0 \\
0 \\
\frac{1}{0} \\
\frac{c}{0} \\
\frac{0}{\frac{T}{3}} \\
\end{array}$ & & $\begin{array}{l}\frac{0}{0} \\
\frac{2}{00} \\
\frac{0}{0} \\
\frac{N}{0} \\
\frac{N}{n}\end{array}$ & 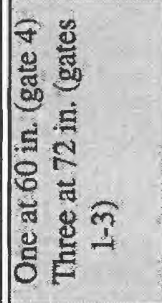 & $\overleftarrow{z}$ & $\frac{\$}{z}$ & $\leqslant$ & $\mathbb{z}$ & $\frac{\$}{z}$ & $\mathbb{z}$ & $\frac{\$}{z}$ & $\frac{\Phi}{\frac{\Phi}{3}}$ & 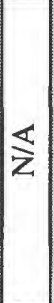 & $\frac{\$}{z}$ & $\leqslant$ & $\$$ & $\frac{\Sigma}{z}$ & $\frac{5}{\mathrm{z}}$ & $\begin{array}{l}\stackrel{\Xi}{\leftrightarrows} \\
\dot{\infty}\end{array}$ & \\
\hline $\begin{array}{l}\frac{\sigma}{\bar{c}} \\
\text { के } \\
\frac{0}{c}\end{array}$ & & है & $\forall$ & $\frac{\Sigma}{z}$ & $\frac{\xi}{z}$ & 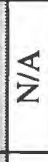 & $\leqslant$ & $\frac{\S}{z}$ & $\leqslant$ & $\ll$ & - & $\frac{\pi}{z}$ & $\frac{\$}{z}$ & $\leqslant$ & $\frac{\$}{\Sigma}$ & $\overleftarrow{z}$ & $\frac{\$}{z}$ & $m \varrho$ & \\
\hline 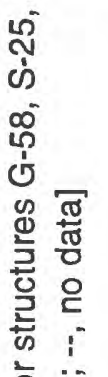 & & 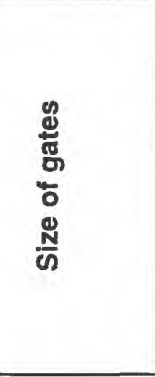 & 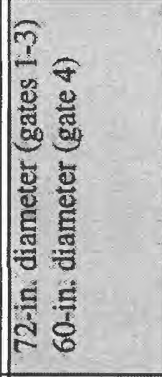 & 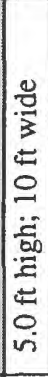 & 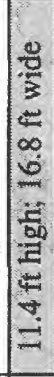 & 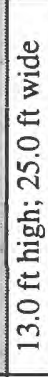 & 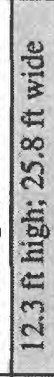 & 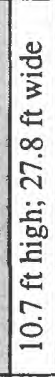 & 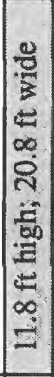 & 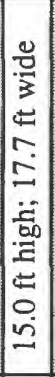 & 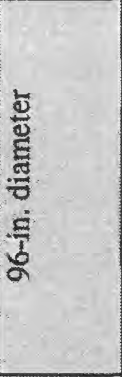 & 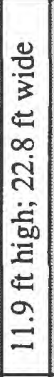 & 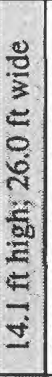 & 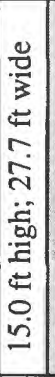 & 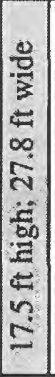 & 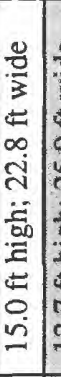 & 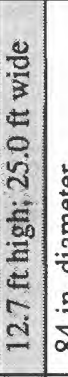 & 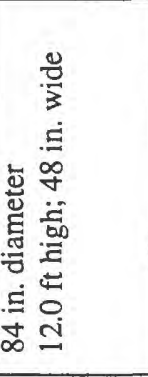 & \\
\hline 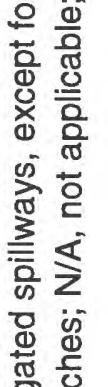 & & 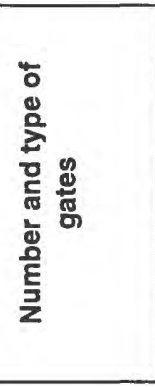 & 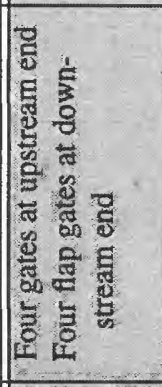 & 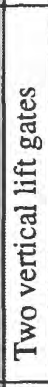 & 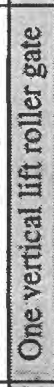 & 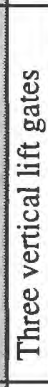 & 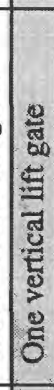 & 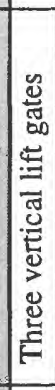 & 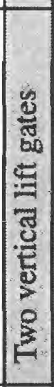 & 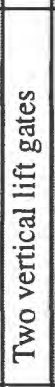 & 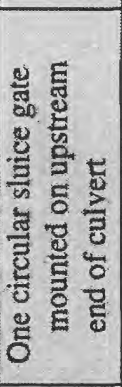 & 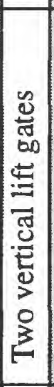 & 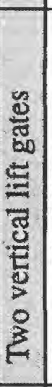 & 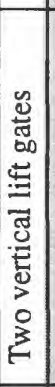 & 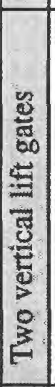 & 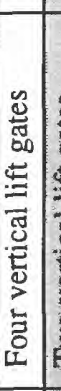 & 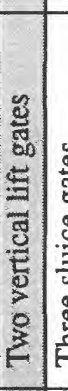 & 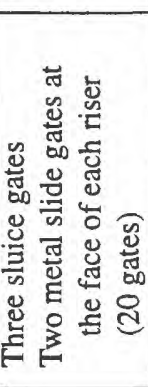 & \\
\hline . & \multicolumn{2}{|c|}{ 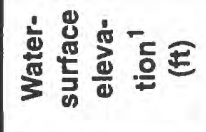 } & 8 & : & 웅 & $\stackrel{0}{i}$ & 웅 & $\begin{array}{l}0 \\
\infty\end{array}$ & 움 & $n$ & i & in & n? & $\stackrel{\circ}{+}$ & O & $\stackrel{0}{\circ}$ & $\stackrel{\circ}{\circ}$ & ir & ن. \\
\hline 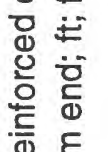 & \multicolumn{2}{|c|}{ 总 } & $\infty$ & $\stackrel{0}{\longrightarrow}$ & 웅 & $\stackrel{0}{\circ}$ & 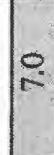 & in & 웅 & $\mid \begin{array}{l}\infty \\
\infty\end{array}$ & ñ & $\infty$ & 苾 & $\begin{array}{l}n \\
i n \\
i n\end{array}$ & $0_{0}^{\circ}$ & $\stackrel{0}{0}$ & \begin{tabular}{l|l}
0 & \\
0 &
\end{tabular} & $\begin{array}{l}n \\
n \\
n\end{array}$ & 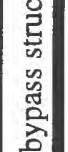 \\
\hline 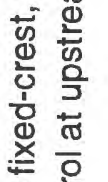 & \multirow{2}{*}{ 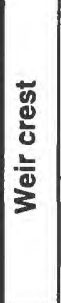 } & 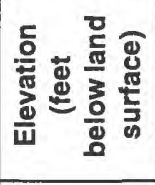 & 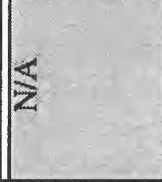 & $\stackrel{\infty}{-}$ & $\frac{\pi}{4}$ & $\stackrel{\circ}{\circ}$ & 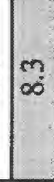 & no & $\stackrel{\infty}{\sim}$ & $\stackrel{0}{=}$ & $\frac{\$}{z}$ & $\stackrel{9}{r}$ & $\overrightarrow{0}$ & $\stackrel{\circ}{\stackrel{0}{=}}$ & 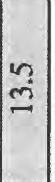 & $\stackrel{\circ}{=}$ & $\stackrel{m}{\sim}$ & $\frac{\$}{z}$ & 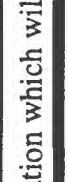 \\
\hline 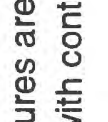 & & 志哥画 & $\mathbb{z}$ & 이 & 10 & $i 2$ & ฟ & $\bar{\infty}$ & 웅 & "̈ & 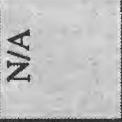 & $\exists$ & กี & 惡 & " & $\infty$ & in & $\overleftarrow{z}$ & 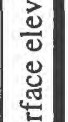 \\
\hline 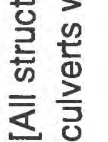 & & 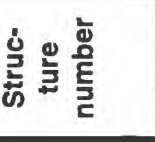 & $\begin{array}{l}0 \\
0 \\
0 \\
0\end{array}$ & ó & ๙ิ & 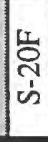 & \begin{tabular}{l}
$\dot{\delta}$ \\
\multirow{3}{}{} \\
$\dot{n}$
\end{tabular} & $\begin{array}{l}\bar{N} \\
\dot{s}\end{array}$ & 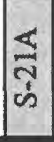 & $\begin{array}{l}\tilde{N} \\
\dot{n}\end{array}$ & $\begin{array}{l}\text { బิ } \\
\text { ம் }\end{array}$ & $\begin{array}{l}\infty \\
\tilde{y} \\
y \\
\dot{n}\end{array}$ & $\begin{array}{l}\text { ¿े } \\
\dot{n}\end{array}$ & \begin{tabular}{l}
\multirow{1}{*}{} \\
$\dot{n}$
\end{tabular} & 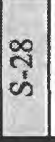 & 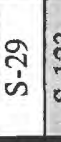 & 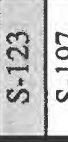 & $\frac{5}{\dot{s}}$ & 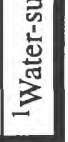 \\
\hline
\end{tabular}


Appendix III. Glossary of mathematical symbols used in report

\begin{tabular}{|c|c|}
\hline Symbol & Definition \\
\hline$A$ & Open area of the gate \\
\hline$b_{0}, b_{1}$ & Coefficients of the fitted regression \\
\hline$C_{c}$ & Submerged culvert coefficient \\
\hline$C_{g s}$ & Discharge coefficient for submerged orifice flow \\
\hline$C_{s}$ & Submergence coefficient relative to the function of $H / h$ \\
\hline$C_{w}$ & Discharge coefficient for free weir flow \\
\hline$C_{w s}$ & Discharge coefficient for submerged weir flow \\
\hline$D$ & Diameter of the culvert \\
\hline$e_{i}$ & Residuals \\
\hline$f^{-1}$ & Inverse of the selected transformation \\
\hline$g$ & Gravitational acceleration \\
\hline$G$ & Gate opening \\
\hline$h$ & Tailwater height above sill \\
\hline$H$ & Headwater height above sill \\
\hline K & Flow coefficient which accounts for entrance, friction, and exit losses \\
\hline$L$ & Length of gate sill \\
\hline$n$ & Manning's frictional factor \\
\hline$P$ & Wetted perimeter of the gate opening \\
\hline$Q$ & Discharge, in cubic feet per second \\
\hline$R$ & Hydraulic radius of the gate opening \\
\hline$v=Q / A$ & Mean flow velocity \\
\hline$Y_{i}$ & Response variable \\
\hline
\end{tabular}


